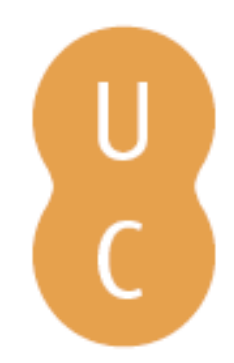

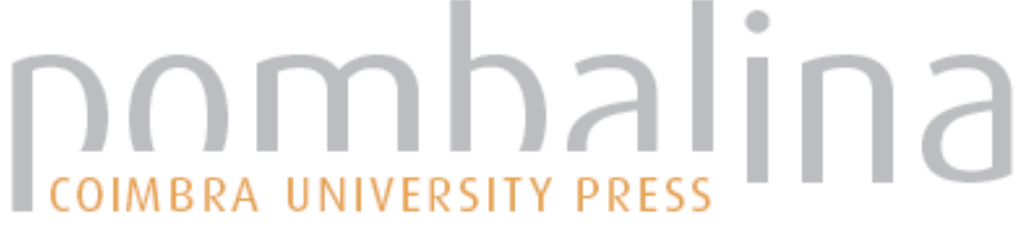

\section{Oração em louvor de todas as ciências e das grandes artes}

\author{
Autor(es): Pinto, António
}

Publicado por: Imprensa da Universidade de Coimbra

URL

persistente: URI:http://hdl.handle.net/10316.2/30837

DOI: $\quad$ DOI:http://dx.doi.org/10.14195/978-989-26-0448-0_6

Accessed : $\quad$ 26-Apr-2023 10:44:47

A navegação consulta e descarregamento dos títulos inseridos nas Bibliotecas Digitais UC Digitalis, UC Pombalina e UC Impactum, pressupõem a aceitação plena e sem reservas dos Termos e Condições de Uso destas Bibliotecas Digitais, disponíveis em https://digitalis.uc.pt/pt-pt/termos.

Conforme exposto nos referidos Termos e Condições de Uso, o descarregamento de títulos de acesso restrito requer uma licença válida de autorização devendo o utilizador aceder ao(s) documento(s) a partir de um endereço de IP da instituição detentora da supramencionada licença.

Ao utilizador é apenas permitido o descarregamento para uso pessoal, pelo que o emprego do(s) título(s) descarregado(s) para outro fim, designadamente comercial, carece de autorização do respetivo autor ou editor da obra.

Na medida em que todas as obras da UC Digitalis se encontram protegidas pelo Código do Direito de Autor e Direitos Conexos e demais legislação aplicável, toda a cópia, parcial ou total, deste documento, nos casos em que é legalmente admitida, deverá conter ou fazer-se acompanhar por este aviso.

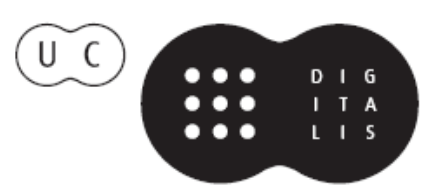




\section{Portvgaliae}

Monvmenta Neolatina

VOL. XI

ORAÇÕES

DE SAPIÊNCIA

$1548-1555$

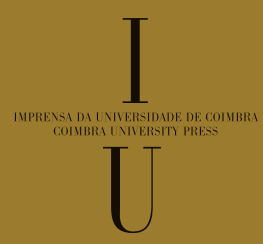




\section{ANTÓNIO PINTO}

\section{ORAÇÃO \\ EM LOUVOR DE TODAS AS CIÊNCIAS \\ E DAS GRANDES ARTES \\ 1 de Outubro de 1555}

Introdução, fixação do texto latino, tradução e notas

António Guimarães Pinto

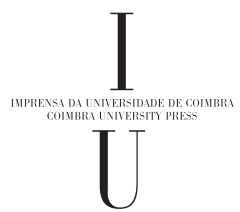


(Página deixada propositadamente em branco) 


\title{
INTRODUÇÃO
}

\author{
I \\ Quem foi (ou não foi) o António Pinto \\ autor da Oratio académica de $1555^{1}$
}

Uma das espécies mais raras da bibliografia portuguesa quinhentista em língua latina é constituída pelo opúsculo, in quarto, de 40 páginas não numeradas, publicado por João Álvares, em Coimbra, presumivelmente no ano de $1555 .^{2} \mathrm{Na}$ sua página de rosto inscreve-se: ORATIO de scientiarum omnium magnarumque artium laude ab Antonio Pinto habita apud Vniuersam Conimbricensem Academiam Kalendis Octobris Anno Domini 1555. Ad Illustrissimum Ioannem Ducem Daueiro. Conimbricae. Apud Ioannem Aluarem typographum Regium. Ou seja, em português: "Oração em louvor de todas as ciências e das artes elevadas pronunciada diante de toda a Academia Conimbricense por António Pinto no $1^{\circ}$ de Outubro do ano do Senhor de 1555. Dedicada ao ilustríssimo Senhor D. João, duque de Aveiro. Em Coimbra, nas oficinas de João Álvares, tipógrafo régio." O prefácio do autor, dirigido ao dedicatário, está datado de 15 de Outubro do mesmo ano de 1555 e encerra as pistas que nos permitiram, senão a identificação plena, pelo menos uma aproximação razoavelmente satisfatória, a este durante tanto tempo problemático António Pinto.

\footnotetext{
${ }^{1}$ Esta Introdução biográfica repete, nas suas linhas gerais e com algumas correcções e acrescentos, o texto do estudo do mesmo título, com o qual contribuímos para o volume colectivo de homenagem ao Doutor Braz Teixeira, intitulado Convergências e Afinidades, Lisboa, Centro de Estudos de Filosofia da Faculdade de Ciências Humanas da UCP e Centro de Filosofia da Universidade de Lisboa, 2008, pp. 339-367.

${ }^{2}$ Temos conhecimento directo do exemplar existente na Biblioteca Municipal do Porto, do qual nos servimos para a tradução e fixação do texto latino que irão ler-se nas páginas seguintes. A Biblioteca da Universidade de Coimbra possui outro exemplar desta raridade bibliográfica, em tudo idêntico ao espécime depositado na biblioteca portuense.
} 
De facto, os bibliógrafos em geral e os estudiosos do humanismo português em particular, ${ }^{3}$ ao tratarem do autor desta oração académica, ou dele fizeram um ser compósito que resulta da sobreposição de vários homónimos, ou o têm confundido com o António Pinto de maior nomeada nos fastos do século XVI, ou lhanamente reconheceram a impossibilidade de chegar a conclusões definitivas, em face da escassez ou carácter inconclusivo dos elementos disponíveis. ${ }^{4}$ A esta atitude de forçosa resignação tínhamos chegado, depois de alguns anos de baldadas investigações, quando o mero acaso nos deparou a imprevista identificação do nosso xará quinhentista.

Cuidamos que estas três tendências resultaram, no fundo, da maior ou menor crítica com que se têm lido e seguido as pistas apontadas pelo artigo que, na Biblioteca Lusitana, Barbosa Machado consagrou ao nome que nos ocupa, razão pela qual pedimos vénia para a sua transcrição, relativamente extensa:

"António Pinto. Natural de Lisboa, não somente insigne na faculdade de Leis nas quais recebendo o grau de Doutor na universidade de Coimbra, ilustrou o Senado de Lisboa com o lugar de desembargador dos agravos, de que tomou posse a 3 de Dezembro de 1575, mas na elegância e pureza com que falava a língua latina, e na poesia de todo o género como entre os professores mais célebres desta arte o numera com grande louvor Pedro Sanches na "Epistola ad Ignatium Moralium de Poet. Latin." [cita os três primeiros versos do trecho que Sanches consagra a António Pinto, que veremos na totalidade mais à frente] Por estes singulares dotes o elegeu por seu secretário o insigne herói Lourenço Pires de Távora, quando foi por embaixador a Roma, e tanto confiou da sua prudente actividade, que lhe cometeu no ano de 1561 a grave incumbência de partir ao Preste João com cartas de Pio IV e del-rei D. Sebastião para que o imperador daquele vasto império mandasse seus embaixadores que assistissem ao Concílio Tridentino. O mesmo lugar de secretário exercitou com D. Fernando de Meneses embaixador na cúria recitando no ano de 1566 a oração obediencial em nome del-rei D. Sebastião na presença de S. Pio V

\footnotetext{
${ }^{3}$ Especial menção merece Francisco José Avelar Nobre, que, como dissertação para licenciatura em Filologia Clássica, apresentou à Faculdade de Letras da Universidade de Coimbra, em 1962, o trabalho dactilografado A oração laudatória de todas as ciências e das belas-artes de António Pinto. A transcrição do texto latino e a versão portuguesa do mesmo são precedidas de uma laboriosa introdução, em que o autor, depois de nos apresentar o resultado dos seus diligentes esforços, com a verdadeira humildade dos sábios confessa: "Devemos desde já prevenir de que, à face da documentação encontrada, nos foi impossível atribuir a esse jurisconsulto a autoria da Oração, como o fez, categoricamente, Diogo Barbosa Machado, na Biblioteca Lusitana. Mas também nos pareceu arrojado atribuíla, sem provas bastantes, a qualquer dos vários indivíduos que, com este nome, floresceram nas letras, no referido século. A dúvida, deste modo, persiste e fomos incapazes de transformá-la na certeza de que precisávamos, do que nos penitenciámos." O. c., p. 4.

${ }^{4}$ Posição do nosso Mestre e Amigo Professor Américo da Costa Ramalho, sintetizada no artigo que consagra a António Pinto na última edição da enciclopédia VERBO. Do mesmo autor, veja-se também Camões no seu tempo e no nosso, Coimbra, Almedina, 1992, pp. 21-23 e 199 .
} 
novamente sublimado ao trono de S. Pedro, a qual imprimiu em Roma com este título: "Oratio ad Pium V [...]"; "Oratio de scientiarum [...]"; "Regis Sebastiani infelix bellum, et obitus", poema em verso heróico que se não imprimiu por não querer riscar a palavra Fatum que a indiscreta crítica do censor que examinou a obra mandava tirar; "Cartas originais sendo residente em Roma desde o ano de 1562 até 1572 para Lourenço Pires de Távora”. Manuscrito conservado na livraria do excelentíssimo marquês de Abrantes."

Pensamos que Barbosa Machado adjudica a um único António Pinto elementos biográficos procedentes de, pelo menos, quatro personagens do mesmo nome: 1) o poeta latino retratado na epístola de Pedro Sanches; 2) o que no ano de 1561 recebeu a incumbência de partir ao Preste João com cartas de Pio IV e de D. Sebastião; 3) o doutor canonista, secretário de embaixada e agente, durante longos anos, da corte portuguesa em Roma, autor da oração obediencial ao papa Pio V; 4) o autor da Oratio pronunciada em Coimbra, em 1555.

De cada um deles nos ocuparemos agora em separado, no sentido de, também por exclusão de partes, chegarmos à determinação da identidade deste último.

1. Na célebre resenha e crítica que Pedro Sanches, sob forma de carta a Inácio de Morais, faz dos portugueses seus contemporâneos que se aplicaram à poesia latina, lemos, nas páginas 22 e 23 do tomo primeiro do Corpus illustrium poetarum Lusitanorum, qui Latine scripserunt, nunc primum in lucem editum ab Antonio dos Reys, Lisboa, Typis regalibus Sylvianis, Regiaeque Academiae, 1745:

Pintus adest alter, Pintus, cui carmina saepe Plura dedit Paean, quam praebent litora conchas, Quam fert Hybla thymum, quam Ladon uoluit arenas :

Et quamuis multos Regis perductus in aulam Ingenuos docuit iuuenes, sudauit et alsit Attamen ille fame tabescit, penula semper Ex humeris detrita cadit, toga pandit hiatus, Et uetus insidit ueneranda in fronte galerus; (Ne temere haec dicas te solum incommoda ferre) At bonus est, doctus, simplex, uir candidus, ut si Quisquam alius sancte nostro nunc degit in aeuo.

Ou seja, na nossa língua:

"Presente está um segundo Pinto, a quem amiúde Apolo mais carmes concedeu do que conchas oferecem as praias, do que tomilho produz o Hibla, do que areias o rio Ladão rola: e, ainda que, colocado na corte do rei, muitos moços nobres tenha ensinado e suado tenha e sofrido frios, não obstante definha de fome, a usada capa anda sempre a cair-lhe dos ombros, a toga abre-se em rasgões e sobre a veneranda fronte assenta um chapéu velho: para que não te atrevas a dizer que és o único a 
suportar estes incómodos. Mas é varão bom, douto, singelo e franco, igual a qualquer outro que hoje viva santamente na nossa época.»

A leitura deste retrato, além de imediatamente nos evocar aqueles versos de Cesário Verde, que todo o latinista português tão bem conhece:

"Dó da miséria!...Compaixão de mim!..."

E, nas esquinas, calvo, eterno, sem repouso,

Pede-me sempre esmola um homenzinho idoso,

Meu velho professor nas aulas de latim! ${ }^{5}$

sublinha, por um lado, a fecundidade do estro desta mofina personagem, e, por outro, informa-nos do quão pouco lucrativa era a actividade profissional deste mestre que, consoante esclarece uma nota do compilador, sucedera a António Pinheiro como professor dos moços fidalgos com residência na corte ("Antonius Pintus, post Antonium Pinheiro, magister Aulicorum Puerorum, vulgo: moços fidalgos"). Ora, sabe-se que António Pinheiro foi escolhido para esta função em 1540-1541, logo após o seu regresso ao reino, depois dos anos de estudo em Paris, cargo que desempenhou antes de ser nomeado preceptor do príncipe herdeiro D. João (nascido em 1537 e morto em 1554). Da produção copiosa da musa latina deste António Pinto só temos conhecimento de duas composições, manuscritas, que se encontram no Códice 8920 da BNL, fólios 85 (recto e verso) e 96 (recto e verso), e com os seguintes encabeçamentos em português: Versos de António Pinto, estando preso na cadea, sobre ũas palavras que disse a um desembargador e Outros versos de António Pinto sobela mesma prisão. ${ }^{6}$ De ambas daremos, no Apêndice $1^{\circ}$, o texto latino e a versão portuguesa, podendo desde já adiantar que a inspiração deste poeta não nos parece que corresse parelhas com a torrencial abundância que Sanches lhe atribui. ${ }^{7}$ Para o fim meramente histórico que aqui perseguimos, interessa-nos

5 O Livro de Cesário Verde, "Cristalizações. III. Ao Gás".

${ }^{6}$ Em 1980 publicou Christopher L. Lund, com o título Anedotas Portuguesas e Memórias Biográficas da Corte Quinhentista, Almedina, Coimbra, a reprodução diplomática de um manuscrito, presumivelmente seiscentista, existente na Biblioteca do Congresso dos EUA com a cota P-129. Nele se enfeixam "histórias e ditos galantes que se disseram no paço" e se promete, no estilo de slogan caro aos compatriotas do editor: "matéria biobibliográfica inédita de Luís de Camões e outros escritores do século XVI." Ora, nas pp. 171-172, menciona-se um "António Pinto, homem de notável habilidade. A ele só na poesia reconhecia Luís de Camões ũa certa excelência, de maneira que em sua presença não ousava muitas vezes fazer versos. Na prosa levava a todos os do tempo ũa ventagem tão conhecida / que por ordem del-rei lhe estava já encomendado continuar as Décadas de João de Barros na história da Índia, a qual obra lhe não chegou a dar princípio porque o tirou deste mundo a morte antecipada." Infelizmente não possuímos quaisquer suportes documentais que nos permitam conceder grande crédito a esta notícia.

${ }^{7}$ Não nos parece que estas duas composições consintam atribuir ao autor mais méritos que os de um paciente e memorioso ensamblador de versos e prosa alheios. À primeira leitura 
colher os elementos cronológicos que estes versos oferecem e que se cifram em, em primeiro lugar, o autor, no verso 4 do segundo poema, se referir à sua idade provecta (senis ... senem), e, em segundo lugar, podermos datar a composição desta súplica metrificada, tal como a da anterior, numa data que se situa entre finais de 1560 e meados de 1569, uma vez que ambas estão endereçadas aos membros da Casa da Suplicação e à personagem que por inerência de cargo estava à sua frente, o regedor de justiça, aqui bem identificado como Lourenço da Silva. Ora, é bem sabido que o $13^{\circ}$ regedor de justiça, comendador de Messejana e alcaide-mor de Lagos, Lourenço da Silva, foi nomeado para o desempenho desta importante função por alvará de 16 de Novembro de 1560, vindo a ser substituído quase nove anos depois por D. Luís Pereira de Castro, provido por alvará de 23 de Julho de 1569. ${ }^{8}$

2. Na Biblioteca da Ajuda, com a cota 49-IX-42, encontra-se um livro manuscrito, intitulado Livro de cartas do senhor Lourenço Pires de Távora estando em Roma por Embaixador del-rei D. Sebastião para o mesmo rei e para a rainha Dona Catarina, obra que supomos ter sido amplamente utilizada pelos compiladores do Corpo Diplomático Português. Das cartas diplomáticas que a compõem, a primeira é datada de 16 de Junho de 1559, imediatamente após a chegada de Pires de Távora a Roma, ${ }^{9}$ na penúltima indica o dia 23 de Abril de 1562 como o da saída definitiva da Cidade Eterna $^{10}$ e a última foi escrita de Madrid, a 3 de Junho do mesmo ano de $1562 .{ }^{11}$ No correr desta epistolografia diplomática, respigamos as seguintes referências a este segundo António Pinto, ex-cativo no Egipto e homem com todas as traças de agente duplo:

"Também levará este correo ũa carta de um António Pinto que está no Cairo e foi cativo com João de Lisboa" (Roma, 21 de Julho de 1559); ${ }^{12}$

"António Pinto e Bastião, criado, que foram cativos com João de Lisboa, estão em Messina segundo tenho por aviso de um amigo honrado daquela cidade [...] e consigo os mais portugueses que estavam cativos no Cairo, que creo chegam ao

se nos depararam várias citações directas de Virgílio, Juvenal e Cícero, além de constantes ecos de toadas conhecidas, estando nós convictos de que uma análise crítica um pouquinho mais detençosa (que o versista não merece) nos permitiria reduzir estes poemas à condição de centões.

8 Maria do Rosário Azevedo Cruz, As Regências na Menoridade de D. Sebastião, Lisboa, INCM, 1992, $1^{\circ}$ volume, pp. 136-137; Anselmo Braamcamp Freire, Brasões da Sala de Sintra, Coimbra, Imprensa da Universidade, 1927, II, pp. 63-64.

9 O. c., f. $1 \mathrm{~V}^{\mathrm{o}}$. Em todas as transcrições de textos antigos em português actualizámos a ortografia, com respeito porém por todas as particularidades fonéticas próprias do português do século XVI.

$$
\begin{aligned}
& { }^{10} \text { O. c., f. } 321 . \\
& { }^{11} \text { O. c., f. } 322 . \\
& { }^{12} \text { O. c., f. } 6 \mathrm{v}^{\mathrm{o}} .
\end{aligned}
$$


número de trinta ou trinta e tantos, por outros tantos mouros ou turcos comprados nestas partes" (Roma, 13 de Outubro de 1560); ${ }^{13}$

"António Pinto é muito prático nas cousas do Cairo e com sua informação tenho muita clareza do que ali se deve fazer em serviço de Vossa Alteza. Ordenei que ficasse nesta minha casa esperando pela reposta de Vossa Alteza ao negócio destes cativos para ele ser o que leve os mouros ou turcos que se hão-de comprar, e como quem é tão prático tornar ao Cairo a acabar de concluir o livramento dos seus companheiros e fazê-los desembaraçar de todo e embarcar até Messina ou Veneza. [...] O dito António Pinto isto feito se quer ir do Cairo por terra à Índia por via de Hierusalém, Damasco e Alepo" (Roma, 9 de Novembro de 1560); ${ }^{14}$

"Enformei-me largamente de António Pinto que veo do Cairo da vida, do hábito, da conversação, do modo, do trato que o dito Bicudo tinha naquela cidade. [...] Por este António Pinto do Cairo entendi e deve saber pela liberdade que naquela cidade tinha e nela usar ofício de corretor" (Roma, Novembro de 1560); ${ }^{15}$

"Não achei outra [pessoa] mais suficiente que António Pinto que os dias passados veo do Cairo ao resgate dos cativos portugueses seus companheiros, e que atégora aqui esteve mal desposto, acha-se já bem oferece-se à dita jornada ${ }^{16}$ dizendo-lhe eu será serviço de Vossa Alteza e em certo modo mandando-se-lhe de sua parte ele se mostra esforçado e contente pera o efeito, e cuido que o fará muito bem porque determina, sendo escravo do Turco, inda que forro, e tendo os deste título grandes privilégios, pedir ao baxá do Cairo salvo-conduto pera ir ao Abexim dizendo ser lá morto um seu irmão, da herança do qual espera recadar dinheiro, afirma, e eu creio, que lhe darão facilmente o dito salvo-conduto, e que poderá ir e trazer em sua companhia duas ou três pessoas em trajos dissimulados, quais o Preste ordenou que venham pera se acharem no Concílio, e quando no salvo-conduto houvesse dificuldade, terá modo pela dita via passar por meo de cristãos do Abexim, e pela mesma virem os que o Preste mandar em trajos de romeiros que vem a Hierusalém, e postos em Alexandria facilmente se embarcarão pera cá” (Roma, 12 de Agosto de 1561); ${ }^{17}$

"Quis Deus e ordenou a ventura não se achasse nesta corte outra pessoa mais suficiente pera poder fazer esta viagem que o honrado António Pinto português experimentado em negócios e prático nas cousas do Cairo" (Roma, 23 de Agosto de 1561). ${ }^{18}$

13 O. c., f. 127.

${ }^{14}$ O. c., ff. $137 \mathrm{v}^{\mathrm{o}}-138$.

15 O. c., ff. 146 e 147.

${ }^{16}$ Refere-se ao envio de alguém ao Preste João com a incumbência de trazer um representante seu ao Concílio de Trento.

17 O. c., f. $270-270 \mathrm{v}^{\circ}$.

18 O. c., f. $281 \mathrm{v}^{\mathrm{o}}$ : daqui a 283 pode ler-se a cópia da carta que o embaixador Távora escreveu ao Preste João, de que António Pinto deveria ser o portador. Nos ff. 283-285 v ${ }^{\circ}$ 
3. Ocupar-nos-emos agora do António Pinto mais afamado, a vários títulos, do século XVI, e que, por uma irritante coincidência de circunstâncias, à primeira vista parecia reunir em si o maior número de probabilidades para ser inculcado como o autor da Oratio latina de 1555. Possuímos documentação não escassa sobre o percurso biográfico deste Doutor António Pinto, que tentaremos traçar de forma sumária e ajustada ao nosso intento.

Tanto a documentação coeva como as informações dos genealogistas coincidem em dar-nos o Doutor António Pinto como natural da vila transmontana do Mogadouro e como sobrinho do conhecido monge jerónimo frei Diogo de Murça, reformador da Congregação de Santa Cruz de Coimbra e um dos primeiros e mais activos reitores da universidade conimbricense. Felgueiras Gayo, no título dos Senhores de Felgueiras, apresenta-nos a linhagem do nosso autor, que extractaremos apenas nos itens que interessam ao nosso escopo:

«7. Gonçalo Vaz Pinto, Senhor de Ferreiros de Tendais, teve:

8. Nuno Álvares Pereira, casou com Dona Isabel Pereira de Sampaio, tiveram:

9. Dona Maria Pinto Pereira, casou em Murça com Gonçalo Vaz Guedes, ${ }^{19}$ tiveram: 10. Frei Diogo de Murça;

11. Francisco Vaz Guedes ${ }^{20}$ casou no Mogadouro com Maria Valência, filha de Francisco Valência, fidalgo de Samora, e de sua mulher Maria de Burgos, o qual Francisco Valência tinha vindo para Portugal por causa da Excelente Senhora; tiveram:

12. António Pinto. Foi agente em Roma, mestre-escola da sé de Lamego, chantre da de Viseu, deão da de Coimbra e do conselho de Estado em Madrid e embaixador ao império.» ${ }^{21}$

copia-se o breve em latim que o papa enviava ao soberano etíope pelo mesmo portador. Finalmente, os ff. 286-289 $\mathrm{v}^{\circ}$ transcrevem a instrução que o embaixador entregou a António Pinto "pera o que havia de fazer no Abexim".

${ }^{19}$ Apesar de nem Felgueiras Gayo nem os demais linhagistas que consultámos a ele se referirem, teve frei Diogo de Murça um cunhado de nome idêntico ao do pai, o licenciado Gonçalo Vaz, do qual encontrámos referências na correspondência travada entre o monge hieronimita e o rei D. João III: "O licenciado Gonçalo Vaz, meu cunhado, que serviu Vossa Alteza na comarca de Miranda do Doiro, é espedido da dita corregedoria " (carta de frei Diogo, datada do Mosteiro da Costa, Guimarães, 25 de Março de 1542); "frei Diogo, vi a carta que me escrevestes sobre o licenciado Gonçalo Vaz, vosso cunhado, e pela boa enformação que dele tenho e por vosso respeito hei por bem de me servir dele no desembargo da Relação de Braga com aquele ordenado que tem os outros desembargadores dela e lhe escrevo sobre isso" (minuta de carta de D. João III a frei Diogo de Murça, de 1542). Apud Mário Brandão, Coimbra e D. António Rei de Portugal. A educação de D. António, 1º tomo, Coimbra, 1939, pp. 145 e 153.

${ }^{20}$ Por uma questão prática colocámos frei Diogo de Murça antes do irmão Francisco Vaz Guedes, que era o morgado da casa de seus pais.

${ }^{21}$ Felgueiras Gayo, Nobiliário de Famílias de Portugal, Braga, Carvalhos de Basto, 1989, $8^{\circ}$ tomo, pp. 287-288. As informações sobre os cargos de António Pinto não nos parecem totalmente correctas, como se verá. 
Para que não restem dúvidas sobre o parentesco entre frei Diogo e António Pinto, baste-nos citar o seguinte passo de uma carta do embaixador Lourenço Pires de Távora para o rei: "e porque eles porventura darão outra informação a Vossa Alteza por o Doctor António Pinto sobrinho de frei Diogo de Murça ser meu secretário e cuidarem que com esse favor alcança justiça [...]."22 Também a heráldica nos leva à inclusão do nosso António Pinto nesta ilustre família transmontana, porquanto sabemos que usava no seu brasão de armas "cinco flores de lis e cinco crescentes", ou seja, as tradicionais armas de Guedes e Pintos. ${ }^{23}$

Apesar da luzida nobreza que o esmaltava pelo lado paterno, ${ }^{24}$ sobre ele caiu a balda de cristão-novo pelo lado da mãe. De facto, o linhagista acabado de citar, sentiu-se obrigado a escrever em nota:

"Alguns quiseram infamar esta família dizendo que Maria Valência era filha de um médico de Mogadouro, porém de uma memória que vi se mostra o contrário, pois havendo no Mogadouro naquele tempo duas Marias Valências a mulher deste Francisco Vaz era diferente da outra, o que se mostrava por inquirição do Santo Ofício e serem seus filhos e netos clérigos e religiosos.» 25

Além de não deixarem de nos causar estranheza tantas coincidências de nomes estrangeiros numa localidade sertaneja como o Mogadouro, o facto é que outros indícios apontam na mesma direcção do sangue hebraico da progenitora do Doutor António Pinto.

O primeiro é a informação de Monsenhor André Calligari, que em correspondência enviada, em 1575, da Nunciatura de Lisboa para o cardeal Como, secretário de Estado do papa Gregório XIII, diz de Pinto "ser cristão-novo e tão novo que o seu avô materno, natural do Mogadouro, foi queimado por impenitente." 26

Também um outro testemunho autorizado nos parece apontar sem margem para dúvidas neste sentido: o de D. Álvaro de Castro, sucessor de Lourenço Pires

${ }^{22}$ Livro de cartas do senhor Lourenço Pires de Távora, o. c., f. 79. Carta de Roma, datada de 16 de Maio de 1560.

23 Ver artigo de Charles-Martial De Witte, "Saint Charles Borromée et la couronne de Portugal", Boletim Internacional de Bibliografia Luso-Brasileira, 7, n 1, Janeiro-Março de 1966, pp. 114-156, onde, a propósito de uma carta de António Pinto, escrita de Roma a 25 de Fevereiro de 1574, o douto investigador belga, pouco versado em brasonística lusitana, cuida ver naqueles lises as armas dos Farnésios..

${ }^{24}$ Foi inclusivamente condiscípulo de D. Duarte, filho natural de D. João III, e de D. António, futuro Prior do Crato, nos estudos que estes régios pupilos frequentaram no Colégio da Costa, em Guimarães. Vide Mário Brandão, Coimbra e D. António, o. c., pp. 15, 16, 138, 141 e 142, onde se transcrevem cartas onde é designado como o "Antoninho, sobrinho de frei Diogo."

25 Felgueiras Gayo, obra e volume citados, p. 288.

${ }^{26}$ Apud José de Castro, Bragança e Miranda (Bispado), I, Porto, Tipografia Porto Médico Ld ${ }^{\text {. }}$, 1946, p.136. O texto original desta informação encontra-se, segundo este autor, no Arquivo Secreto do Vaticano, Nunziatura di Portogallo, vol. 3, f. 112. 
de Távora na embaixada romana, ${ }^{27}$ o qual, em carta ao rei de 11 de Setembro de 1562, escreve o seguinte:

"[...] pola qual [carta] entendi a ordem que havia por seu serviço que tivesse contra o requerimento com os cristãos-novos de seu reino trazem com Sua Santidade: creo que já Vossa Alteza terá sabido o que sobreste caso fez António Pinto, o qual pôs isto em tais termos, que atégora se não falou mais neste negócio, e tenho sabido que stá o procurador desta gente de todo desesperado, por onde Vossa Alteza pode ver quão diferente informação teve de António Pinto, pois me mandava que o não fizesse sabedor desta matéria tendo-lhe ele feito todo serviço, que eu e qualquer outro menistro pudera fazer, e afirmo a Vossa Alteza que o que tenho conhecido deste homem é ter calidades pera se fiar muito dele, e ser ele este, e filho dum homem honrado deve bastar pera satisfazer a raça que tem, que nemo sine crimine uiuit.» 28

Finalmente, certa posição tomada por António Pinto nos parece nascer da consciência do sangue "embaraçoso" que os seus avoengos maternos lhe legaram. Com efeito, tratando-se em 1591, em Madrid, da aprovação dos Estatutos da Universidade de Coimbra, cuja revisão final correra a cargo dos membros do Conselho de Portugal Doutor António Pinto, Doutor Pedro Barbosa e D. Jorge de Ataíde, este último, ao enviar a D. Cristóvão de Moura o texto definitivo, juntamente com o alvará de confirmação que o rei deveria assinar, acompanha-os de uma carta em que, a certa altura, escreve:

«Este livro foi visto pelos Doutores Pedro Barbosa e António Pinto e por mim, e se emendaram todas as cousas que nos pareceu a todos em conformidade. Só em duas cousas discordou António Pinto de nós. A primeira que diz o Estatuto antigo, que sempre houve, que os capelães da universidade sejam de limpa geração e sem raça. Ele queria que se tirasse isso, e que ficasse em lei mental, e que não ficasse em escrito. [...] Também diz o Estatuto Novo que as conesias doutorais e magistrais que se hão-de dar por oposição em Coimbra se não possam apresentar em elas pessoas que tenham raça. A isto contradisse o mesmo Doutor.» ${ }^{29}$

\footnotetext{
${ }^{27}$ No período que nos interessa (1559-1588) as funções de embaixador português em Roma foram desempenhadas por Lourenço Pires de Távora (1559-1562); D. Álvaro de Castro (1562-1564); D. Fernando de Meneses (1566-1567); de novo D. Álvaro de Castro (1567-1568); D. João Telo de Meneses (1569); João Gomes da Silva (1578-1579). Como veremos, ou na qualidade de secretário dos embaixadores ou como agente do governo português, Pinto manter-se-á em Roma de 1559 até 1588, sendo neste ano substituído no cargo pelo sobrinho Francisco Vaz Pinto. Facilmente se depreende que o funcionamento da embaixada e a expedição dos negócios com a Cúria, na prática dependiam quase exclusivamente do Doutor Pinto. Veja-se Fortunato de Almeida, História da Igreja em Portugal. Nova edição preparada e dirigida por Damião Peres, Porto-Lisboa, Livraria Civilização, $2^{\circ}$ tomo, pp. 590-591.

${ }^{28}$ Corpo Diplomático Português, tomo 10, p. 20.

29 Carta de D. Jorge de Ataíde a D. Cristóvão de Moura, Madrid, 17 de Novembro de 1591, in Compêndio Histórico do Estado da Universidade de Coimbra no Tempo da Invasão dos Denominados Jesuítas, 1771, Lisboa, Régia Oficina Tipográfica, 1771, pp. 51-52. A vesânia antijesuítica dos autores do Compêndio cegou-os para este significativo detalhe da carta
} 
Ora, atendo-nos aos informes fornecidos pelos arquivos da academia conimbricense, verificamos que, em 26 de Junho de 1549, António Pinto, natural do Mogadouro, provou a frequência de três cursos de cânones, iniciada em Outubro de 1546, e de seis meses de vacações (Autos e graus, tomo 3, f. 40); fez exame para bacharel na mencionada faculdade em 23 de Julho de 1550 (Autos e graus, tomo 4, livro 1, f. 37 $\mathrm{v}^{\circ}$ ); e, no mesmo dia, recebeu o grau respectivo (códice e livro citados, f. 38). ${ }^{30} \mathrm{Em}$ 30 de Outubro de 1557 o conselho da universidade escutou e deu provimento a uma "petição do doutor António Pinto em que dezia que despois de bacharel em cânones nesta universidade esteve por muitos anos em Itália e algum tempo deles na universidade de Bolonha, na qual recebeu o grau de doutor na dita faculdade como constava da sua carta do dito grau que apresentava e por desejar ser incorporado nesta universidade onde recebeu o primeiro grau.»31

Por esta altura, já o Doutor António Pinto iniciara a incrível acumulação de cargos eclesiásticos, seguramente sem o ónus do pastoreio da grei cristã, que sobre ele, juntamente com ofícios civis, choveriam de uma forma incessante e copiosa e parecem demonstrar que o sangue hebreu não o desmerecia aos olhos dos poderosos de Portugal e de Roma. ${ }^{32}$

Em 23 de Junho de 1559 Lourenço Pires de Távora, acabado de chegar à cidade papal, escreve para o rei português (mais exactamente, a rainha Dona Catarina, então regente na menoridade do neto D. Sebastião):

"Entre os homens que achei nesta corte para me poderem servir de secretário escolhi o doctor António Pinto que aqui era vindo ao negócio da dispensação da filha de Luís Álvares de Távora e por ele ser suficiente por letras e habilidade e por ser da nossa criação me parece poderei mui bem confiar dele, o que se deve fiar e isto farei enquanto ele puder e a mim não for necessário mudar deste prepósito.»33

A conselho do governo português, Pinto não acompanha Távora no seu regresso a Portugal e irá desempenhar junto do novo embaixador D. Álvaro de Castro as funções para que o talhavam "a prática que dos negócios de Roma tem e boa habilidade pera neles e em outros servir", tratando-se de homem "do qual sua Santidade tem muito conhecimento e assi todos os cardeais [...] e todos tem dele satisfação." ${ }^{4}$ Satisfação que se estendia não só ao regente português, que, por carta

transcrita, a tal ponto que está em manifesta contradição com o que se diz na página 18 , que pretende ser consequência extraída deste mesmo passo.

${ }^{30}$ Mário Brandão, A Inquisição e os Professores do Colégio das Artes, Coimbra, Imprensa da Universidade, $2^{\circ}$ tomo, pp. 890-891.

${ }^{31}$ Lígia Cruz, Actas dos Conselhos da Universidade de Coimbra, Coimbra, Publicações do Arquivo da Universidade, $3^{\circ}$ volume, 1976, pp. 65-66.

32 Veja-se em José de Castro, Bragança e Miranda (Bispado), o. c., $1^{\circ}$ tomo, pp. 134-140, a enumeração dos principais cargos ligados à Igreja de cujos rendimentos gozou o Doutor António Pinto.

${ }^{33}$ Livro de Cartas..., o. c., ff. $3 \mathrm{v}^{\mathrm{o}}-4$.

${ }^{34}$ Carta de Lourenço Pires de Távora, de 12 de Abril de 1562. O. c., f. 326. 
de 25 de Setembro de 1562, em nome del-rei o louva pelo seu bom serviço e pede continue a servi-lo com o novo embaixador D. Álvaro de Castro, ${ }^{35}$ como também ao embaixador português ao Concílio de Trento, que, em missiva datada desta cidade, de 20 de Julho do mesmo ano, escreve ao seu soberano:

"Por algũas indulgências que tenho mandado pedir a Sua Santidade tenho entendido ser António Pinto mui bem ouvido e está Sua Santidade de mui bom ânimo para as cousas de Vossa Alteza e para os que estamos em seu serviço e que o dito António Pinto está habilitado e acreditado para que se Vossa Alteza mui bem possa servir dele em as cousas que naquela corte tocarem a seu serviço.»36

Como remuneração pelos valiosos serviços que prestava ao bom andamento dos negócios entre a cúria romana e a coroa portuguesa, e para além das benesses eclesiásticas que nunca cessaram de o acompanhar, ${ }^{37}$ recebeu, em 25 de Outubro de 1564 , a nomeação para desembargador da Casa da Suplicação. ${ }^{38}$

Em 22 de Abril de 1566 profere, no consistório público em que D. Fernando Meneses prestou, em nome de D. Sebastião, obediência ao recém-eleito papa Pio V, uma breve Oração latina, conforme era de praxe em tais solenidades, impressa pelo editor romano Julius Bolanus de Accoltis, que incluiu no opúsculo a brevíssima resposta que em nome do sumo pontífice pronunciou António Florebelli, bispo de Lavellino. 39

35 Corpo Diplomático Português, tomo 10, p. 31. D. Álvaro de Castro entrou em Roma a 25 de Agosto do citado ano, como se vê de carta do Doutor António Pinto, de 6 de Setembro, dirigida de Roma ao rei português e que pode ler-se na página 16 do tomo $8^{\circ}$ da colecção de textos diplomáticos acabada de citar.

36 O. c., tomo 10, página 4. Do mesmo D. Fernão Martins Mascarenhas, veja-se o que, na mesma data, escreve a Lourenço Pires de Távora: "António Pinto, do qual estou tão contente segundo tenho entendido do seu proceder que tendo Sua Alteza naquela corte por agente escusaria com sua boa diligência um embaixador mor achando ele tão boa graça em Sua Santidade." O. c., ibi., página 5. Ver também carta do mesmo ao mesmo, de 17 de Agosto do mesmo ano, o. c., ibi., página 7.

${ }^{37} \mathrm{E}$ que parece não tinha muito pejo em pedir, como se vê do seguinte passo de uma carta ao recém nomeado arcebispo de Braga D. Agostinho de Castro: "Despois que Vossa Senhoria for em Braga cuidarei nas mercês que lhe hei-de suplicar e não será sobre visitação de igrejas, por[que] nesse seu arcebispado não tenho mais que cem mil réis de pensão em ũa igreja, sendo eu natural dele." Carta datada de Roma, 30 de Maio de 1588. Arquivo Distrital de Braga, Gaveta das Cartas, doc. 112, 1 v . No mesmo arquivo, ibi., com os números 113, 115, 116 e 230 se guardam mais quatro cartas de António Pinto ao mesmo destinatário, datadas respectivamente de 13 de Junho de 1588, 5 de Setembro de 1588, $1^{\circ}$ de Outubro de 1588 e 10 de Março de 1592. As três primeiras foram escritas em Roma e a última em Madrid.

38 ANTT, Chancelaria de D. Sebastião, livro 13, f. 383 vº.

39 Veja-se o Apêndice II, onde reproduzimos o texto latino e damos a nossa versão deste discurso de circunstância, que, se não desabona os merecimentos de desempeçado latinista do Doutor Pinto, tão-pouco, pela sua brevidade e obrigada estreiteza de tema, permitiria uma brilhante revelação dos mesmos, caso eles fossem excepcionais. 
Sabemos que esteve em Portugal pelo menos nos anos de $1568^{40}$ e $1575,{ }^{41}$ sem podermos precisar a data de início e a duração das estadas. De 12 de Maio de 1580 , em plena crise sucessória do trono lusitano consequente à morte do rei D. Henrique (31 de Janeiro do mesmo ano), data a seguinte carta sua, escrita de Almeirim e dirigida a D. Filipe II de Espanha, merecedora de reprodução integral pelos elementos biográficos que fornece e por retratar à perfeição o feitio moral desta personagem:

«S[acra] C[atólica] M[ajestade]

O embaxador D. Cristóvão de Moura me deu ũa carta de Vossa Majestade per que me agardece a boa vontade com que para ele entendeu me empregava nas cousas de seu serviço, significando-me a satisfação que disso tem e segurando-me da gratificação continuando eu nela.

Beijo a real mão de Vossa Majestade pola honra e mercê que com esta carta me fez, que, como muito avantajada ao meu merecimento, estimei no grau que ela merece: e não sendo esta minha vontade, de que ora Vossa Majestade foi certificado, nova, senão muito antiga, como poderão testemunhar os embaxadores e outros seus ministros que, de vinte e cinco anos a esta parte, residiram em Roma

${ }^{40}$ Tal se conclui de carta do embaixador D. Álvaro de Castro para o rei, Roma, 17 de Junho de 1568: "Por um correio de Espanha que aqui chegou aos 14 deste entendi como António Pinto era partido de Barcelona por mar diante dele seis dias, os tempos tem corrido maus, Deus o trará a salvamento." Corpo Diplomático Português, tomo 10, página 315. A proximidade de datas também nos faz supor que, se não portador da carta de D. Sebastião para o papa Pio V, de Lisboa, 20 de Maio de 1568, pelo menos deverá ter ficado directamente inteirado, em entrevista provável com o cardeal D. Henrique, do assunto aludido no seguinte passo: "Com toda humildade envio beijar seus santos pés, muito santo em Cristo padre e muito bem-aventurado Senhor, ao Doctor António Pinto do meu desembargo escrevo que de minha parte fale a Vossa Santidade em um certo negócio de muito serviço de Nosso Senhor e que toca ao ofício da Santa Inquisição nestes reinos [...]." Biblioteca da Ajuda, 46-X-22 (Symmicta Lusitanica), ff. $61 \mathrm{v}^{\mathrm{o}}-62$.

${ }^{41}$ Fundado em informações enviadas de Lisboa pela nunciatura e hoje existentes no Arquivo Secreto do Vaticano, José de Castro, D. Sebastião e D. Henrique, Lisboa, União Gráfica, 1942, pp. 81-83, faz a súmula do que nesta altura se escreveu para Roma acerca de António Pinto: "Fora para Portugal, levando na algibeira breves óptimos do Santo Padre a recomendá-lo a el-rei e ao cardeal para ser beneficiado do melhor modo possível, recompensa aos seus serviços na Cidade Eterna. O cardeal infante nomeou-o arcediago da catedral, a segunda dignidade depois da de pontifical, com renda de 1500 ducados, [Arq. Sec. do Vat. - Nunz. Di Port. - vol. 2, f. $124 \mathrm{v}^{\circ}$ ] o que não impediu que todos, desde el-rei até à rainha Dona Catarina, se empenhassem no seu regresso a Roma a prestar os mesmos serviços que até então tinha prestado. Isto, não obstante ser cristão novo [...] o que causava maravilha à corte de Lisboa, sobretudo por ver que ele se diz não só camareiro como secretário do Santo Padre. [lugares e obras citados, f. 112] Pois apesar de cristão-novo partiu para Roma outra vez carregado de cartas de recomendação: do rei [...]; da rainha Dona Catarina [...]; da infanta Dona Maria [...]; e do cardeal D. Henrique [...]. Enfim, o Doutor António Pinto partiu de Évora para Roma no dia 3 de Dezembro de 1575." 
e noutras partes de Itália, se vivos forem, pode Vossa Majestade ter por certo que não haverá nela mudança, e que antes crecerá muito vendo-o neste Reino, como espero e desejo, porque com isso se me oferecerão ocasiões de empregar o resto que me fica da vida em seu real serviço, como tenho feito a passada no dos reis D. Anrique $\left[\mathbf{v}^{\mathbf{o}}\right]$ e D. Sebastião, vossos tio e sobrinho, que Deus tem, e de merecer honras e favores da real grandeza de Vossa Majestade, que o Senhor conserve e com muito acrecentamento prospere por largos anos.

D'Almeirim, 12 de Maio de 1580

\section{O dotor Ant $^{\circ}$ Pinto» ${ }^{42}$}

Não espanta, pois, que, com a mudança de dinastia, o Doutor António Pinto continuasse a gozar em Roma da confiança do novo rei de Portugal, que dele se serviu como encarregado dos negócios eclesiásticos pertencentes à nova coroa agregada ao seu vasto império. É com manifesto orgulho que, em carta de 23 de Maio de 1583, confessa a Filipe I:

"Senhor: Antre outras cartas que recebi de Vossa Majestade aos 20 deste mês, vinha ũa feita em 9 de Março, per que mandou significar a satisfação que recebera do que fiz de minha parte no despacho da legatia de Portugal em pessoa do sereníssimo cardeal arquiduque e a diligência com que se despacharam e enviaram as letras do arcebispado de Goa e do pálio. Beijo a real mão de Vossa Majestade por esta mercê, que é grande consolação a quem serve, como deve, entender que seu serviço e trabalho seja acepto.» ${ }^{43}$

\footnotetext{
42 Arquivo Geral de Simancas, Estado, legajo 419, carta 125, $\mathrm{r}^{\circ}$ e v ${ }^{\circ}$. Neste volumoso maço se encontram reunidos inúmeros testemunhos directos de adesão às pretensões filipinas ao trono português procedentes de compatriotas nossos das mais diversas origens sociais e profissões, a maior parte dos quais, em nossa opinião, têm o inegável interesse pedagógico de mostrar os insuspeitados abismos de baixeza moral a que pode descer a natureza humana quando movida pela auri sacra fames.
}

43 Corpo Diplomático Português, tomo 12, página 425.

No Arquivo Geral de Simancas, o códice lib 1549, Secretarias Provinciales, contém toda a correspondência que António Pinto, como agente da Coroa portuguesa em Roma, daqui enviou desde 15 de Novembro de 1583 até 28 de Novembro de 1588, data da derradeira carta, na qual escreve: "E eu me partirei amanhã, prazendo a Deus, e ficará meu sobrinho, o licenciado Francisco Vaz Pinto, como em outra digo, correndo com os negócios da Coroa de Portugal, per ordem do Conde de Olivares, até vir a pessoa que me houver de suceder, como Vossa Majestade tem ordenado." Códice citado, f. 648.

A informação relativa à data da partida é corroborada pela seguinte passagem da carta que Francisco Vaz Pinto dirigiu, a 14 de Dezembro de 1588, ao rei D. Filipe I de Portugal: "O doutor António Pinto, meu tio, se partiu desta corte no último dia do mês passado, e me ordenou da parte de Vossa Majestade que houvesse de ficar nela continuando os negócios de seu serviço, até vir a pessoa que Vossa Majestade houver por bem que lhe haja de soceder neste cargo." Ibi., f. 655.

Como "Apêndice $3^{\circ}$ " a esta Introdução decidimos transcrever uma carta e parte de outra, datadas de Março e Junho de 1585, e nas quais o Doutor António Pinto descreve a recepção com que foi acolhida em Roma a embaixada de jovens nobres japoneses, relatada também pela pena latina do jesuíta Duarte de Sande no livro De missione legatorum iaponensium ad 
No entanto, volvidos três anos, ou por julgar que a recompensa régia não correspondera às esperanças que acalentara ao prestar tão pronta adesão ao novo monarca português, ou porque de facto (ao que se pode depreender das palavras abaixo transcritas) os cofres do tesouro público se mostravam remissos em prover ao pagamento dos salários que lhe eram devidos, o facto é que respiram um tom lamentoso estes termos com que conclui uma carta ao seu amo:

"Sou forçado a dizer a Vossa Majestade que não posso continuar mais tempo este serviço, porque, de seis anos a esta parte que fui a Badajoz, tenho consumido no serviço de Vossa Majestade um honesto cabedal que tinha junto e, demais disso, empenhadas minhas rendas, pera o mesmo efeito e por outras obrigações de caridade cristã: de maneira que me não posso ajudar delas como atégora foi. Vossa Majestade me manda dar dous mil cruzados cada ano. Estes, ou polas necessidades da fazenda de Portugal, ou não sei porquê, não se me pagam senão tarde e mal. Eu sou forçado a gastar cada ano cinco mil, e tantos tenho gastado cada um dos passados, e alguns mais, vivendo com toda a moderação possível.

Pelo que beijarei a Real mão de Vossa Majestade por me mandar fazer mercê e prover no pagamento do dito ordenado de maneira que me possa sustentar, ou me conceda licença pera me tornar pera minha casa, onde servirei o milhor que puder e souber e como fazem os outros sem obrigações públicas.

E não sendo esta pera mais, Nosso Senhor guarde e acrecente o Real estado de Vossa Majestade.

De Roma, 12 de Julho de 1586

\section{O dor. António Pinto» 44}

Dada pelo rei satisfação aos seus queixumes, como parece indicar a continuação da sua permanência em Roma por mais dois anos, o Doutor António Pinto viu enfim plenamente recompensados os seus serviços ao novo governo da pátria, ao ver-se nomeado, em 1588, para o Conselho do Reino de Portugal, com assento em Madrid. Sabemo-lo por breve pontifício do $1^{\circ}$ de Outubro desse ano, no qual Sisto $\mathrm{V}$, alegando esse motivo, concede por

«tempo de dois anos ao Doutor António Pinto, seu secretário particular, arcediago e cónego da catedral de Lisboa, e a João Pinto, ${ }^{45}$ clérigo de Braga, por autoridade apostólica coadjutor com futura sucessão de António Pinto na administração do canonicato, prebenda e arquidiaconado da referida igreja, todos os frutos, rendas e

Romanam curiam dialogus, publicado pela primeira vez em Macau, no ano de 1590, e traduzido por Américo da Costa Ramalho com o título Diálogo sobre a missão dos embaixadores japoneses à cúria romana, Macau, Fundação Oriente, 1992 ( $1^{\mathrm{a}}$ ed.) e Coimbra, Imprensa da Universidade de Coimbra, volumes I e II dos "Portugaliae Monumenta Neolatina", 2009 (2 ed., com reprodução do original latino). O texto da obra de Sande correspondente à relação do Doutor Pinto encontra-se no volume $2^{\circ}$ da ed. acabada de citar, pp. 456-543.

${ }^{44}$ Códice citado, f. 255.

45 Sobrinho de António Pinto. 
demais emolumentos, tal qual como se eles residissem em Lisboa e assistissem no coro aos ofícios divinos.» ${ }^{46}$

$\mathrm{Na}$ mesma data, aliás, em carta endereçada ao arcebispo de Braga D. Agostinho de Castro, António Pinto, ao mesmo tempo que de novo se mostra um zeloso arrimo dos sobrinhos, aponta para breve a sua partida de Roma, que de facto se deu, como já atrás vimos, no final do mês de Novembro de 1588:

«[...] até que me parta, que espero será neste mês, ou, a mais tardar, no que vem: e enquanto não chega Marcos Teixeira ficará aqui neste serviço Francisco Vaz Pinto, meu sobrinho, que servirá Vossa Senhoria no que lhe mandar milhor que eu, que sou já velho e cansado.»7

À actividade governativa desenvolvida em Madrid já atrás fizemos referência, quando citámos uma passagem de carta de D. Jorge de Ataíde a D. Cristóvão de Moura. A última informação documental que temos sobre a passagem do Doutor António Pinto por este mundo é da sua própria mão e apresenta-no-lo em Madrid, no dia 10 de Março de 1592, informando o arcebispo de Braga do estado em que o achou a carta que este lhe escrevera,

"que é tal que [...] há perto de quatro meses que não pude sair da minha [casa], com gota que me tem desbaratado de maneira que posso dizer que já não presto pera nada. [...] porque eu estou tão velho e cansado que pouco poderei durar.» ${ }^{48}$

4. Chegados ao António Pinto autor da Oratio académica pronunciada em Coimbra no $1^{\circ}$ de Outubro de 1555 , cumpre-nos atentar no prólogo deste impresso, uma vez que é nele (tal como apontámos no início deste estudo) que se encontra a chave do intricado enigma de identificação que nos ocupa. Antes, porém, retenhamos o pormenor de que o autor, no corpo do seu discurso, com as seguintes palavras expressamente parece confessar que se encontra em anos juvenis: Nec mehercle dubium esse puto, quin uobis hodie et temerarius, et iunenilis cuiusdam arrogantiae appetens uidear, quod buius loci autoritatem contingere ausus fuerim ("Nem, por Deus, me restam quaisquer dúvidas de que hoje vos pareça ser atrevido e dominado por uma espécie de arrogância juvenil, por ter tido a ousadia de ocupar este lugar prestigioso"). ${ }^{49}$

Passemos agora a transcrever a totalidade do preâmbulo-dedicatória:

"Quam illustrissimo laudatissimoque Domino Ioanni, duci de Aueiro primo, Antonius Pintus cum ueneratione magna s.

\footnotetext{
${ }^{46}$ José de Castro, O Prior do Crato, Lisboa, União Gráfica, 1942, pp. 379-380. A cópia deste breve, extractado por este autor, encontra-se, consoante informa, no Arquivo Secreto do Vaticano, Arm 32, vol 27, f. 452

${ }^{47}$ Carta do $1^{\circ}$ de Outubro de 1588, de Roma, para D. Agostinho de Castro. Arquivo Distrital de Braga, Gaveta das Cartas, doc. 116, f. 1 vo.

48 Arquivo Distrital de Braga, Gaveta das Cartas, doc. 230, f. 1.

49 Oratio de scientiarum ..., o. c., f. 2.
} 
Cum postularent amici, dux quam illustrissime, ut orationem, quam de scientiarum commendatione Calendis Octobris publice habueram, uellem emittere, primum equidem recusaui, ueritus ne, emissa illa oratione, quam nec tempore satis nec otio mentis adiutus (quae duo scis ad scribendi studium maxime requiri), sed partim dolore, partim negotio impeditus composueram, temere in uaria hominum iudicia diuersasque uoluntates inciderem. Nam, cum Idibus Augusti infaustam sane et acerbam de obitu fratris patruelis mei Ferdinandi de Campo, in quo et amorem et spem collocabam, epistolam accepissem, confestim ad eius sororem Leonoram, quae me arcessierat, profectus sum, ut ad eius negotium apud serenissimum regem conficiendum, cuius pro incredibili pietate et beneficentia tua patrocinium ac protectionem suscepisti, omnia tuo iussu praepararem.

Sed, cum postulantibus amicis rem ut sibi uidebatur honestam resistere non possum, tuo fretus praesidio, princeps maxime, hoc publicae editionis periculum subiui. Itaque paruum munusculum tibi multis de caussis offerre sum ausus: tum quia te studiorum omnium egregium et laudatorem et patronum academia nostra nacta est, ita ut quicquid sit de scientiarum laude tuo nomine consecratum non dubitem quin et placide accipias et iucunde ac alacri animo perlegas, tum quod hunc ingenioli mei fructum, quantuluscumque est, tuo tibi iure refferre debui, nam quotiens in regiam tuam me conferebam ad sororia negotia opem expetens, totiens clarissimum os tuum et iucundissimum, in quo tantum ingenii et eruditionis lumen apparet, me maxime ad scribendum illustrabat; accedit etiam te illis uirtutibus, quas in optimo principe inesse oportet, humanitate et beneficentia, praestantissimum esse.

Accipiens igitur hanc oratiunculam, quia parua tuo nomini consecrata sit, Artaxerxis

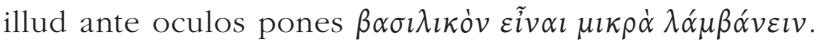

Leonorae sororis opitulaberis, cuius equidem, nisi eam praesidio haberes, grauius miseriam et orbitatem, quam fratris desiderium, deplorarem; opitulandi munus recordabere te, cum princeps natus sis, a Deo Optimo Maximo accepisse.

Vale, dux felicissime, Deumque precor ut maximam nominis tui amplitudinem, cum illustrissima natorum tuorum prole, diutissime felicissimeque conseruet.

Conimbricae, Idibus Octobris."

Ou seja, em português:

"Com grande respeito António Pinto envia saudações ao ilustríssimo e mui afamado Senhor D. João, primeiro duque de Aveiro

Ilustríssimo duque, tendo-me os amigos pedido que quisesse dar a lume a oração que, em louvor das ciências, eu pronunciara em público no $1^{\circ}$ de Outubro, a minha primeira reacção foi recusar, temendo que, uma vez publicada aquela oração, para cuja composição não só não dispusera de tempo suficiente nem tivera o concurso 
da tranquilidade de espírito (requisitos ambos que, consoante sabeis, sobremaneira se requerem para a actividade literária), mas também me vira embaraçado em parte pelo desgosto e em parte por ocupações, afrontaria de modo temerário os juízos variados e as diversas disposições de espírito dos homens. É que, como tivesse recebido a 13 de Agosto uma assaz triste e dolorosa carta noticiando a morte do meu primo co-irmão Fernando do Campo, em quem depositava afecto e esperança, de imediato parti a encontrar-me com a sua irmã Leonor, que me chamara, a fim de, para tratar diante do sereníssimo rei dos interesses dela, cujo patrocínio e defesa, em conformidade com a vossa excepcional humanidade e bondade, tomastes a vosso cargo, tudo aprontar segundo as vossas ordens.

Mas, uma vez que não posso resistir a amigos que me pedem uma coisa que parecia honrosa, apoiando-me na vossa ajuda, nobilíssimo senhor, arrostei este risco de sair à luz pública. E assim atrevi-me, por muitas razões, a oferecer-vos um pequenino presente: não apenas porque a nossa Academia encontrou em vós um egrégio apologista e patrono de todos os estudos, de tal maneira que não duvido de que acolheis de bom grado e ledes com alegria e entusiasmo tudo quanto se vos dedique acerca do louvor das ciências, mas também porque com toda a justiça vos deveria devolver como vosso este fruto do meu parco engenho, por poucochinho que ele valha, porquanto, todas as vezes que me dirigia ao vosso paço, esperando ajuda para os assuntos da minha prima, sempre a vossa nobilíssima e ameníssima boca, que dá mostras de tamanho brilho de inteligência e erudição, ${ }^{50}$ sobremodo me inspirava para escrever; acresce também que vós vos singularizais por aquelas virtudes que melhor quadram ao príncipe perfeito: a afabilidade e a bondade.

Por conseguinte, ao aceitardes este pequeno discurso, porquanto, embora de somenos, vos está dedicado, lembrai-vos daquele dito de Artaxerxes: É próprio do rei receber coisas pequenas. ${ }^{51}$

Acudireis à minha prima Leonor, de quem, se a não tomardes sob a vossa protecção, estou certo de que mais deplorarei a miséria e desamparo do que me punge a saudade do irmão; lembrai-vos que, ao nascerdes príncipe, recebestes de Deus Óptimo Máximo a obrigação de socorrer.

\footnotetext{
50 Parece não haver exagero áulico nestes encarecimentos dos dotes intelectuais do duque D. João de Lencastre (1501-1571), a darmos crédito às palavras com que D. Jerónimo Osório se lhe refere no f. $103 \mathrm{v}^{\circ}$ do tratado dialogado De regis institutione et disciplina, Lisboa, João de Espanha, 1571, que aqui apresentamos na nossa versão: "Acabando eu de dizer isto, interveio então D. Francisco de Portugal: - Como eu gostaria que o duque de Aveiro, D. João, tivesse podido estar presente nesta nossa conversa! Tenho a certeza de que ter-lhe-ia sido de muito prazer! - Quanto a mim, disse eu, não sinto grande desgosto por ele não estar presente, pois se aqui estivesse ter-nos-ia podido amedrontar com a sua inteligência, que é poderosíssima." Vd. D. Jerónimo Osório, Da Ensinança e Educação do Rei, Tradução, introdução e anotações de A. Guimarães Pinto, Lisboa, INCM, 2005, pp. 158-159.
}

51 Cf. Plutarco, Artaxerxes, 5. 
Ficai de saúde, felicíssimo duque, e rogo a Deus que, com imensa prosperidade e incessantemente, conserve o máximo prestígio da vossa nomeada, em companhia da vossa ilustríssima prole.

Em Coimbra, 15 de Outubro.» ${ }^{52}$

Da leitura deste prólogo se conclui que a dedicatória ao duque de Aveiro tem como objecto primordial buscar o valimento do ilustre titular para a desamparada Leonor, privada do arrimo do irmão Fernando do Campo, precoce e inesperadamente falecido no correr de 1555 e primo co-irmão de António Pinto. Uma vez estabelecida a identidade dos primos Campo e, se possível, a relação de Leonor com a Casa de Aveiro, estaria dado o passo decisivo para a determinação de quem era (ou melhor, de quem não era) este António Pinto.

Ora, durante alguns anos malograram-se todas as nossas investigações nesse sentido, quando, no local e momento menos esperados, o mero acaso das nossas leituras vagabundas nos desatou de golpe todos os nós deste problema. De facto, numa fazenda do interior do Pará, onde veraneávamos, vimo-nos na necessidade de satisfazer o nosso vício de leitura com a sumaríssima biblioteca de que os nossos hospedeiros dispunham, que se reduzia a uma Bíblia e a uma edição, de catadura muito modesta mas eruditamente anotada por Capistrano de Abreu e Rodolfo Garcia, dos Diálogos das Grandezas do Brasil, de Ambrósio Fernandes Brandão. ${ }^{53}$ Ora, em nota a um passo do texto quinhentista em que se faz referência ao primeiro donatário da capitania de Porto Seguro, Pedro do Campo Tourinho, informava Rodolfo Garcia que este intrépido povoador:

- era vizinho de Viana do Minho;

- era casado com Inês Fernandes Pinta;

- a 19 de Novembro de 1554, com a mulher, renunciara a capitania (que tomou em doação em 7 de Outubro de 1534) a favor de seu filho Fernando do Campo, mandado logo meter na sua posse, e a quem, por falecer sem herdeiros, substituiu sua irmã Leonor do Campo, que obteve confirmação em 30 de Maio de 1556;

- e, finalmente, que Leonor do Campo, em 16 de Julho de 1559, viúva, obteve alvará de licença para vender a capitania de Porto Seguro ao duque de Aveiro, sendo a escritura passada a 9 de Agosto deste ano e confirmada a 6 de Fevereiro de 1560.54

52 O. c., f. $1 \mathrm{v}^{\mathrm{o}}$.

53 Ambrósio Fernandes Brandão, Diálogos das Grandezas do Brasil, Rio de Janeiro, Dois Mundos Editora, 1943.

${ }^{54}$ Resumimos o conteúdo da Nota 29 à obra citada na nota anterior, pp. 90-92. Tivemos também presente o que escreveram sobre estas personagens: Francisco Adolfo de Varnhagen, História Geral do Brasil, 5ª edição, São Paulo, Edições Melhoramentos, São Paulo, 1948, tomo 
Acresce que Pedro Tourinho, pelo seu carácter assomadiço e anticlerical, acabou, em 1546, por ser posto em ferros por ordem do vigário de Porto Seguro, que improvisou um tribunal e procedeu a inquirições, formando um processo que, juntamente com o acusado, vieram para Lisboa em 1547. Entre os inquiridos no processo, que foi recentemente publicado, ${ }^{55}$ encontramos um António Pinto, cunhado de Pedro Tourinho, um Pedro Mousinho, escudeiro do duque de Aveiro e um Manuel Colaço, capelão do mesmo titular, os dois primeiros com dois anos de residência no Brasil e o último aqui residente há ano e meio. A documentação compulsada pelo editor do processo inquisitorial permitiu-lhe escrever que: "Em 1544 Leonor do Campo, residente em Viana na Rua de São Sebastião, aparece no rol da cobrança do empréstimo ordenado nesse ano [pelas Cortes de Almeirim], escusando-se do pagamento por seu pai ser capitão no Brasil." 56

Eis, pois, finalmente e sem sombra de dúvidas, o primeiro passo na identificação do António Pinto autor da Oratio de 1555, passo que, ao que supomos, nos permite pôr desde já de parte os três outros homónimos com que, em maior ou menor grau, tem sido confundido. É certo que com alguma plausibilidade se poderia pensar numa identificação com o António Pinto poeta latino e mestre-escola maltrapilho. Pendemos a crer, no entanto, que o pobre homem que, numa data indeterminada entre 1560 e 1569, se caracteriza como "velho", muito dificilmente seria o mancebo que em 1555 pede ao auditório académico escusa pelo seu arrojo juvenil.

Cumpre-nos agora fazer alguns comentos ao exposto.

A primeira observação tem a ver com o facto de, sendo António Pinto primo co-irmão de Fernando e Leonor do Campo, e sendo a mãe destes Inês Fernandes Pinto (ou Pinta, ao modo quinhentista), parecerá ao leitor da tradução portuguesa que o parentesco entre os primos vem por via materna. Dá-se, porém, o caso que a língua latina é muito mais rigorosa que a nossa na especificação dos graus de parentesco, e o que de facto lemos na dedicatória da Oratio é frater patruelis, isto é, "primo co-irmão pelo lado do pai", circunstância que ainda se torna mais

$1^{\circ}$, p. 210; Capistrano de Abreu, Caminhos Antigos e Povoamento do Brasil, Belo Horizonte-São Paulo, Editora Itatiaia, 1988, p. 33-34

55 António Matos Reis, Entre o Sucesso e a Desgraça: Pêro do Campo Tourinho, fundador de Porto Seguro, Viana do Castelo, Centro Cultural do Alto Minho, 2000. A transcrição do processo ocupa as pp. 91-171.

A menção de Leonor do Campo pode ler-se no fólio 52 do códice manuscrito com cota 533, intitulado "Contribuição do concelho de Viana em relação ao pedido feito pelo rei nas Cortes de Almeirim de 1544", existente no Arquivo Municipal de Viana do Castelo, cuja reprodução nos foi gentilmente cedida pelo seu director, o Dr. António Maranhão Peixoto, a quem queremos deixar publicamente consignado o nosso agradecimento por toda a cooperação com que contribuiu para o enriquecimento deste trabalho e para a divulgação do nome e obra deste até hoje ignorado Autor vianense.

${ }^{56}$ O. c., p. 10. Do processo consta também como testemunha um "Pêro Correia cavaleiro fidalgo: que tinha com ele [Tourinho] contrato feito para casar com sua filha." O. c., p. 114. É de supor que este matrimónio contratado nunca se tenha concretizado. 
complicada ao atentarmos que Pedro Tourinho tinha um cunhado, solteiro, também chamado António Pinto. Tendo em conta o modo aparentemente arbitrário como os sobrenomes mais díspares se distribuíam no século XVI pelos filhos dos mesmos pais, pode perfeitamente dar-se o caso de António Pinto ser de facto sobrinho de Pedro Tourinho, e não da mulher: com a qual, aliás, muito verosimilmente, Tourinho poderia ter laços de consanguinidade. Saliente-se, no entanto, que o linhagista Felgueiras Gayo, no título consagrado aos Tourinhos de Viana, ao enumerar os filhos de Gil Pires de Tourinho e de Branca Quesado, pais de Pedro do Campo Tourinho, entre os irmãos deste não aponta nenhum de sobrenome Pinto: o que tão-pouco é conclusivo, porquanto poderia tratar-se de apelido da família do cônjuge, repescado pelo filho António nos costados do outro progenitor. ${ }^{57}$

A segunda observação tange à ligação que aqui se notou com a casa do duque de Aveiro. É possível que o interesse de D. João de Lencastre pela capitania de Porto Seguro já fosse anterior à morte de Fernando do Campo (leva-nos a supô-lo a presteza com que, conforme se depreende das palavras de Pinto, o duque nos aparece disposto a servir de medianeiro perante o rei na defesa dos assuntos da desamparada Leonor do Campo) e parece-nos provável que tenha sido despertado, ou pelo menos avivado, por aquelas pessoas ligadas à sua Casa que encontrámos como depoentes no processo de Pedro Tourinho.

Avancemos agora um passo na determinação mais concreta da identidade do nosso António Pinto.

O erudito e arguto historiador da Universidade de Coimbra, Mário Brandão, supôs que o António Pinto autor da Oratio do $1^{\circ}$ de Outubro de 1555 é a personagem do mesmo nome que, como substituto, ocupou, em 4 de Março de 1555, a docência da cadeira de maior prestígio (a $1^{\mathrm{a}}$ classe) das humanidades no Colégio das Artes quando Diogo de Teive, lente da mesma, ascendeu ao principalado desta Escola Real. Como prova aponta uma carta do jesuíta Padre Leão Henriques, reitor do Colégio de Jesus, dirigida a um confrade e datada de 4 de Março de 1555, na qual o informa de que a substituição tinha sido encarregada a Pinto. Desdobra depois o sagaz investigador o currículo de dois Antónios Pintos, parecendo-nos que se pode depreender das suas palavras que na atribuição da autoria do texto latino e da docência da $1^{\text {a }}$ classe de Humanidades oscila entre o Pinto do Mogadouro e um Pinto de Coimbra. Põe de parte:

«um outro António Pinto, natural de Viana de Caminha, que não deve ser o professor do Colégio Real, visto que só em 4 de Fevereiro de 1555 prestou prova de ter ouvido do Curso de Artes que lera no Colégio dos Jerónimos Mestre Luís Álvares Cabral, e do que regera Mestre Nicolau de Grouchy no Colégio das Artes, o tempo

57 Felgueiras Gayo, o. c., volume 9, p. 613. Comete alguns ligeiros deslizes, talvez mais consequência de leituras imperfeitas do que erros substanciais. 
e livros requeridos para bacharel em Artes" [Autos e Graus, t. 5, 1. 3, f. 40], ${ }^{58}$ "grau que lhe foi conferido em 21 do dito mês" [códice e livro citados, f. 42)].59

Ora, menos feliz do que nós, a quem uma acidental descoberta pôs no bom caminho, a intuição do eminente mestre falhou ao descartar da autoria da Oratio o António Pinto vianense, seu indisputável autor, se neste incerto mundo pode haver certezas sobre alguma coisa. Aliás, não se nos antolha momentosa a objecção que invoca, porquanto o facto de o António Pinto minhoto receber o grau de bacharel em Artes a 21 de Fevereiro não parece razão impeditiva para nos princípios de Março se encontrar a leccionar como substituto de Teive.

Para concluir, chamemos a atenção para dois factos que decorrem da análise da documentação académica que sem margem para dúvidas se refere ao nosso António Pinto vianense.

O primeiro tem a ver com a insólita circunstância de António Pinto colar grau de bacharel em Artes volvidos quase cinco anos após a conclusão da parte curricular necessária para a admissão ao respectivo exame. Com efeito, sabemos que o candidato àquele grau em artes "tinha de demonstrar previamente por meio de duas testemunhas ajuramentadas, escolhidas entre os condiscípulos, que frequentara dois e meio o Curso de Artes, durante os quais ouvira explanar a lógica e ética e dois livros de filosofia natural de Aristóteles." ${ }^{60}$ Como acabámos de ver, António

58 No Arquivo da Universidade de Coimbra copiámos directamente os termos do assento a que a citação supra faz referência:

"António Pinto

Provou António Pinto, de Viana de Caminha, diante do Senhor Reitor, que ouvira, do Curso que leu o mestre Luís Álvares no Colégio dos Hierónimos, e do Curso que leu o mestre Nicolau Grochi, todo o tempo e os livros necessários pera se fazer bacharel em Artes. E foram testemunhas Pero de Sousa e Hierónimo de Forcada, e eu, Diogo de Azevedo, o escrevi a 4 de Fevereiro de 1555 anos."

59 Mário Brandão, A Inquisição e os Professores do Colégio das Artes, o. c., tomo $2^{\circ}$, pp. 890-891. É a seguinte a acta da cerimónia aludida no texto, também por nós copiada no Arquivo da Universidade de Coimbra:

"Graus dos bacharéis artistas do Curso de Manuel de Pina

Aos vinte e dias do mês de Fevereiro de 1555 anos na cidade de Coimbra e sala dos paços del-rei nosso Senhor onde se fazem os semelhantes autos, sendo í presente o senhor frei Diogo de Murça, reitor, e o doutor Afonso do Prado, decano das faculdades de Teologia e Artes, e assi toda a mais faculdade das Artes: o mestre Manuel de Pina deu o grau de bacharel na dita faculdade aos estudantes abaixo nomeados, que são do Curso que ele ora lê e que começou o mestre Monçon, e assi deu o grau de bacharel a outros estudantes que foram doutros Cursos, de que abaixo faço menção. E o dito grau deu às quatro horas da tarde e os ditos bacharéis são os seguintes: [seguem-se, nesta página 42 e na seguinte, vinte e sete nomes, entre os quais:] [...] António Pinto, de Viana de Caminha, do Curso do mestre Luís Álvares Cabral [...]. E foram testemunhas dos ditos graus de bacharéis que o dito Manuel de Pina lhe deu os mestres António de Souto e Melchior Beliago e Francisco Carlos, que os examinaram, e o doutor Afonso do Prado e o doutor António Vaz e o mestre Fabrício e outros muitos e eu, Diogo de Azevedo, lhe dei juramento que esto escrevi."

${ }^{60}$ Mário Brandão, Coimbra e D. António, o. c., p. 93. 
Pinto provou a sua frequência dos Cursos de Artes regidos pelos mestres Nicolau de Grouchy e Luís Álvares Cabral. Ora, tal como mostrou o indefesso historiador que nos tem servido de guia, o único Curso ministrado em Coimbra pelo professor francês foi sincrónico com o do colega português acabado de citar e decorreu entre 1547 e 1550, ${ }^{61}$ sendo ponto assente que o mestre bordalês em Fevereiro de 1551 já se encontrava bem longe das terras lusas, certamente escarmentado com as prisões que viu sofrerem os seus colegas e amigos Diogo de Teive, João da Costa e Jorge Buchanan. ${ }^{62}$ Qual a razão que levaria o nosso Autor a protelar durante tempo a conclusão formal da única graduação académica que lhe conhecemos?

O outro facto a merecer-nos referência, conquanto não possuamos elementos documentais que nos permitam fazer quaisquer extrapolações, é a conclusão a que chegámos de que este António Pinto minhoto foi em Coimbra, no Colégio dos Jerónimos e no Curso de mestre Luís Álvares Cabral, condiscípulo de D. António, futuro Prior do Crato, tal como em Guimarães também o fora o seu homónimo transmontano. Assim, sabemos que D. António, em 9 de Março de 1550, provou ter ouvido "do mestre Luís Álvares Cabral todo o tempo e os livros necessários pera se fazer bacharel em Artes." ${ }^{3}$ Ora, sendo o tempo de frequência do Curso de Artes exigido por lei, tal como já dissemos, dois anos e meio, segue-se que o António Pinto, de Viana do Minho, e D. António, filho natural do infante D. Luís, frequentaram em conjunto parte (como veremos) do Curso que aquele professor iniciou em Outubro de 1547 no Colégio dos Jerónimos. Com efeito, D. António abandonou no ano seguinte o Colégio de S. Jerónimo, trocando-o pelo Mosteiro de Santa Cruz, sendo acompanhado nesta mudança pelo seu mestre Luís Álvares, que continuou a ler o Curso de Artes no novo cenário dos gerais dos Crúzios. A maior parte dos condiscípulos acompanharam o régio pupilo e concluíram, em Março de 1550, sob a regência do mesmo mestre, o Curso começado dois anos e meio antes. ${ }^{64}$ Porém, os alunos pertencentes à Ordem de S. Jerónimo e dois outros escolares leigos - o nosso António Pinto e um Henrique Mendes - transferiram-se para o Colégio das Artes, passando a frequentar o Curso de Artes que então aí professava o mestre francês Nicolau de Grouchy. ${ }^{65}$

\footnotetext{
${ }^{61}$ Id., Coimbra e D. António, o. c., p. 30.

${ }^{62}$ Id., A Inquisição e os Professores do Colégio das Artes, o. c., tomo 1ª, p. 668-669.

63 Arquivo da Universidade de Coimbra, Autos e Graus, t. 5, 1. 2, f. 40.

${ }^{64}$ Mário Brandão, Coimbra e D. António, o. c., p. 49.

65 Arquivo da Universidade de Coimbra, Autos e Provas de Cursos, t. 3, 1. 3, f. 108.
} 
APÊNDICES 


\section{APÊNDICE $1^{\circ}$ \\ Biblioteca Nacional de Lisboa - Códice 8920}

$\mathbf{A}$

[85] Versos de António Pinto, estando preso na cadea, sobre ũas palavras que disse a um desembargador.

Ad clarissimum et illustrissimum Dominum Laurentium Siluium maximum iustitiae rectorem in Regnis Lusitaniae et ad amplissimum senatum sacri praetorii conquestio.

Quid meruit, rector iustissime, caelitus orbi Lisiaco concesse: meae quae causa catenae tam durae ac uitae non conuenientis inermi. Quid merui, patres conscripti: crimine uestrum

5 quo laesi nomen: quae furta aut uulnera feci quas caedes quae damna dedi: quae incendia ieci quae [stupra] aut thalami quae tetigi sacra pudici religiosarum quae rupi claustra: sacratae quod maiestatis crimen: quo grande tonantis

10 offendi numen: caelo numen: caelo quae bella paraui more giganteo: poenis ut talibus angar inclusus densis tenebris et carcere caeco personae et carae tanto discrimine uitae ut si latro ferus uel si plagiarius essem

15 uel quem pompeia uel sanctio iulia damnat leniter ex merito quidquid patiare ferendum [quae] uenit indigne magnum fert poena dolorem clamat et hic clamor supero peruadit Olympo

[85 $\mathbf{v}^{\mathbf{o}}$ est mea poena quidem uarie cumulata meaque

20 sorte aliena satis laesus non laedor iniquo conuicio tactus patior quis (quaeso) quis umquam supplicium laesi laedentis uidit honorem uel poenam culpae uel culpam demere poenae me miserum quanti cogor meminisse doloris 


\section{APÊNDICE $1^{\circ}$}

\section{$\mathbf{A}$}

[Tradução:]

[85] Queixume dirigido ao nobilíssimo e ilustríssimo Senhor Lourenço da Silva, regedor-mor de justiça nos Reinos de Portugal, e aos excelentíssimos membros da Casa da Suplicação

Justíssimo regedor, concedido pelo Céu à terra lusitana, porque mereci? Qual a causa da minha cadeia tão dura e não apropriada a uma vida inofensiva?

Membros do tribunal: porque mereci? Com que crime atentei contra o vosso prestígio? Que furtos ou violências físicas cometi, que assassínios, que danos ocasionei, que incêndios ateei, que estupros, ou que santidade toquei de honesto tálamo? Que clausuras de religiosas violei, que delito contra a sagrada majestade que me levasse a cair no desagrado da potestade grande do Tonante, que guerras, à imitação dos Titãs, aparelhei contra o Céu, para ser atormentado por tais penas, encerrado em densas trevas e num cárcere sombrio, com tamanho risco para o meu prestígio e a estimada vida, como se fosse um feroz salteador ou um ladrão de escravos ou alguém a quem as leis júlia ou pompeia condenam?

Calmamente te prestarias a tudo quanto se deve suportar por o merecer, mas causa grande dor o castigo que vem injustamente. Brada, e este brado penetra pelo elevado Olimpo. A minha pena foi acrescentada de vários modos, e não sou assaz ultrajado por [uma pena] que não pertence à minha condição; suporto, ferido por iníquo baldão.

Pergunto: quem, quem jamais viu que o suplício do ultrajado suprimisse a honra do que ultraja ou a pena da culpa ou a culpa da pena?

[85 $\mathbf{~ v}^{\mathbf{0}}$ ] Ai mofino de mim, que sou forçado a lembrar-me de tão grande dor! Não deve dar-se tribulação ao atribulado. Olha-se como culpa replicar a quem diz "Não falas verdade". Que poderia a razão, que poderia a regra do estrito direito se é tida por mais elevada a condição daquele ofício do que a minha? Deste modo tanto mais 
25 Afflicto non danda afflicio: culpa uidetur dicenti "uerum non dicis" reddere uerbum quod ratio possit stricti quod regula iuris officii illius ratio si maior habetur quam mea: sic tanto grauior sua culpa profecto

30 "omne animi uitium tanto conspectius in se crimen habet: quanto maior qui peccat habetur" ut Iuuenalis aut satirae descriptor acerbae quanto maior eris tanto submissior inquit Tullius eloquii princeps auctorque latini

35 iura pios reddunt homines: quid mitius aequo iustitia est melior cui sit clementia iuncta quam cui durities: "ius summum: iniuria summa" caelestes animos diuina scientia iuris efficit: ex caelo prodit sapientia caelo mitia cuncta quidem crudelia nulla leguntur si mea fata uolunt ne tales soluere poenas soluere me facient: sed non meruisse ualebunt haec mala mihi dant infelicia: sed tu "parce pias scelerate manus", aequissime rector,

45 parce: memento tui generis quod condidit ille Siluius Aeneas genus a quo principe ducis huic pater Aeneas troius quo iustior alter nec pietate fuit nec bello maior et armis ut fert Virgilius romanae gloria musae.

50 Vos quoque, conscripti patres, moderamine iusto mancipis obsequio uestro subscribite causae sitque satis uinctum semel has uidisse tenebras me quia nulla uiro poena hac est maior honesto. ${ }^{66}$

${ }^{66}$ Mantivemos a pontuação e grafia do manuscrito original, corrigindo, de forma assinalada no texto, um ou outro deslize evidente do copista.

Nota à tradução: Levado pela necessidade de acomodar ao seu caso particular o acervo de citações clássicas ou jurídicas que pretendeu embrechar nestas súplicas metrificadas, António Pinto cai em vários passos num estilo demasiado alusivo que só o conhecimento do processo judicial ou dos atropelos de que se queixa poderia iluminar. Daí o carácter de tentame que atribuímos à nossa versão, não nos parecendo, por outro lado, que se nos levará a mal não termos perdido demasiado oleum et operam com este colega quinhentista. 
grave [é] a sua culpa, pois é certo que "quanto em mais alta conta alguém é tido, tanto mais visivelmente nele todo o defeito de ânimo incorre na pecha de crime", como diz Juvenal ${ }^{67}$ ou o pintor da acerba sátira, "quanto mais elevado estiveres, tanto mais humilde", consoante Túlio, príncipe e modelo da linguagem latina, "o direito torna os homens benévolos: que [há] de mais suave do que a justiça? Melhor justiça é aquela a que se juntou a indulgência do que a que se uniu à dureza", "direito extremo, extrema injustiça", 68 a divina ciência do direito torna celestiais os espíritos, a sabedoria nasce do Céu, o Céu recolhe tudo quanto é suave e nada do que é cruel.

Se o meu Fado quer que eu sofra este castigo, far-me-á sofrê-lo: mas não conseguirá tornar-me dele merecedor. Um Fado ruim me causa estas desventuras. Mas tu, justíssimo regedor, "abstém-te, abstém-te de tornar criminosas as tuas mãos piedosas." ${ }^{69}$ Lembra-te da tua linhagem, que fundou aquele Eneias Sílvio, príncipe de que procedes: foi seu pai o troiano Eneias e não existiu ninguém mais justo nem superior nem mais denodado nas armas e na guerra do que ele, conforme narra Virgílio, glória da musa romana.

Vós também, veneráveis magistrados, com justo tino, mediante a vossa deferência, aprovai a causa do reclamante e seja pena bastante ter visto no cárcere uma vez estas trevas, porque para um varão honrado não há pena maior do que esta.

67 Sat 8. 140-141.

${ }^{68}$ De officiis, 1. 10. 33.

${ }^{69}$ Eneida, 3. 42. 


\section{B}

[96] Outros versos de António Pinto sobela mesma prisão

Ad illustrissimum Dominum Laurentium Siluium maximum in Regnis Lusitaniae rectorem iustitiae et amplissimum sacri praetorii senatum petitio

Rector iustitiae caelestis maior imago iudiciis in terris expressa figura superni quid miserum lacerare sinis uinctumque senemque infirmum et guttae magnis angoribus actum

5 iustitiae patris summi clementia iuncta haeret et ira pio sua demulcetur amore respice: quod princeps respexit maximus: ille haec mala quae patior: censet grauiora ferendis quod iubet id fieri manda diuna quid obstat

10 iussa sequi: causis cum sint mandata probatis est pietate tua iam nunc mea poena leuanda precipue cum fata luo: non crimina: sed tu parce diu tenebris indignis "parce sepulto" tam premit unius qui sentit honore diei

15 poena uirum quantum multos tolerata per annos. Vos quoque collegii iustissima numina sacri doctores famulo iustum conferte fauorem huic uestro: illiusque irae subscribere tantae parcite nobilitas nescit saeuire, sed ultro est

20 pacis amans: saeuitque animis ignobile uulgus [96 $\mathbf{v}^{\mathbf{0}}$ Est quod debetis iustumque piumque modestum non eadem uulgus debent et lumina rerum impedimenta probant : quam me crudeliter angat quam nocet inualidae nulla ratione saluti

25 nam quid (te summi testor moderatorem Olympi) ad rem : cum nostri sit gratia regis [homagi] quod mihi iure meo uos concessistis: id ergo cum teneam quid habere domi prohibebor abunde rege uolente: bona frustra fit gratia regi

30 Adde quod alterne loquitur lex regia nostrae materiae: namque illa domi uel in arce prehendi praecipit: eligere ergo potest qui debitor exstat praterea cur acta mihi si nulla nocebunt Haec bona iura uolunt rapidis comburere flammis

35 causa quidem nulla et acta nulla ac omnia nulla occidunt hominem nulli (quo iure) nocentem de ratione satis: uirtuti cetera trado uestrae: quae semper fuit ardentissima iusti. 


\section{$\mathbf{B}$}

[Tradução:]

Petição ao ilustríssimo Senhor Lourenço da Silva, regedor-mor de justiça nos Reinos de Portugal, e aos excelentíssimos membros da Casa da Suplicação

Regedor, mor imagem da celestial justiça, nítido retrato na Terra do juiz do Alto, porque deixas atormentar um desgraçado aprisionado e velho, enfermo e arrastado à lágrima por muitas aflições? A clemência do Pai supremo está estreitamente ligada à justiça e a Sua ira apazigua-se com o compassivo amor. Atende àquilo a que atendeu o mais alto dos príncipes. Ele julga que estes males que suporto são mais pesados que toleráveis, ordena tu que se faça aquilo que [Ele] manda; que impede de seguir os mandados divinos? Uma vez que se trata de mandados [em] causas aprovadas, desde agora a minha pena merece ser aliviada pela tua compaixão, sobretudo porque sou castigado pela minha má sina, não por delitos, mas tu "poupa quem durante muito tempo jazeu sepultado em trevas indignas", ${ }^{70}$ a pena de um só dia rebaixa tanto na honra o varão que sente quanto a que é suportada durante muitos anos.

Também vós, justíssimos numes do Santo Tribunal, mais doutos, concedei um justo favor a este vosso fâmulo: abstende-vos de dar o vosso assentimento à tão grande ira daquele, a nobreza não sabe ensanhar-se, mas é naturalmente amante da paz: e o vil vulgo ensanha-se contra as almas. [96 $\mathbf{v}^{\mathbf{0}}$ ] Vós estais obrigados ao que é justo, benévolo e comedido: o vulgo e as luminárias do mundo não estão obrigados a um mesmo proceder. As dificuldades demonstram quão cruelmente me atormentam, quanto sem qualquer razão me faz mal à débil saúde. De facto (tomo-te por testemunha, ó Senhor do alto Olimpo), que importa: uma vez que [existe a graça da menagem do nosso rei], que vós me concedestes por meu direito; logo como tenho isso, porque serei proibido de possui-lo abundantemente em casa, querendo-o o rei? [Debalde se está nas boas graças do rei?] Acresce que a lei régia fala alternadamente à nossa matéria, pois determina que seja preso em casa ou na fortaleza: logo, o condenado pode escolher. Além disso, por que é que, se nenhumas acções me hão-de fazer mal, querem queimar estes bons direitos com rápidas chamas? Certamente que uma causa e acções nulas e um total de coisa nenhuma matam um homem que a ninguém fez mal? Com que direito?

Basta no que tange a razões. O demais entrego-o à vossa virtude, que sempre se abrasou no vivo amor da justiça.

${ }^{70}$ Cf. Eneida, 3. 40. 


\section{APÊNDICE $2^{\circ}$}

R. ANTONII PINTO LVSITANI ORATIO ad Pium V Pont. Max. In publico consistorio habita. Illustriss. D. Ferdinando Menesio Sebastiani I Portugaliae Regis nomine oboedientiam praestante. XXII Aprilis, MDLXVI. Romae. Apud Iulium Bolanum de Accoltis. In Banchis, in uia Paulina.

[Aii] Si ullo unquam tempore, Pater Beatissime, Christiana Respublica nefaria haereticorum impietate lacerata, spem concipere aliquam potuit: fore, ut tandem aliquando in pristinam illam suam integritatem, dignitatem, ac potentiam restitueretur: eam quidem uel maximam Sanctitate tua in hanc celsissimam Pontificiae dignitatis Sedem euecta, propositam sibi esse arbitratur. Nam diuina plane, totiusque humanae affectionis expers, Tui in apostolici istius muneris principatum assumptio: hoc ipsum indicare, et anteactae uitae tuae Sanctitas, morum integritas, praestans bonitas, et sapientia: tuum illud ardentissimum in Christiana religione, et Catholica fide tuenda, et propaganda studium, omnibus manifeste uidentur ostendere: inueniri non potuisse similem tibi, qui conseruaret legem excelsi. Plurima quidem P. B. uirtutum exempla, tua mihi uita suppeditat: quorum iucunda commemoratio, et ad imitationem, et ad ipsius Reip. spem corroborandam magnopere pertineret: quae cum nota, perspectaque sint omnibus: oratione prosequi superuacaneum esse existimaui. Omnes quidem Christianos Principes, praeclarae eximiaeque tuae uirtutis admiratione adductos certum est, accepto amplissimi istius tibi delati honoris nuntio, maxima quadam laetitia fuisse perfusos. Serenissimus uero Portugalliae Rex Sebastianus, ut te semper praecipua quadam ante alios beneuolentia fuerat prosecutus: ita ex amplificatione dignitatis tuae singulare quoddam praeter [Aii $\mathbf{v}^{\mathbf{o}}$ ] ceteros gaudium cepit. Itaque indictis statim, per omnes Regni sui partes, publicis supplicationibus, gratias Deo agendas curauit, quod Spiritus Sancti gratia, corda uestra Patres amplissimi illustrauerit: ut sapientissimis sententiis, Pontificem Max. eum dixeritis, in quo ea insunt religionis, sapientiae, iustitiae, aliarumque uirtutum omnium ornamenta: ut Pontificia potestas 


\title{
APÊNDICE $2^{\circ}$
}

\author{
[TRADUÇÃO: ]
}

Oração proferida pelo R. António Pinto, português, ao Santo Padre Pio V, no consistório público em que o ilustríssimo Senhor D. Fernando de Meneses prestou obediência em nome do rei de Portugal D. Sebastião I, em 22 de Abril de 1566.

Em Roma, na oficina de Julius Bolanus de Accoltis. Em Banchis, na uia Palatina

[Aii] Se jamais, Santíssimo Padre, a cristandade, dilacerada pela abominável impiedade dos hereges, pôde acalentar alguma esperança de que algum dia há-de vir a ser restituída àquela sua originária integridade, dignidade e poder, certamente julga que a tem certa diante dos olhos com a elevação de Vossa Santidade a esta excelsa cadeira da dignidade pontifícia. É que é indício disto mesmo a vossa assunção, totalmente divina e sem qualquer intervenção de afectos humanos, ao principado dessa função apostólica, e a santidade, integridade de costumes, excepcional bondade e sabedoria da vossa vida precedente, aquele vosso ardentíssimo desvelo em zelar e propagar a religião cristã e a fé católica, parecem mostrar com toda a evidência que não se teria podido encontrar nenhum outro como vós para conservar a lei do Céu. Certamente, Santíssimo Padre, que a vossa vida me fornece inúmeros exemplos de virtudes, cuja aprazível evocação serviria não apenas para a imitação, mas também em grande medida para fortalecer a esperança da mesma cristandade; mas achei que seria supérfluo referi-los, uma vez que são públicos e notórios a toda a gente. É indubitável que todos os príncipes cristãos, atraídos pela admiração pela vossa notável e excepcional virtude, foram inundados por uma alegria deveras grande ao recberem a notícia dessa importantíssima honraria a vós concedida. Mas o sereníssimo rei de Portugal, D. Sebastião, assim como vos honrara com uma especial benevolência antes dos outros, da mesma maneira se regozijou singularmente mais do que os restantes com os acrescentamentos da vossa dignidade. [Aiii $\mathbf{v}^{\mathbf{0}}$ ] E assim, depois de imediatamente ordenar preces públicas por todas as partes do reino, tratou de que se dessem graças a Deus por a graça do Espírito Santo ter inspirado os vossos corações, eminentíssimos Padres, para, com conselhos muitíssimo sábios, dizerdes a este Sumo Pontífice em que se fundam os ornamentos da religião, da sabedoria, da justiça e de todas as outras virtudes, por 
omni ex parte adornata, et decorata esse uideatur. Vt uestrum autem prudentissimum iudicium, unanimemque concordiam, miris in caelum laudibus extollit: ita ingentes uobis gratias agit, quod Christianae Reipub. ita consuluistis: ut optimi cuiusque expectationi, integritate et uirtute uestra satisfeceritis. Gratulatur etiam uobis Patres, quod praeclarissimo isto facto, quo solius Dei honorem, eiusque ecclesiae utilitatem, uos secutos ostendistis, immortalem apud omnes homines laudem gloriamque comparastis. Gratulatur Catholicae Ecclesiae, quod talem fuerit sortita rectorem. Tibi uero P. B. delatum honorem maximum, et summam quam adeptus es de Christiano populo benemerendi auctoritatem, et potestatem, quanto potest animi studio gratulatur, sibi gaudet, et cum regnis suis in Domino exultat. Misisset Serenissimus Rex huius suae laetitiae significandae, debitaeque oboedientiae tibi praestandae causa, oratorem ad te alterum: sed cum propter magna locorum interualla, itinerisque difficultates, nimis seram gratulationem futuram uideret: et suam animi uoluptatem primo quoque tempore cuperet declarare, Ferdinando Menesio generis nobilitate, uirtuteque praestanti uiro, Regni Consiliario, suoque apud hanc Sedem apostolicam Oratori, quem propter eius fidem, atque prudentiam ipse plurimi facit, et pro ea qua te prosequitur [Aiii] obseruantia, tibi aliorum omnium gratissimum fore existimauit, negotium per litteras dedit, ut hoc munere apud tuam Beatitudinem quamprimum diligentissime fungeretur. Is igitur non minus hilari, et iucundo, quam pio animo, potentissimi Sebastiani Primi Portugalliae, et Algarbiorum Regis Serenissimi nomine, quae ab optimo, et obsequentissimo filio expectari, et desiderari possunt, obsequium, reuerentia, oboedientiam, tibi PIE Pontifex Optime: sanctaeque huic apostolicae sedi, summa pietate pollicetur, et praestat. Regnaque sua omnia, opes, et fortunas, gentes sibi subditas, et earum studia, tuae auctoritati sic defert, ut se, et quascunque obtinet prouincias, in tua potestate fore, tibi persuasum esse magnopere uelit. Profitetur etiam nihil unquam sibi optatius futurum, quam maiorum suorum uestigiis inhaerendo, istius Sanctae sedis potestatem, dignitatem, et auctoritatem tueri, conseruare, et augere. Vetus enim hoc Portugalliae Regum institutum est: Vetus atque perpetua in Romanos Pontifices et Apostolicam Sedem, Christianamque Religionem, fides, studium, pietas, et obseruantia. Nam si ipsius Regni initia repetam, eius quidem pars maxima, Regum uirtute, et opera, ab impia Sarracenorum tyrannide liberata Apostolicae huius Sedis cultui, oboedientiaeque restituta est: illisque in Africam usque compulsis, atque fugatis, urbes plurimas, et oppida munitissima illius prouinciae, infidelibus expulsis Reges ipsi praestanti uirtute, ditioni suae, Christianaeque Reipub. adiecerunt. Quid hoc loco commemorem mirabilem, maioribus inauditam, paeneque incredibilem totius Oceani maris nauigationem? qua non tam Imperii augendi, quam Christianae religionis propagandae studio, innumerabiles [Aiii $\mathbf{v}^{\mathbf{o}}$ ] hominum copias, ornatissimis 
forma a que o poder pontifício se veja adornado e honrado por todas as partes. Por outro lado, assim como com admiráveis encómios exalça o vosso prudentíssimo juízo e unânime concórdia, do mesmo modo vos dá imensas graças porque de tal forma velastes pela cristandade que, com a vossa integridade e virtude, satisfizestes as expectativas de todos os melhores. Também vos felicita, Padres, por esse acto, com que mostrastes ter atendido à honra de Deus e à utilidade da Sua Igreja e obtivestes diante dos homens louvor e glória imortais. Felicita a Igreja católica por ter sido quinhoada com um tal dirigente. Mas a vós, Santíssimo Padre, com todas as veras do coração vos felicita, rejubila e juntamente com os seus reinos se alegra no Senhor pela máxima honraria que vos foi concedida e pela autoridade e poder que obtivestes de bem merecer do povo cristão.

O sereníssimo rei ter-vos-ia enviado um outro orador para transmitir este seu contentamento e vos prestar a devida obediência, mas, atendendo à grande distância e às dificuldades da jornada, se dava conta de que haveria de ser um parabém demasiado tardio, e como desejava manifestar também o prazer da sua alma na primeira oportunidade, a D. Francisco de Meneses, varão eminente pela nobreza de linhagem e pela virtude, conselheiro real e seu enviado nesta Sé Apostólica, de quem ele faz muita conta devido à sua lealdade e prudência e que, por causa desta deferência com que vos acompanha, [Aiii] considerou que seria mais do vosso agrado que todos os outros, encarregou-o por carta de desempenhar quanto antes e com toda a diligência diante de Vossa Santidade esta incumbência. Portanto, este, com ânimo não menos contente e jubiloso do que reverente, em nome do sereníssimo D. Sebastião, rei de Portugal e dos Algarves, a vós, Pio Óptimo Pontífice, e a esta Santa Sé apostólica, com a mais completa reverência promete e presta tudo quanto se pode esperar e desejar de um óptimo e muito respeitador filho: acatamento, reverência e obediência, e de tal maneira põe sob a vossa autoridade todos os seus reinos, riquezas, fortunas e os povos a si sujeitos e seus serviços que faz muita questão em persuadir-vos de que ele e todos os territórios que possui hão-de estar sob o vosso poder. Também confessa que nunca nada lhe há-de ser mais desejável do que, seguindo as pisadas dos seus antepassados, velar, conservar e acrescentar o poder, dignidade e autoridade dessa Santa Sé. É que este é o imemorial modo de proceder dos reis de Portugal: uma imemorial e incessante lealdade, amor, respeito e acatamento pelos pontífices romanos, pela Sé Apostólica e pela religião cristã. Na verdade, se recordar os começos do próprio reino, a maior parte dele, libertada da ímpia tirania dos sarracenos graças à coragem e iniciativa dos reis, foi restituída ao acatamento e obediência desta Sé Apostólica, e, depois de expulsos e repelidos aqueles para a África, os mesmos reis, com superior coragem, após delas expulsarem os infiéis, colocaram sob a sua soberania e fizeram entrar na cristandade inúmeras cidades e praças de armas muito bem fortificadas. Para quê lembrar aqui a admirável, inaudita para os antepassados e quase inacreditável navegação de todo o mar oceano? Com esta navegação, levados do zelo não tanto de aumentar o império quanto de propagar a religião cristã, transportaram inúmeras [Aiii $\mathbf{v}^{\circ}$ ] 
classibus, terra marique periculis grauissimis superatis, in Orientem usque in Arabiae, Persidis, Indiae, atque Sinarum regiones traiecerunt? Quid captas ibi a nostris urbes, et sublatis idolis, Christiano ritu aedificata templa? Quid tot religiosorum hominum collegia illuc transmissa, annuis Regum sumptibus liberalissime toleratas? Quid denique referam, tot tantasque Indiae regiones atque oras, Lusitanorum uictoriis peragratas, et nostrae Religionis trophaeis illustratas, Christianisque legibus initiatas, imbutas, excultas? Cognita quidem satis atque perspecta sunt haec omnia, cognita innumerabilia alia clarissimorum Portugalliae Regum in Christiana religione propaganda, illustria facta, et immortalitate digna. Aethiopiae Imperatorem, quod Christum uerum Deum agnoscit, non multis ab hinc annis ne Turcarum potentia imperio pelleretur, Regum Portugalliae praesidio, et auxilio, defensum fuisse: et catholicam Romanae Ecclesiae doctrinam summa opera apud illius Imperium gentes praedicari, doceri, et seminari, Episcopis atque presbiteris religiosissimis uiris, non mediocri impensa eo missis, Reges nostros procurasse, quis est qui nesciat? Haec maiorum suorum praestantis fortitudinis, et erga Sedem apostolicam, Christianamque religionem pietatis, et obseruantiae exempla; Sebastianus Rex, optime atque religiosissimae Reginae auiae et Cardinalis principis amplissimi, patrui sui magni, sanctissimis monitis praeceptisque imbutus, maximarum etiam rerum, ac diuinae gloriae cupiditate incensus, et inflammatus, maioribus in dies studiis retinet, obseruat, et amplificat. Mazaganum oppidum in Africa, sub ipsius Regis potestate, altero ab hinc anno a Xirifi potentissimo $[\mathbf{A i v}]^{71}$ exercitu, peditum sexaginta, et equitum triginta ferre millibus obsessum, aggeribusque paene obrutum: duorum non amplius Lusitanorum millium Regii praesidii uirtute defensum, et uiginti fere millibus hostium caesis atque interfectis longa iam obsidione maximoque periculo liberatum fuisse: nota res est. Clara etiam ipsius religio, ac pietas extitit, et omnibus grata: quod nuper in Tridentina Synodo, una cum Regni Episcopis, Oratorem suum adesse uoluit, uirosque doctissimos qui Rom. Pontificis, et Apostolicae huius Sedis dignitatem, et auctoritatem pro uiribus tuerentur. Quorum fidei, et diligentiae in eo munere obeundo, testes locupletissimi esse ii possunt Patres, qui tunc Apostolicae sedis legati Concilio praefuerunt. Quam uero sit studiosus, tum retinendae, obseruandaeque Orthodoxae religionis, et Catholicae ueritatis, tum impiae temeritatis, et haereticae audaciae uindicandae, et coercendae, Lusitania ipsa, ceteraque ipsius Regna optime declarant; quae salutaribus institutis, ita sunt munita, et saepta, ut impia haereticorum dogmata, eo, ad hanc usque diem non irrepserint; sed sincera, ac pura Romanae Ecclesiae doctrina, et obseruantia, summo illic consensu ab

\footnotetext{
71 Não numerada no original.
} 
tropas de homens, em esquadras bem equipadas, depois de superados imensos perigos na terra e no mar, até ao oriente para as regiões da Arábia, da Pérsia, da Índia e da China. Para quê referir as cidades que os nossos aí conquistaram e os templos que edificaram segundo o rito cristão, depois de destruídos os ídolos? Para quê falar de tão grande número de religiosos para lá enviados, muito liberalmente sustentados com subsídios anuais dos reis? Por derradeiro, para que hei-de aludir a tão grande quantidade e a tantas regiões e países visitados pelas vitórias dos portugueses, celebrizados com os triunfos da nossa religião e instruídos, ensinados e civilizados pelas leis cristãs? Tudo isto é assaz conhecido e notório, conhecidos os outros inumeráveis cometimentos, dignos da imortalidade, dos claríssimos reis de Portugal no propagar da religião cristã. Quem é que desconhece que o imperador da Etiópia, poucos anos atrás, a fim de não ser destronado pelo poderio dos turcos, foi defendido pela ajuda e socorro dos reis de Portugal e que os nossos soberanos com a máxima diligência se empenharam em que entre os povos daquele império se pregasse, ensinasse e espalhasse a doutrina católica da Igreja romana, mediante bispos e sacerdotes de grande religiosidade, para ali enviados com não pequena despesa? O rei D. Sebastião, instruído pelos santíssimos conselhos e lições da excelente e mui religiosa rainha sua avó e do eminentíssimo cardeal-infante, seu tio-avô, além de abrasado e inflamado pelo desejo dos maiores cometimentos e da glória divina, com empenho cada dia maior mantém-se fiel, respeita e acrescenta estes exemplos de extraordinária valentia e de reverência e acatamento para com a Sé Apostólica e a religião cristã dados pelos seus antepassados. É coisa sabida que a fortaleza de Mazagão, pertencente à coroa deste mesmo rei, foi cercada há dois anos ${ }^{72}$ por um poderosíssimo exército do xerife, [Aiv] de sessenta mil infantes e à roda de trinta mil cavaleiros, e quase assoberbada por bastiões, e, defendida pelo denodo do socorro régio de não mais de dois mil portugueses, depois de desbaratados e mortos cerca de vinte mil inimigos, libertada de um já longo assédio e de um perigo extremo.

A religiosidade e piedade do mesmo também é manifesta e grata aos olhos de todos, porque ainda há pouco quis que no Concílio de Trento, juntamente com os bispos do reino, ${ }^{73}$ estivesse presente um embaixador seu ${ }^{74}$ e varões muitíssimo doutos para que estes, na medida das suas possibilidades, defendessem a dignidade

72 O Doutor António Pinto cincou na aritmética, pois o célebre cerco de Mazagão aqui referido verificou-se entre Fevereiro e Maio de 1562, portanto quatro anos antes. Veja-se: Augusto Ferreira do Amaral, História de Mazagão, Lisboa, Publicações Alfa, 1989, pp. 114-128; Agostinho Gavy de Mendonça, História do famoso cerco que o Xarife pôs à fortaleza de Mazagão defendido pelo valeroso capitão-mor dela Rui de Sousa de Carvalho reinando neste reino a sereníssima rainha Dona Caterina primeira do nome em Portugal no ano de 1562, Lisboa, Vicente Álvares, 1607; J. M. Queirós Veloso, D. Sebastião. 1554-1578. Lisboa, Empresa Nacional de Publicidade, 1935, pp. 40, 70 e 73.

73 D. Bartolomeu dos Mártires, D. João Soares e D. Gaspar do Casal.

${ }^{74} \mathrm{O}$ já atrás referido D. Fernão Martins Mascarenhas. 
omnibus retineatur. Ea denique iam nunc est Rex ipse uirtutis indole, ea signa dat in illa aetatis teneritate, animi ad pietatem, ad iustitiam, ad fortitudinem, ad omnemque uirtutem natura ipsa compositi: ut certo sperandum sit; cum se corroborauerit, non ea tantum quae a maioribus accepit, prudentissime gubernaturum: uerum etiam uetere iam Regum nostrorum consuetudine, et instituto, Christo Duce, susceptis in Barbaras, et religioni nostrae inimicas gentes expeditionibus, et Christiani nominis, et imperii sui fines longe lateque propagaturum. [Aiv $\mathbf{v}^{\mathbf{o}}$ ] Is itaque sicut id sibi studio habuit, ut quamuis omnium Regum longissime ab hac Vrbe disiunctus, primus tamen omnium tibi gratularetur, seque semper tibi, atque huic Apostolicae Sedi oboedientem fore profiteretur: ita posthac in Sanctitate tua colenda, obseruanda, modis omnibus demerenda, eum se praestabit, ut primas quoque partes fidei, pietatis, et obseruantiae, a nemine sibi praeripi patiatur; omninoque ita se geret, ut dignissimus ab omnibus, et a te imprimis, Pater Beatissime, iudicari debeat, quem haec Sancta Sedes sibi unice amandum, fouendum, ornandum, planeque paterna complectendum caritate arbitretur ac statuat. Rogat autem Deum Optimum Maximum ut Sanctitatem tuam quam diutissime ad nominis sui gloriam, et sanctae uniuersalis Ecclesiae utilitatem, incolumem tueatur et seruet. 
e a autoridade do pontífice romano e desta Sé Apostólica. ${ }^{75}$ Da fé e desvelo deles no cumprimento desta incumbência podem ser testemunhas mui fidedignas estes Padres legados da Sé Apostólica, que então presidiram ao Concílio. Mas o grande zelo que ele tem, tanto em conservar e respeitar a ortodoxia religiosa e a verdade católica, como em reprimir e castigar o ímpio desatino e o atrevimento herético, demonstram-no à evidência o próprio Portugal e seus restantes senhorios, os quais de tal maneira se encontram protegidos e defendidos por disposições salutares que as ímpias opiniões dos hereges até hoje não se introduziram neles, mas a genuína e pura doutrina e observância da Igreja romana ali se mantém com o mais completo assentimento de todos. Finalmente, o próprio rei é dotado de uma tal propensão para a virtude, dá, numa idade tão moça, tais indícios de um espírito naturalmente inclinado à piedade, à justiça, ao denodo e a toda a espécie de virtudes que certamente é de esperar que, quando chegar à maturidade, não se limitará a governar com a máxima prudência sobre aqueles territórios que recebeu dos seus maiores, mas também, seguindo já a antiga tradição e costume dos nossos reis, há-de empreender, sob os pendões de Cristo, expedições guerreiras contra os povos bárbaros e inimigos da nossa religião, e dilatar ao longe e ao largo as fronteiras tanto do cristianismo quanto do seu império. [Aiv $\mathbf{v}^{\mathbf{0}}$ ] E assim este rei, da mesma maneira que teve o empenho de, embora de todos os reis seja o que se encontra mais apartado desta cidade de Roma, mesmo assim ser o primeiro em felicitar-vos e jurar que há-de ser sempre obediente a vós e à Sé Apostólica, assim de futuro, no reverenciar, acatar e por todas as vias bem merecer de Vossa Santidade, distinguir-se-á por também não permitir que ninguém o preceda e leve a primazia nos deveres da lealdade, respeito e acatamento, e em tudo agirá de tal sorte que todos, a começar por vós, Santíssimo Padre, o devam julgar como o mais merecedor de que esta Santa Sé o considere e julgue digno de ser singularmente amado, favorecido, honrado e estreitamente abraçado com amor fraternal. Além disso, pede a Deus todo-poderoso que, para glória do Seu nome e utilidade da santa Igreja católica, por longuíssimo tempo mantenha e conserve de perfeita saúde Vossa Santidade. ${ }^{76}$

${ }^{75}$ Entre outros, o também já citado D. Jorge de Ataíde, Frei Francisco Foreiro e Diogo de Paiva de Andrade. Da relevância deste último como um dos teólogos mais acatados no Concílio de Trento e expositor apologético do novo corpo doutrinal aí definido dá mostras o livro Orthodoxarum explicationum libri decem, Veneza, ex officina Iordani Zileti, 1564.

76 Do original desta Oração de Obediência existe uma edição fac-similada, com nota bibliográfica do Prof. Martim de Albuquerque e tradução portuguesa de Miguel Pinto de Meneses, publicada pelas Edições Inapa, Lisboa, 1988. O Autor da nota introdutória nada adianta ao que Barbosa Machado escrevera sobre António Pinto. 
(Página deixada propositadamente em branco) 


\section{APÊNDICE $3^{\circ}$}

\section{Arquivo Geral de Simancas - lib 1549, Secretarias Provinciales}

\section{[79] Senhor}

Os Japões que vieram nas naus da Índia do ano passado e passaram pela corte de Vossa Majestade chegaram a esta aos 22 do presente mês de Março, e per ordem do $\mathrm{Papa}^{77}$ entraram quasi privadamente; e digo "quasi" porque todavia vieram com eles ũa companhia de cavalos ligeiros, que por ordem de Sua Santidade os foi encontrar daqui ũa jornada pera os segurar de ladrões, e eu os fui também encontrar a um pedaço fora da cidade, e os trouxe a casa dos padres da Companhia de Jesu, onde lhes tinham aprestado seu gasalhado.

Ao dia seguinte pela manhã cedo per ordem também do Papa, assentado com os ditos padres da Companhia, se tornaram a sair da cidade a ũa Vinha que se diz de Papa Júlio, perto das portas, vestidos a uso de sua terra, e ali os foi buscar a mesma companhia de cavalos que os trouxera, e a guarda de pé do Papa, e as famílias dos Cardeais com suas mulas e do Conde de Olivares, e a família do mesmo Papa os esperava à porta da cidade, e os três deles cada um em seu cavalo bem ornado que mandou Jacobo [79 $\mathbf{v}^{\mathbf{0}}$ ] Bom Compagno, cavaleiro de Alcântara, per ordem também de Sua Santidade.

Acompanhados desta maneira e com número infinito de gente popular, vieram pelo meo da cidade e foram até o palácio de S. Pedro, onde o Papa, acompanhado dos Cardeais em consistório público, os estava esperando: e, ali chegados, lhe beijaram o pé como embaxadores dos Reis de Bungo e d' Arima, e de D. Bartolomeu, cujas cartas, traduzidas em linguagem italiana, se leram em alta voz; e fez por eles a oração um padre da Companhia, português, que se chama Gaspar Gonçalves, mui docta, prudente e elegante, e como tal foi de todos aprovada e louvada, ${ }^{78}$ de que enviarei o treslado, e assi das cartas e da reposta que se lhes deu pelo secretário.

\footnotetext{
77 Gregório XIII, que viria a falecer a 10 de Abril de 1585, ou seja, poucos dias depois de esta carta ter sido escrita.

${ }^{78}$ Desta notável peça oratória se fizeram várias edições, publicando-se a $1^{\text {a }}$ sob o seguinte título: Oratio nomine Legatorum Japoniae habita in publico Consistorio Romano 23 Martii, Roma, apud Franciscum Zanettum, 1585.
} 
Acabado o acto, ao recolher do Papa, levaram o D. Mâncio e D. Miguel a faldea a Sua Santidade, como costumam fazer os embaxadores dos Reis que vem dar obediência, e em tudo e per tudo se usaram com eles as mesmas ceremónias, nem faltou a artelharia do castelo de Santo Ângelo, nem a do palácio.

O Papa e alguns Cardeais com outras muitas pessoas se comoveram tão notavelmente que houve muitas lágrimas de alegria de se verem naquele teatro embaxadores de três Reis novamente convertidos à fé católica $[\mathbf{8 0}]$ e de partes tão remotas desta cabeça da Igreja e cidade, na qual, despois de fundada, nem em tempo da República nem dos grandes Emperadores, não se lê haver jamais entrado recado nem embaxada desta gente, e foi mui benzida e louvada dos virtuosos a memória dos Reis de Portugal, predecessores de Vossa Majestade, por haverem sido autores de tão heróica, religiosa e santa obra, e a singular virtude e piedade de Vossa Majestade, que a vai reforçando.

Foram convidados aquela manhã a comer do Cardeal de S. Sisto com alguns padres da Companhia, e, feita oração à tarde na igreja de S. Pedro, se tornaram à casa dos padres da Companhia, onde (como disse) estão agasalhados.

O D. Julião adoeceu dous dias antes de chegar a Roma e, posto que desejou achar-se com os outros neste acto e se aparelhou pera isso e foi até à vinha, ali o carregou tanto a febre com um fluxo de sangue dos narizes que não se estreveu ir a cavalo: levei-o eu em coche diante, cuidando que ao menos poderia estar no consistório. Nem a isso se atreveu nem pareceu ao médico se devia fazer, por ser o acto longo, e assi o levei a beijar o pé a Sua Santidade antes que decesse ao consistório, que o recebeu com muito amor $\left[\mathbf{8 0} \mathbf{v}^{\mathbf{o}}\right]$ e gasalhado, esforçando-o que não temesse a doença, que não seria nada, e esperava em Deus que com saúde tornaria à sua Pátria. E, feito isto, o mandei levar a casa no mesmo coche, e ainda hoje está mal, mas diz o médico que não será de perigo.

Hoje, que é festa da Anunciação de Nossa Senhora, costuma o Papa vir a cavalo pontificalmente de S. Pedro até a igreja da Minerva, mosteiro da Ordem de S. Domingos, e ouvir ali missa, e distribuir certa esmola pera casamento de pobres donzelas. Quis Sua Santidade que estes Japões o acompanhassem, e assi vieram com ele a cavalo no lugar dos embaxadores, e estiveram à missa no lugar outrossi de embaxadores.

Dizem que o Grão-Duque de Toscana lhes fez muito gasalhado em Pisa, onde se achava quando eles por ali passaram, e despois em Florença e em Sena ho mandou fazer. O Conde de Olivares os tem visitado ontem e oferecido-lhes tudo o que lhes cumprir de sua casa e pessoa. Eu os vejo cada dia duas vezes e assi determino fazê-lo enquanto aqui estiverem, entendendo que se haverá Vossa Majestade por servido disso, e porque vejo que os mesmos moços e o Geral da Companhia folgam e se alegram disso. E avisarei do mais que suceder deles.

Nosso Senhor guarde e acrecente a vida e real estado de Vossa Majestade De Roma, 25 de Março de 1585

O dor. António Pinto 
[127] [...] Os Japões são também partidos mui contentes, honrados e amerceados de Sua Santidade, ${ }^{79}$ que não encurtou nada a demostração de amor e d'obras que Papa Gregório com eles usava. Disseram-me os padres da Companhia de Jesu que lhes assignara seis mil ducados de renda cada ano na Collettoria di Spagna para ajuda da sustentação dos colégios do Japão, e aqui lhes dera em dinheiro despois da morte de Papa Gregório, para o caminho e outras cousas, perto de três mil ducados.

Armou-os Sua Santidade cavaleiros a todos quatro, com toda a ceremónia do pontifical, véspera da Ascensão, na capela, acabadas as vésperas, em presença dos Cardeais que nelas se acharam.

Vão por Veneza, Ferrara e Milão e tornar-se-ão a embarcar em Génoa. Levam breve do Papa per que os encomenda muito a Vossa Majestade.

Prazerá a Deus que aproveitem estas obras apostólicas para alumiar o entendimento daquelas gentes do Japão.

\section{A Oratio académica de António Pinto}

1. Época de profunda crença na força actuante da palavra falada, o Renascimento procurou usá-la com restaurado vigor e arte em todas as dimensões da vida humana, não apenas naquelas em que a cultura greco-latina dela se servira com especial beleza e eficácia ao serviço de propósitos filosóficos (de que os diálogos platónicos ou ciceronianos são o paradigma) e político-sociais (domínio em que Demóstenes e o mesmo Cícero se nos apresentam como o emblema máximo em cada um dos idiomas clássicos), mas igualmente naqueles sectores ou momentos da existência em sociedade que o mundo antigo não conhecera ou privilegiara, e que sobretudo se prendem com a nova orientação religiosa imposta ao Ocidente pelo cristianismo.

Cingindo-nos a Portugal e ao subgénero literário que para simplificar designaremos como "orações renascentistas" - ou seja, as que se servem do latim como veículo de expressão e revelam na sua redacção uma intenção literária sensível às injunções da cultura greco-latina, em novo processo de recuperação às luzes do movimento humanista -, podemos, seguindo a proposta do Prof. Costa Ramalho, ${ }^{80}$ repartir pelas seguintes variedades o acervo que hoje nos resta neste ramo da literatura novilatina: 1) orações de obediência (de que é exemplo a que atrás reproduzimos e traduzimos, da autoria do Doutor António Pinto transmontano, pronunciada diante de Pio V, em Roma, em 22 de Abril de 1566, no consistório em que o embaixador

79 Sisto V, eleito Papa a 24 de Abril de 1585.

${ }^{80}$ Do Autor citado leia-se, na Enciclopédia Verbo, t. 14, coll. 677-678, o artigo "Orações Latinas". 
português D. Fernando de Meneses prestou obediência em nome de D. Sebastião); 2) orações de entrada (pronunciadas quando alguma alta personagem fazia a sua entrada pública numa povoação, que deste modo lhe tributava a sua homenagem colectiva) ${ }^{81}$; 3) orações panegíricas (que podem exalçar tanto uma alta personagem, como, mediante o elogio dos seus membros, uma instituição) ${ }^{82}$; 4) orações de sapiência ou académicas, modalidade na qual se inclui a obra que agora se publica, e que se destinavam a ser lidas na abertura do ano lectivo: que em Portugal, inicialmente, se verificava a 18 de Outubro - dia de S. Lucas -, passando em seguida para o dia de $S$. Remígio $-1^{\circ}$ de Outubro. Às orações pronunciadas na universidade, primeiro em Lisboa e, depois de 1537, em Coimbra, cumpre que se juntem as proferidas no Colégio das Artes, inaugurado em Fevereiro de 1548.

2. Não podemos esperar das orações de sapiência grandes voos de originalidade ou sustidos troços de superior beleza literária, pois em geral mais não constituíam do que discursos de circunstância exigidos pelo cerimonial académico, nos quais o orador, mais ou menos sensível ao magistério do Pro Archia de Cícero, modelo obrigado desta espécie de discursos, se sentia compelido ao elogio sucessivo das ciências professadas nas diferentes escolas que formavam a Academia. Isto significa que, além da teologia (à qual cabia o lugar de honra), das ciências jurídicas (que se repartiam em direito civil e canónico) e da medicina, o esquema oratório a seguir deveria contemplar todo o conjunto de saberes que lato sensu se designavam por Artes e integravam os tradicionais quadrívio (que agrupava as artes reales, ou componente científica: aritmética, geometria, música, e astronomia) e trívio (que incluía as artes liberales, ou componente humanística: gramática, retórica e dialéctica), ou seja, o septívio da Escola medieval e de raiz aristotélica. Pedia também a normativa retórica que o discurso encetasse com uma captatio beneuolentiae, mediante a qual o orador encomiava os ilustres presentes e se desculpava das apoucadas forças com que contava para empresa de tamanho tomo, e finalizasse com uma peroração na qual, de par com o exalçamento do soberano reinante, se exortava a mocidade estudantil a empenhar todo o esforço e desvelo na suada conquista do saber.

Ora, a Oração de António Pinto satisfaz à perfeição a todos os requisitos acabados de enumerar e de forma alguma destoa entre as congéneres assinadas por nomes muitíssimo mais sonantes do que o modesto quase anonimato de que a arrancámos. De facto, não obstante a grave pecha (pelo menos para o nosso senso moral) de

${ }^{81}$ Vd., como exemplo, "A saudação de Vila Real", de Salvador Fernandes, estabelecimento de texto e tradução de Américo da Costa Ramalho, Latim Renascentista em Portugal, Coimbra, INIC, 1985, pp. 99-117.

82 Vd., como exemplos: Oração de André de Resende pronunciada no Colégio das Artes em 1551, reprodução fac-similada, leitura moderna, trad. e notas de Gabriel de Paiva Domingues, Coimbra, Biblioteca Geral da Universidade, 1982, e A oração sobre a fama da Universidade (1548), de Juan Fernández, prefácio, introdução, tradução e notas de Jorge Alves Osório, Coimbra, Instituto de Estudos Clássicos, 1967. 
plagiato que a mareia, a Oratio revela um equilíbrio de construção, um à-vontade no manuseio das fontes (ainda que, muitas delas, de segunda mão) e uma tal ou qual elegância literária que nos fazem entrever um discípulo bem aproveitado e um jovem mestre dotado de mente metódica e sensibilidade estética.

Assim, após uma leitura de todas as orações congéneres que entre nós a precederam, a de Pinto parece-nos não desmerecer entre as melhores, em primeiro lugar, pela forma bem articulada como, no início, nos traça um relativamente longo elogio da Sabedoria, que o Autor apresenta como o coroamento da obra divina da Criação. Depois, pela imparcialidade com que aborda de modo sistemático e igualmente desenvolvido todas as áreas do saber expendido nas escolas que integravam a Academia Conimbricense, com a particularidade, que provavelmente decorria de ser esse o terreno que lhe era mais familiar, de conceder um tratamento especial à Gramática, domínio no qual inclui a poesia e a história. Finalmente, abona certa sensibilidade estética o esquema metafórico a que subordinou a apresentação de todo o discurso e que o leva a comparar a sabedoria a uma árvore, de que os galhos são os diferentes "ramos" do saber que sucessivamente vai mostrando e encarecendo. Por outra parte, no que tange aos quilates do seu latim, se não são de molde a guindar o Autor à plana de um estilista primoroso como André de Resende ou D. Jerónimo Osório, têm contudo o lustre de um instrumento linguístico desenvolto, eficaz e ajustado ao escopo em vista, o que já não seria de somenos se tivermos em conta os anos moços em que António Pinto então provavelmente se encontrava.

Terá presumivelmente sido esta inexperiência, que conjecturamos, o motivo que levou António Pinto a acostar-se com demasiada complacência à oração que cinco escassos anos antes Pedro Fernandes pronunciara no mesmo lugar e pouco depois os prelos entregaram à publicidade e à memória. É que o cotejo de ambas as peças oratórias, além da repetição daquela farragem pseudo-erudita da praxe neste tipo de peças e que se transmite de uns autores para os outros sem que possamos estabelecer uma paternidade definida, leva-nos a concluir que Pinto efectuou um decalque voluntário do trabalho do seu antecessor na tribuna académica. Este plágio - para nos servirmos do vocábulo apropriado, ainda que de desagradável ressonância para a audição moderna - incidiu em dois planos, o estrutural e o de conteúdos, sendo muito mais extensa a sua acção no primeiro. Com efeito, a mera leitura superficial dos dois discursos isenta-nos da necessidade de mostrar a forma como, embora António Pinto apresente a sucessão dos diferentes ramos do saber de acordo com uma ordem diversa da de Pedro Fernandes, todavia, uma vez lançado no desenvolvimento de um tema específico, leva-o a efeito cingindo-se as mais das vezes a uma lógica discursiva que é amiúde a do antigo estudante da Sorbona. ${ }^{83}$ Quanto às coincidências textuais, menos frequentes, é certo, elas, mesmo assim,

${ }^{83}$ A fiarmo-nos na informação de Barbosa Machado, que, no artigo que lhe consagra na Biblioteca Lusitana, escreve: "Foi estudar a Paris, onde recebeu o grau de Mestre em Artes, frequentou pelo espaço de seis anos a jurisprudência canónica [...].” 
apresentam-se em algum número e podem enquadrar-se em duas variedades: a da cópia quase literal e a da glosa ou amplificação. De ambas damos em seguida alguns exemplos significativos, cabendo a Pedro Fernandes a autoria dos textos transcritos em primeiro lugar:

\section{A)}

[Fernandes, 25; cf. supra p. 158] Verum eloquens ipse, quamuis per se satis excellens sit, tamen, Deus bone, quanto erit excellentior ac diuinior si incredibili dicendi facultati uicinam illam ac finitimam dialecticorum scientiam adiungat! Sine qua qui in reliquarum doctrinarum inquisitione et studio uersantur non minus mibi temerarie [26] facere uidentur quam qui, in Cretensium labyrintho errantes, se se inde sine aliquo Daedalo putant euasuros. ("Mas embora o homem eloquente seja por si mesmo alguém de muito extraordinário, todavia, santo Deus, quão mais extraordinário e fora do comum não será se ao singular talento oratório ajuntar aquela ciência da dialéctica que com ele convizinha e está unida! Sem ela os que se entregam à investigação e estudo das demais ciências aos meus olhos procedem com desatino igual ao daqueles que, errando perdidos pelo labirinto de Creta, cuidam que daí hão-de escapar sem a ajuda de algum Dédalo.").

[Pinto, 10v ; cf. infra, p. 404] Verum eloquentia, quamuis per se ornatissima et praestantissima facultas sit, quae possit de quacumque re proposita, ut apud Platonem iactat Leontinus Gorgias, apte et copiose dicere, tamen eam multo ornatiorem, praestantiorem et potentiorem putabo si, quemadmodum cum dialectica ramo coniuncta est, sic studio pariter et lucubratione coniungatur. Sine qua non modo nullam, qui reliquarum doctrinarum stadia percurrunt, metam contingere possunt, sed etiam in medio cursu claudicant atque deficiunt. ("Mas embora a eloquência seja por si mesma um talento muito notável e distintíssimo, que habilita a falar apropriada e copiosamente acerca de qualquer assunto proposto, como (consoante se lê em Platão) se jactava Górgias de Leontinos, todavia considerá-la-ei muito mais notável e poderosa se, tal como se encontra unida com a dialéctica no mesmo ramo, assim igualmente a ela se juntar mediante o estudo e o desvelo. Sem ela os que correm os estádios das demais ciências não só não podem alcançar qualquer meta, como também claudicam e falha, a meio da carreira.").

B)

[Fernandes; 26, cf. supra, p. 158] Atque, ut alios omittam, numquam certe Seruius ille Sulpicius in iuris prudentiae studio tam excellens exstitisset nisi (ut cum M. Tullio loquar) artem hanc, omnium artium maximam et quasi lucem, ad ea quae ab

O próprio Pedro Fernandes, porém, na p. 3 (cf. supra p. 132) da dedicatória que precede a edição da sua Oratio, é mais parco em detalhes, pois limita-se a consignar: Cum in hanc tuam, Rex inuictissime, florentissimam Academiam e Gallia uenissem ibique Iuris studia, quibus iam inde ab aliquot annis eram initiatus, prosequerer. ("Rei nunca vencido, tendo eu vindo da França para esta vossa florentíssima Universidade e prosseguindo aqui os estudos de Direito, nos quais já fazia alguns anos que me tinha iniciado.”). 
aliis tractabantur et respondebantur adiunxisset. ("E, para não referir-me a outros, nunca certamente aquele célebre Sérvio Sulpício se teria mostrado tão avantajado no estudo da jurisprudência se não (para me servir das palavras de Marco Túlio) tivesse aplicado esta arte, que é a maior e uma espécie de lâmpada de todas as artes, àquilo que as outras tratavam e asseguravam.").

[Pinto, 11; cf. infra, p. 404] Numquam Accursius ille uester - uobis loquor, iure consulti - tantum nomen in iure ciuili consecutus fuisset nisi artem banc, artium ceterarum lucernam, ad "obscurissimas ciuilium quaestionum tenebras", ut ille appellat, adiunxisset. ("Nunca aquele vosso célebre Acúrsio - e estou a dirigir-me a vós, jurisconsultos - teria alcançado tamanho renome no direito civil se não tivesse aplicado esta arte, que é a lâmpada das restantes artes, às "trevas cerradíssimas" (é assim que as caracteriza) das questões civis.). ${ }^{84}$

C)

[Fernandes, 28; cf. supra, p. 160] Et quoniam, ut initio dicebamus, excellens hoc animal corpore infimo et caduco constabat, diuino munere est hominibus medicina concessa, quae circa corpus ipsum uersaretur illudque non solum ab aduersa ualetudine conseruaret, sed iam lapsum in pristinam sanitatem reduceret. Atque ideo non immerito ab Herophilo medicina scientia salubrium et insalubrium et neutrorum dicta est. ("E porque, consoante dizíamos no princípio, este animal superior estava feito de um corpo muitíssimo fraco e perecível, por mercê divina foi concedida aos homens a medicina, para que ela se ocupasse acerca do próprio corpo, e não só o preservasse da enfermidade, mas também, uma vez ele enfermo, o fizesse recobrar a saúde. E por isso não foi sem razão que Herófilo chamou à medicina a ciência do saudável, do insalubre e do indiferente.").

[Pinto 16; cf. infra, p. 418] Quae, quoniam corpus hoc terreum, mortale, debile, caducum, quo compositi sumus, in uarios saepe morbos et languores $\left[\mathbf{1 6} \mathbf{v}^{\mathbf{}}\right]$ incidit, diuina nobis liberalitate concessa fuit ut non modo quae ad eius curationem pertinerent, cum aegrotum est, remedia suppeditaret, sed etiam sanum aduersus periculosos ictus et incertos euentus ualetudinis accomodato regimine tueretur. Quamobrem multi medicinam instaurandae et defendendae sanitatis artem, alii salubrium et insalubrium et neutrorum scientiam definierunt. ("Esta, porque este corpo de terra, mortal, frágil e perecível com que fomos feitos $\left[\mathbf{1 6} \mathbf{v}^{\mathbf{o}}\right]$ cai amiúde em diversas enfermidades e fraquezas, esta foi-nos concedida pela divina liberalidade para que, não só quando ele está doente lhe fornecer os remédios acomodados à sua cura, mas também prevenir o são contra os riscos e incertas eventualidades mediante um regime saudável apropriado. Por este motivo muitos definiram a medicina como a arte de restaurar e defender a saúde, ao passo que outros a caracterizam como a ciência do saudável, do insalubre e do indiferente.").

\footnotetext{
${ }^{84}$ Note-se a forma arteira como Pinto modifica o nome do jurista citado e, para tornar mais eficaz a táctica de despiste, inclusive lhe adscreve umas palavras que fazem pendant com a citação ciceroniana de Pedro Fernandes.
} 


\section{D)}

[Fernandes 34; cf. supra, p. 166] O excellentem sapientiam, quae nobis uitae auctorem demonstrat! O diuinam theologiam, qua una uel decrepita anicula instructa philosophorum omnium sapientiam potest superare! Haec prima philosophia est, haec philosophiae summa, haec ueritatis perfectio. "Oh excelente sabedoria, que nos mostra o autor da vida! Oh divina teologia, instruída pela qual até uma decrépita velhinha é capaz de superar a sabedoria de todos os filósofos! É esta a primeira filosofia, esta a súmula da filosofia, esta a perfeição da verdade.").

[Pinto, 19vº-20; cf. infra, p. 428] O diuinam sapientiam, quae manifeste Deum nobis demonstrat, per quam CHRISTVM Seruatorem nostrum, ex beata Virgine [20] natum, intelligimus! O excellentem ueritatis cognitionem, quae omnem sacrosanctae Scripturae ueritatem patefacit, figuram interpretatur mysteriaque omnia explanat, qua quidem uel rustici homines instructi summis illis excellentissimisque philosophis sapientiores et beatiores efficiuntur! O primam ac summam philosophiam, cui certe si reliquas artes et scientias comparemus, satis amplae ac ornatae nobis uideri debent, quod ei quasi diuino numine famulentur! ("Oh divina sabedoria, que claramente nos mostras Deus e através da qual compreendemos a Cristo nosso Salvador, nascido da bem-aventurada Virgem! [20] Oh excelente conhecimento, que patenteia toda a verdade da sacrossanta Escritura, interpreta as figuras simbólicas e explica todos os mistérios, instruídos pela qual até os homens ignorantes se tornam mais sábios e mais felizes do que os mais eminentes e mais extraordinários filósofos! Oh primeira e suprema filosofia! Se com ela compararmos as restantes artes e ciências, certamente que nos devem parecer muitíssimo importantes e honradas porque, por assentimento divino, a servem como escravas.").

E)

[Fernandes, 37; cf. supra, p. 168] Cuius ut imperium iisdem finibus, quibus et terrarum orbis terminatum, ut excellentes ac magnificos ab extremis usque Indis partos triumphos praetermittam: illud certe praetermittere non possum quod, omnibus his contemptis, aliunde gloriam multo solidiorem sibi existimauit comparandam uoluitque uniuersam suam Lusitaniam, quemadmodum ab hostibus, ita etiam ab omni barbarie liberatam. Quod ut efficeret academiam hanc uniuersi terrarum orbis florentissimam constituit [...]. ("Para não me referir ao seu império, que tem por limite as mesmas fronteiras da Terra, nem aos extraordinários e grandiosos triunfos incessantemente alcançados sobre os remotos Indianos: certamente não posso deixar de me referir ao facto de que, desprezando tudo isto, considerou que lhe cumpria obter alhures uma glória muito mais sólida e quis que todo o seu Portugal da mesma maneira que dos inimigos, assim também ficasse livre de toda a casta de barbárie. Para levar isto a cabo, fundou esta academia, a mais florescente de todas as que existem no mundo [...].").

[Pinto, 20; cf. infra, p. 428] Cuius [...] ut imperium, cui totum fere orbem terrarum subiectum habet, praetermittam: illam certe multo maiorem is et ampliorem laudem praetermittere non possum quam communi hominum consensu consecutus est, quod 
academiam hanc, omnium quae in toto terrarum orbe sunt florentissimam, constituit, in quam sapientissimos et grauissimos doctores ex omni fere Europa conuocauit, ut praeclara Lusitanorum suorum ingenia sanctissimis etiam litteris exornaret, quae paratissima ad militandi scientiam habuisset. ("Para não me referir [...] e ao seu poder, sob o qual mantém quase a Terra inteira: certamente não posso deixar de me referir a um motivo de louvor, muito maior e mais glorioso do que estes, e que alcançou por consenso comum dos homens por ter fundado esta academia, a mais florescente de todas as que existem no mundo, para a qual chamou os mais sábios e mais prestigiados mestres de quase toda a Europa, a fim de também munir com as santíssimas letras as brilhantes inteligências dos seus portugueses, que tivera muito bem preparadas para a ciência da guerra.").

3. Nas anotações procurámos sobretudo mostrar de que maneira António Pinto se insere na tradição da oratória académica nacional da primeira metade do século XVI, para o que indicámos ou transcrevemos todas as passagens dos seus antecessores em que muito provavelmente se inspirou ou buscou referências culturais. Sem termos pretendido ser exaustivo, também fizemos alguma pesquisa nos principais repositórios enciclopédicos então disponíveis e incessantemente manuseados, da qual algumas anotações darão a devida conta. Desta maneira terá o leitor a possibilidade de acercar-se dos processos de trabalho usados pelo nosso Autor e pela maior parte dos seus confrades, o que salutarmente contribuirá para relativizar a impressão de omnímodo saber que muitos deles nos podem deixar.

O exemplar da Oratio de que nos servimos encontra-se depositado, sob a cota Y'- 3-58, na Secção de Reservados da Biblioteca Municipal do Porto. No estabelecimento do texto latino que aqui apresentamos - e em todas as transcrições de textos latinos que efectuámos - corrigimos gralhas evidentes de impressão, uniformizámos a ortografia e pontuação e, quando necessário, abrimos parágrafos. Nas citações que fazemos das outras orações académicas reportamo-nos à paginação das primeiras edições, sendo que, relativamente àquelas que integram o presente volume, remetemos simultaneamente para as respectivas páginas dele mesmo. 
(Página deixada propositadamente em branco) 
TEXTO E TRADUÇÃO 


\title{
ORATIO \\ DE SCIENTIARVM OMNIVM \\ MAGNARVMQVE ARTIVM LAVDE
}

\author{
$\mathrm{AB}$ \\ ANTONIO PINTO \\ HABITA APVD VNIVERSAM \\ CONIMBRICENSEM ACADEMIAM \\ CALENDIS OCTOBRIS ANNO DOMINI 1555
}

Ad Illustrissimum Ioannem

Ducem Daueiro

CONIMBRICAE

Apud Ioannem Aluarum

typographum Regium 


\section{ORAÇÃO \\ EM LOUVOR DE TODAS \\ AS CIÊNCIAS E DAS GRANDES ARTES}

PRONUNCIADA POR

ANTÓNIO PINTO

\section{DIANTE DE TODA A ACADEMIA CONIMBRICENSE \\ NO $1^{\circ}$ DE OUTUBRO DO ANO DO SENHOR DE 1555}

Dedicada ao Ilustríssimo Senhor D. João, Duque de Aveiro

EM COIMBRA

Nas oficinas de João Álvares

Tipógrafo Régio 
$\left[\mathbf{1} \mathbf{v}^{\mathbf{o}}\right]$

\author{
QVAm Illvstrissimo Lavdatissimoqve DOMino IOANNi, \\ DVCi DE AVEIRO PRIMO, \\ Antonivs Pintvs CVM Veneratione Magna S.
}

Cum postularent amici, dux quam illustrissime, ut orationem, quam de scientiarum commendatione Calendis Octobris publice habueram, uellem emittere, primum equidem recusaui, ueritus ne, emissa illa oratione, quam nec tempore satis nec otio mentis adiutus (quae duo scis ad scribendi studium maxime requiri), sed partim dolore, partim negotio impeditus composueram, temere in uaria hominum iudicia diuersasque uoluntates inciderem. Nam, cum Idibus Augusti infaustam sane et acerbam de obitu fratris patruelis mei Ferdinandi de Campo, in quo et amorem et spem collocabam, epistolam accepissem, confestim ad eius sororem Leonoram, quae me arcessierat, profectus sum, ut ad eius negotium apud serenissimum regem conficiendum, cuius pro incredibili pietate et beneficentia tua patrocinium ac protectionem suscepisti, omnia tuo iussu praepararem.

Sed, cum postulantibus amicis rem ut sibi uidebatur honestam resistere non possum, tuo fretus praesidio, princeps maxime, hoc publicae editionis periculum subiuit.

Itaque paruum munusculum tibi multis de caussis offerre sum ausus: tum quia te studiorum omnium egregium et laudatorem et patronum academia nostra nacta est, ita ut quicquid sit de scientiarum laude tuo nomine consecratum non dubitem quin et placide accipias et iucunde ac alacri animo perlegas, tum quod hunc ingenioli mei fructum, quantuluscumque est, tuo tibi iure referre debui, nam quotiens in regiam tuam me conferebam ad sororia negotia opem expetens, totiens clarissimum os tuum et iucundissimum, in quo tantum ingenii et eruditionis lumen apparet, me maxime ad scribendum illustrabat; accedit etiam te illis uirtutibus, quas in optimo principe inesse oportet, humanitate et beneficentia, praestantissimum esse. 
$\left[\begin{array}{ll}1 & \left.\mathbf{v}^{\mathbf{o}}\right]\end{array}\right.$

\section{Com Grande Respeito António Pinto Envia SAudações AO IlustrísSimo E MUI AFAMAdo SENHOR D. JOÃO, Primeiro Duque de Aveiro. ${ }^{1}$}

Ilustríssimo duque, tendo-me os amigos pedido que quisesse dar a lume a oração que, em louvor das ciências, eu pronunciara em público no $1^{\circ}$ de Outubro, a minha primeira reacção foi recusar, temendo que, uma vez publicada aquela oração, para cuja composição não só não dispusera de tempo suficiente nem tivera o concurso da tranquilidade de espírito (requisitos ambos que, consoante sabeis, sobremaneira se requerem para a actividade literária), mas também me vira embaraçado em parte pelo desgosto e em parte por ocupações, afrontaria de modo temerário os juízos variados e as diversas disposições de espírito dos homens. É que, como tivesse recebido a 13 de Agosto uma assaz triste e dolorosa carta noticiando a morte do meu primo co-irmão Fernando do Campo, em quem depositava afecto e esperança, de imediato parti a encontrar-me com a sua irmã Leonor, que me chamara, a fim de, para tratar diante do sereníssimo rei dos interesses dela, cujo patrocínio e defesa, em conformidade com a vossa excepcional humanidade e bondade, tomastes a vosso cargo, tudo aprontar segundo as vossas ordens.

Mas, uma vez que não posso resistir a amigos que me pedem uma coisa que parecia honrosa, apoiando-me na vossa ajuda, nobilíssimo senhor, arrostei este risco de sair à luz pública. E assim atrevi-me, por muitas razões, a oferecer-vos um pequenino presente: não apenas porque a nossa academia encontrou em vós um egrégio apologista e patrono de todos os estudos, de tal maneira que não duvido de que acolheis de bom grado e ledes com alegria e entusiasmo tudo que se vos dedique acerca do louvor das ciências, ${ }^{2}$ mas também porque com toda a justiça vos deveria devolver como vosso este fruto do meu parco engenho, por poucochinho que ele valha, porquanto, todas as vezes que me dirigia ao vosso paço, esperando ajuda para os assuntos da minha prima, sempre a vossa nobilíssima e ameníssima boca, que dá mostras de tamanho brilho de inteligência e erudição, sobremodo me inspirava para escrever; acresce também que vós vos singularizais por aquelas virtudes que melhor quadram ao príncipe perfeito: a afabilidade e a bondade. 
Accipiens igitur hanc oratiunculam, quia parua tuo nomini consecrata

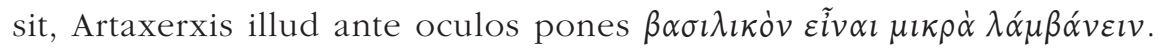

Leonorae sororis opitulaberis, cuius equidem, nisi eam praesidio haberes, grauius miseriam et orbitatem, quam fratris desiderium, deplorarem; opitulandi munus recordabere te, cum princeps natus sis, a Deo Optimo Maximo accepisse.

Vale, dux felicissime, Deumque precor ut maximam nominis tui amplitudinem, cum illustrissima natorum tuorum prole, diutissime felicissimeque conseruet.

Conimbricae, Idibus Octobris. 
Por conseguinte, ao aceitardes este pequeno discurso, porquanto, embora de somenos, vos está dedicado, lembrar-vos-eis daquele dito de Artaxerxes: É próprio do rei receber coisas pequenas. ${ }^{3}$

Acudireis à minha prima Leonor, de quem, se a não tomardes sob a vossa protecção, estou certo de que mais deplorarei a miséria e desamparo do que me punge a saudade do irmão; lembrai-vos que, ao nascerdes príncipe, recebeste de Deus Óptimo Máximo a obrigação de socorrer.

Ficai de saúde, felicíssimo duque, e rogo a Deus que, com imensa prosperidade e incessantemente, conserve o máximo prestígio da vossa nomeada, em companhia da ilustríssima prole dos vossos filhos. ${ }^{4}$

Em Coimbra, 15 de Outubro. 
$[\mathbf{2}]$

\section{ORATIO DE SCIENTIARVM OMNIVM \\ MagnarvmQve ARTivm LAVDE}

Quam uellem, rector dignissime, patres conscripti, Georgi illustrissime, uiri nobilissimi, ut quae duae res ad dicendum maxime ualent, eloquentia et auctoritas, has pro me hodierno die hoc uestro ornatissimo consessu, hac coniunctissima corona facere uiderem. Verum, cum nec ingenio, nec studio, nec doctrina quibus illa comparantur, satis possim, nullae sunt caussae quibus ego uel aliquam de me ad dicendum confidentiam concipiam, uel, si temeritate aliqua impulsus, conceperim, non deponendum existimem. $\mathrm{Nec}$, mehercle, dubium esse puto quin uobis hodie et temerarius et iuuenilis cuiusdam arrogantiae appetens esse uidear, quod huius loci auctoritatem contingere ausus fuerim, quem solent summi et eloquentissimi oratores tantum conscendere, quorum eximia dicendi uis, cum rerum pondere, sententiarum grauitate, uerborum copia et suauitate coniuncta, satis superque affirmare potest quam cum illis nullo modo sim comparandus.

Orarunt ex hoc loco permulti ingenio et industria uiri atque ita orarunt ut quotiens eorum orationes, ex quibus tantum audiendo cepistis uoluptatis, memoria complectimini, totiens illos non solum summe laudetis, uerum etiam dignissimos esse arbitremini in quos amplissima beneficia conferantur.

O me miserum, o me infelicem si nunc quis uestrum secum cogitet: "Vnde nobis tantum orator? Quid audacissimus iste? Quid post tam egregios et suaues oratores dicere potest? Quid, [2 $\left.\mathbf{v}^{\mathbf{0}}\right]$ nisi quod humili uulgo dignum sit, agricolarum et opificum turba?" Quamobrem non semel mecum cogitaui utiliusne fuisset mihi rem tantam et quae tantis ingenii et eloquentiae uiribus indiget numquam suscipere, an, temere a me suscepta, incurrere in reprehensionem doctorum hominum atque prudentium: eoque magis quod me hodie, hominem ignotum nec satis in dicendi usu et exercitatione uersatum, non modo nullam ad tantarum rerum parem orationem afferre posse, sed etiam aliquam inanem gloriolam quaerere existimabitis. 


\section{ORAÇÃO EM LOUVOR DE TODAS AS CIÊNCIAS E DAS GRANDES ARTES}

Digníssimo reitor, ${ }^{5}$ membros do senado académico, ilustríssimo Senhor D. Jorge, ${ }^{6}$ nobilíssimos varões, quanto desejaria que aquelas duas coisas que mais importam para discursar, a eloquência e a autoridade, as visse no dia de hoje militar a meu favor nesta vossa distintíssima assembleia e neste auditório estreitamente unido. Na verdade, uma vez que não possuo em abastança nem as capacidades intelectuais nem o estudo nem o saber com que se adquirem aqueles dois atributos, não existem quaisquer motivos que me levem a acalentar alguma confiança acerca das minhas capacidades oratórias ou a deixar de pensar que não devo pô-la de parte, se, impelido por algum arrojo temerário, chegar a acalentá-la. Nem, por Deus, me restam quaisquer dúvidas de que hoje vos pareça ser atrevido e dominado por uma espécie de arrogância juvenil, por ter tido a ousadia de ocupar este lugar prestigioso, ao qual costumam subir somente os melhores e mais eloquentes oradores, cujo excepcional vigor de elocução, unido à grande soma dos factos, à gravidade das sentenças, à riqueza e elegância de vocabulário, de sobejo e por demais pode asseverar o quanto é impossível comparar-me com eles.

Do alto deste lugar discursaram muitos varões dotados de inteligência e zelo e discursaram de modo tal que sempre que recordais os seus discursos, que como ouvintes vos causaram tão grande deleitação, não só os louvais muitíssimo, como também os estimais como totalmente merecedores de se lhes atribuírem enormes mercês.

Pobre e modinho de mim, se agora algum de entre vós pensar para consigo: "Donde nos vem semelhante orador? Que é que esse homem atrevidíssimo poderá dizer, depois de tão excepcionais e elegantes oradores? Quê, [ $\mathbf{2} \mathbf{v}^{\mathbf{0}}$ ] senão coisas apropriadas para a populaça e para a turba dos agricultores e dos artífices?" Por esta razão, pensei mais de uma vez se teria sido mais útil nunca me ter abalançado a uma empresa tamanha e que requer tão grandes recursos de engenho e inteligência, ou, abalançando-me a ela de modo temerário, incorrer na repreensão dos homens sábios e prudentes: e tanto mais que vós pensareis que eu hoje, homem desconhecido e não suficientemente versado na prática e exercício da oratória, não só sou completamente incapaz de pronunciar um discurso adequado a tão grandes matérias, mas também procuro alcançar alguma vã gloriosa. 
Forsitan quaeratis a me qui tantus iste timor sit, quae tanta dicendi formido, praesertim cum de eiusmodi re dicendum sit, in qua nemini deesse posse uideatur, oratio, quo in loco eorum oculos in me coniectos habeo et aures attentas quorum beneuolentiam et fauorem erga omnes huius loci et caussae oratores parietes, mehercle, iam huius atrii posse loqui uidentur: huic ego quaestioni, si qua forte apud uos fuerit, facile respondere possum, eoque facilius quod uos non ignorare puto quam ardua, quam difficilis, quam periculosa res sit, eum, cui, cum aliqua praestantis ingenii facultas et usitata dicendi consuetudo desit, uelle tamen, hoc plenissimo theatro, summas artes atque scientias oratione consequi apud sapientissimos doctores summosque philosophos, quorum animos adhuc illo magno et suaui sapore, quem ex aliorum ante orationibus acceperunt, imbutos et perfusos esse credendum est.

Mouet me quoque atque a dicendo deterret hominum uaria ac dissimilis in iudicando natura, adeo ut perbeati mihi uideri soleant qui eum in dicendo cursum tenere possunt, quo istas ingeniorum uarias nimiumque discrepantes inter se sententias, tamquam uadosas aliquas Syrtes euadant.

Quo igitur, patres conscripti, cum tanto rerum onere [3] confugiam? Quod adminiculum petam? Quem baculum hoc orationis cursu suscipiam? Nescio profecto si me hodie illa uestra humanitate, quae tam multis hoc loco et hac caussa auxilio fuit, destituendum putatis. Quare uos oro atque obsecro, humanissimi uiri, ut me quoque, sicut alios huius rei elocutores, dignum existimetis cui bona cum uenia et attentione faueatis.

Atque, ut iam posito ante oculos diuino numine ad rem ipsam, quae est propria nostrae orationis, aggrediar operae pretium uobis facturus uidebor,

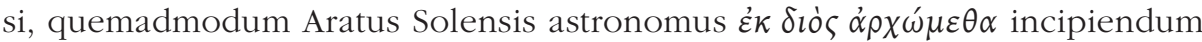
putauit, sic ego ab illo principe Deo, rerum omnium parente, narrationis huius initium ducam.

Summus ille, quem plerique ueterum philosophantium inuestigare et cognoscere potuerunt, colere, ut ait Beatus Paulus, ac uenerari nemo, mundum hunc, cuius ambitu uinciuntur omnia, tanta conuenientia tantaque pulchritudine composuit ac perfecit ut non modo ob id kó $\sigma \mu o v$, hoc est, "ornamentum" ueteres Graeci appellauerint, sed etiam praestantem aliquam aeternamque naturam esse crediderint, a qua gubernaretur. Huius infimam hanc partem, quae terram dicitur, in media totius mundi sede locauit. Cuius cum uberes agros considero, lenes fluuios, fecundas arbores, uarios et copiosos fructus, gelidos ac perennes fontes, reconditas etiam auri et argenti diuitias, uolucrum dulces cantus, sic afficior profecto ut amorem et beneficentiam Dei erga nos non facturam mundi perspicere uidear. Haec nos, quemadmodum a Plinio dictum est, non solum, cum nascimur, 
Talvez me pergunteis que temor e medo tamanhos são esses de discursar, principalmente sendo certo que o discurso há-de ser acerca de uma matéria tal em que parece que as palavras não podem faltar a ninguém, neste lugar em que tenho fitos em mim os olhos e os ouvidos de pessoas de cuja benevolência e simpatia para com todos os oradores deste lugar e tema já as paredes deste átrio, por Deus, parecem poder dar testemunho: a esta pergunta, se por acaso se puser entre vós, posso responder facilmente, e com tanto maior facilidade porque julgo que vós não ignorais como é coisa árdua, como é coisa difícil e como é coisa arriscada, que o homem, a quem faltam qualquer capacidade de inteligência superior e a prática de discursar, mesmo assim queira discorrer oralmente, neste teatro repleto, acerca das artes e ciências mais elevadas, diante dos mais sábios mestres e dos mais insignes filósofos, cujos espíritos é de crer que ainda se encontrem embebidos e inundados por aquele intenso e saboroso gosto que anteriormente sentiram com os discursos dos outros.

Também me afasta e desvia de discursar a natureza dos homens, variada e dissemelhante no julgar, a tal ponto que me costumam parecer muito felizes os que na oratória conseguem manter aquele rumo que lhes permite esquivar, como se se tratasse de aparceladas sirtes, essas opiniões variegadas e sobremaneira opostas entre si.

Por conseguinte, caros membros do senado académico, onde me refugiarei com uma carga [3] tão pesada? Que ajuda pedirei? A que bordão me arrimarei nesta jornada oratória? Na verdade que não sei se achais que eu hoje mereço ser privado daquela vossa indulgência que a tantos acudiu neste lugar e nestas circunstâncias. Por isso, indulgentíssimos varões, rogo-vos e suplico-vos que também a mim, à semelhança dos outros prelectores deste assunto, me considereis merecedor de me favorecerdes com a vossa complacência e atenção.

E, a fim de, posta já diante dos olhos a majestade divina, me ocupar propriamente do assunto, parecer-vos-á que há-de valer a pena se eu, tal como Arato, astrónomo de Solos, considerou que cumpria que "começássemos por Zeus", ${ }^{7}$ assim eu principie esta prelecção a partir daquele soberano Deus, Pai de todas as coisas.

Aquele supremo Deus, a quem, segundo São Paulo, muitos dos antigos filósofos puderam investigar e conhecer, mas nenhum adorar, criou e aperfeiçoou este mundo, em cujo âmbito se contêm todas as coisas, ${ }^{8}$ com tamanha harmonia e com tamanha formosura que não só por isso mesmo os antigos Gregos lhe deram o nome de

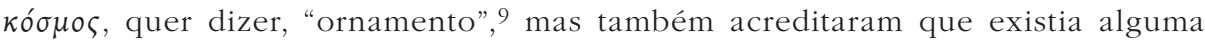
natureza superior e eterna que o governava. À parte mais pequena deste cosmos, a que se chama terra, situou-a no meio de todo o mundo. Quando atento nos seus férteis campos, nos seus rios amenos, nas suas bondosas árvores, nos seus variados e copiosos frutos, nas suas frescas e perenes fontes, nas suas riquezas ocultas tanto de ouro como de prata, nos doces cânticos das aves, de tal maneira fico totalmente impressionado que me parece contemplar o amor e bondade de Deus para connosco e não a obra do mundo. ${ }^{10}$ Esta, consoante diz Plínio, não apenas, quando nascemos, 
primum excipit suo gremio, sed natos iam nutrit ac sustentat. Qua de caussa existimo communem hominum ac deorum matrem poetarum carminibus fuisse appellatam.

Terrae finitimam posuit aquam illo immenso et spatioso [3 $\mathbf{v}^{\mathbf{o}}$ ] mari quod magnum et oceanum dicitur, contentam atque coercitam ea lege ut, quamuis uentis impellatur et aestu continuo fluctuet, non possit tamen hanc partem terrae aquis occupare quam diuina Prouidentia, rerum omnium moderatrix, nobis ceterisque animantibus, quae terrestria sunt, ad uitam tuendam et conseruandam separauit. Haec inter alias commoditates semina uisceribus terrae conglutinat et terram ipsam ad procreandas fruges irrigat ac perfundit: quae res illum Asianum Thaletem impulit, qui primus in Graecia sapientis nomen adeptus est, ut aquam rerum omnium, quae natura fiunt, et principium et alimentum putarit.

Post aquam est tertium corpus locatum, qui a Latinis et Graecis uno nomine "aer" appellatur. Vitalem hunc nobis dedit et per cuncta rerum genera meantem fecit.

Huic quartum apposuit ignem, quem, si e ratione rerum sustuleris, nec uita hominum, quae plurimum hoc utitur, nec rerum ipsa natura permanere et conseruari poterit: est enim in eo mouendi ac efficiendi quaedam uis, unde moti sunt priores, ut lucida illa et rotunda sidera sempiternos ignes appellauerint, ex quibus non solum ea quae genita sunt in mundo continuum et igneum quemdam influxum accipere, sed etiam animos hominibus prouenire rebantur.

Praeter haec rerum prima initia, quintum corpus constituit inferiorum certe natura et perfectione multum dissimile, quod caelum dicitur, animatum ac diuinum, quod non modo templum sibi esse uoluit, e quo res humanas prospiceret, sed etiam mundi huius inferioris regimen et gubernaculum: immensum est, conspicuum, clarum et omni conflictione liberum, elegantia summa et perfectione absolutum et, quod admirabile eius artificium demonstrat, lucidissimis illis astris tamquam smaragdis et pyropis quibusdam caelatum ac splendens, quamobrem [4] "caelum" dictum arbitratur Latinorum sapientissimus Varro fabricato et adornato mundo. Animal, quod tantarum rerum aspectu et ornamento caperetur, e limo terrae procreauit sensu ac intelligentia praeditum, quem uocauit hominem, cuius caussa cuncta alia ab ipso effecta fuisse non ignoramus.

Atque hunc, cum reliquis animantibus, quae uentri prona et oboedientia sunt, uoluisset ipse anteferre, duobus uestiuit ornamentis, animo et corpore. Atque haec ita coniunxit ut animal hoc tam excellens, tam diuinum, sensum omnem animi sui e miseris et mortalibus terris ad cognoscendum et amandum Deum educeret. In quo diuus Augustinus totam uim et rationem hominum posuit, ut Deum auctorem uitae et sempiternae ac suauissimae felicitatis datorem perfecte cognoscerent eumque, cum satis 
logo nos acolhe no seu seio, mas depois de nascidos alimenta-nos e sustenta-nos. ${ }^{11}$ Razão pela qual me parece que os carmes dos poetas a designaram por mãe comum dos deuses e dos homens. ${ }^{12}$

Contígua à terra colocou a água, com aquele imenso e dilatado $\left[3 \mathbf{v}^{\mathbf{0}}\right]$ mar, a que se chama grande e oceano, subordinada e sujeita a uma lei tal que, ainda que seja batido pelos ventos e incessantes marés o agitem, todavia não pode ocupar com as águas esta parte da terra que a divina Providência, que governa todas as coisas, nos destinou, a nós e a todos os demais animais terrestres, para nela sustentarmos e preservarmos a nossa vida. Entre outras vantagens, ela encerra as sementes nas entranhas da terra e rega e inunda a mesma terra para produzir as searas: facto este que impeliu o asiático Tales, que foi na Grécia o primeiro a obter o título de sábio, ${ }^{13}$ a considerar a água como o princípio e o alimento de todas as coisas que a natureza produz. ${ }^{14}$

Depois da água colocou-se o terceiro corpo, que Gregos e Latinos designam com o mesmo nome de "ar". ${ }^{15}$ Deu-no-lo vital e fez que circulasse por toda a espécie de coisas.

A este ajuntou o quarto, o fogo, o qual, se se suprimir da ordem das coisas, tornará impossível que a vida dos homens, que dele muito se servem, e a própria natureza, subsistam e se mantenham: é que nele existe uma certa potência para mover e produzir, da qual receberam movimento os primeiros, de maneira que àqueles brilhantes e redondos astros se chamaram fogos sempiternos, julgando que deles não só recebiam uma espécie de influxo contínuo e ígneo as coisas que nascem no mundo, mas também provinham os espíritos para os homens.

Além destes primeiros inícios das coisas, criou um quinto corpo, animado e divino, certamente em natureza e perfeição muito diferente das mais baixas, e ao qual se chama céu, que quis que fosse para si um templo de onde pudesse vigiar os negócios humanos, mas também direcção e leme deste mundo inferior: é imenso, brilhante, claro e isento de toda a espécie de contendas, construído com a máxima formosura e perfeição e, o que demonstra o seu admirável lavor, ataviado e resplandecente com aqueles luzidíssimos astros, como se fossem uma espécie de esmeraldas e piropos, razão pela qual [4] Varrão, o mais erudito dos Latinos, pensa que se dá o nome de "céu" ao mundo trabalhado e adornado. ${ }^{16}$ Ao animal que criou com o barro da terra, dotado de sentidos e inteligência para que fosse seduzido pela aparência e atavio de tão grandes coisas, chamou-lhe homem, não desconhecendo nós que tudo o mais foi feito por causa dele.

E, como tivesse querido antepô-lo aos restantes animais, que se inclinam e obedecem ao ventre, revestiu-o com dois atavios, no corpo e no espírito. E de tal sorte os ajuntou que este animal tão excelente e tão divino desviou da mísera e mortal terra todos os sentidos do seu espírito para aplicá-los a conhecer e amar a Deus. Santo Agostinho colocou toda a essência e natureza dos homens em reconhecerem perfeitamente a Deus como autor da vida e dador da sempiterna e suavíssima felicidade e em adorá-Lo com piedade e fé, depois de plenamente O terem 
cognitum et perspectum haberent, summa cum pietate et fide ueneraretur. Atque ad hunc maxime finem omnia tum corporis, tum animi instrumenta concessit: nam corpus ipsum, ut illud primo consideremus, ita figurauit et composuit ut et pulchritudine et uenustate et symmetria partium inter se facile reliquis corporibus antecellat. Et, cum ceterorum animalium corpora abiecta et inclinata fecisset ad pastum, homini sublatum et erectum dedit, ut posset ad eum locum, unde sibi animus datus est, tamquam ad propriam cognationem futurumque domicilium oculos eleuare. Corpori sensus dedit, quos non imbecilles aut fallaces aliquos nuntios, sed ueros iudices et interpretes rerum subiectarum haberemus. Et quoniam ad ducenda etiam intelligendarum rerum simulacra nobis concessi sunt, eos idcirco aliorum animalium sensibus longe praestabiliores ac utiliores $\left[\mathbf{4} \mathbf{v}^{\mathbf{o}}\right]$ esse uidemus.

Praeter haec illustria et magnifica corporis ornamenta, animum dedit caelestem, immortalem, diuinum, cui uniuersi corporis sensus tamquam proprio domino et imperatori parerent. Cuius quidem tanta praestantia est, tanta diuinitas, tanta cum Deo ipso similitudo et affinitas ut certe mihi ueteres illi sapientiae exploratores non tam laudandi uideantur quod immortalitatem illius argumentis et rationibus inuenerunt, quam admirandi quod ex diuina mente decerptum credentes cum nullo alio nisi cum Deo ipso comparandum esse censuerunt. In quo numero fuit Euripides ille Cretensis, qui animum hominis $\theta \varepsilon o ́ v$ appellare non dubitauit.

Ah quanto rectius hic quam Epicurus, tantorum malorum pater, quem suae uoluptatis esca ita irretiuit ut diuinum hominis animum non modo a natura corporis non separauerit, uerum etiam (quod "horresco referens", patres conscripti) cum corpore simul interire ac dissipari uoluerit. Igitur id uere mihi licet dicere, ex omnibus donis et ornamentis quae Deus Optimus Maximus in animum hominis contulit, illud maximum et clarissimum esse quod eum insatiabili quadam contemplationis et scientiae cupiditate et amore uestiuit. Sunt alia multa non mediocria eius officia, ut cogitare, prouidere, discere, docere, inuenire, amare, odisse, meminisse, uerum amare et cupere scientiam, hoc uero est quod hominem perfectum reddit et earum rerum, quae uitam beatam efficiunt, iam nunc, cum in terris moratur, participem.

Etenim ea lege sunt procreati homines - ad quam non docti, sed facti, non instituti, sed imbuti uidentur - ut nulla sit res non modo magna aliqua, quales sunt artes praeclarae et scientiae, sed etiam parua aut exigua quaeuis, cuius amore cognoscendae et auiditate non trahantur. Ad hanc [5] scientiae cupiditatem accedit quoque propensio quaedam animi et aptitudo, siquidem ad discendum et cognoscendum natura sumus prompti et affecti, nec enim est cur ea, quae apud Platonem in "Menone" scripta sunt, probare debeamus, cum ait animis humanis ab initio, cum in corpora ueniunt, 
conhecido e compreendido. E foi sobretudo com este fito que concedeu todos os dons, tanto os do corpo como os do espírito: com efeito, ao próprio corpo, para que nele atentemos em primeiro lugar, moldou-o e compô-lo de tal maneira que, pela beleza e simetria das partes entre si, facilmente se avantaja aos demais corpos. $\mathrm{E}$, tendo feito os corpos dos restantes animais abatidos e inclinados para o pasto, deu-o ao homem elevado e erecto, a fim de que pudesse, como para coisa sua e seu futuro domicílio, levantar os olhos para aquele lugar de onde lhe proveio o espírito. Deu sentidos ao corpo, para que nos servissem, não de mensageiros fracos ou enganosos, mas de avaliadores e intérpretes verdadeiros das coisas que se nos apresentam. E visto que nos foram concedidos para nos transmitirem também as imagens das coisas inteligíveis, por isso vemos que são de longe mais excelentes e [4 $\mathbf{v}^{\mathbf{0}}$ ] úteis que os sentidos dos outros animais. ${ }^{17}$

Além destes ilustres e magníficos ornamentos do corpo, deu uma alma celestial, imortal e divina, para que a ela, como a seu próprio amo e senhor, obedecessem todos os sentidos do corpo. A qual, certamente, possui tamanha superioridade, tamanha divindade e tão grande semelhança e afinidade com o próprio Deus que me parece que aqueles antigos batedores da sabedoria não merecem ser louvados tanto porque descobriram a sua imortalidade com argumentos e raciocínios, quanto devem ser admirados por, crendo que ela fora retirada do entendimento divino, terem julgado que não cumpria ser comparada com nenhuma outra cousa senão com o próprio Deus. A este número pertenceu o célebre Eurípides cretense, ${ }^{18}$ que não duvidou em chamar "deus"19 ao espírito do homem.

Ah, quanta mais razão não teve ele do que Epicuro, progenitor de tão grande número de males, a quem de tal modo enleou o engodo do seu prazer que não só não separou a divina alma do homem da natureza corporal, mas também (algo que, ó membros do senado académico, "tremo de horror ao contá-lo") ${ }^{20}$ pretendeu que morre e se desata juntamente com o corpo. Portanto, é-me lícito dizer que, de entre todos os dons e ornamentos que Deus Óptimo Máximo colocou no espírito do homem, o maior e mais ilustre é tê-lo revestido de uma espécie de insaciável desejo e amor de contemplação e de ciência. Possui ele muitas outras funções nada desprezíveis, como sejam o pensar, o prever, o aprender, o ensinar, o descobrir, o amar, o odiar e o lembrar, mas o amar e o apetecer a ciência - é isto na verdade o que torna perfeito o homem e o faz partícipe, já agora, enquanto permanece na Terra, daquelas coisas que tornam a vida bem-aventurada.

Efectivamente, a natureza com que os homens foram criados - e que não lhes parece ter sido ensinada, mas ser-lhes conatural, nem resultar da educação, mas ser-lhes ingénita - é tal que são arrastados pelo amor e avidez, não só de qualquer coisa elevada, como são as artes mais distintas e as ciências, mas igualmente de qualquer pequena ou exígua. A este [5] desejo de ciência acresce também um certo pendor e aptidão do espírito, visto que, por natureza, estamos inclinados e dotados para aprender e conhecer, pois não há razão para que devamos aprovar o que Platão escreveu no Ménon, quando diz que as almas humanas desde o princípio, 
ingenitam esse ac insitam rerum omnium sine doctrina cognitionem, nec nos, cum celeritate nimia et cursu ingenii res magnas ac innumerabiles consequimur, tum primum discere, sed reminisci ac recordari.

Quanto plus apud nos ualere debet Aristotelis summi in omni scientia uiri sententia - quem ego puto eamdem illam ingenii sui aciem, qua rerum omnium naturam uimque uiderat, ad intelligendam animi uirtutem et diuinitatem direxisse -, in quo non impressas aliquas, quemadmodum Platoni uisum est, et quasi consignatas rerum notiones esse uoluerit, sed ita rudem ac expertem initio nobis infundi ut eum cum tabula aliqua rasa et inculta, in qua nihil depictum signatumue est, comparandum putet.

Nec nos propterea naturam cum Plinio hominis nouercam appellemus, quae cum reliqua animantia sua quaeque per se munera tenere et scire uoluerit, alia uelocia, alia uolantia, alia uires habentia, alia natantia sponte nasci, hominem scire nihil, non fari, non ingredi, non uesci sine doctrina uidemus. Quae, quamquam ita se habent, illud tamen non mediocre nobis censendum est felicitatis humanae adiumentum esse quod animum talem acceperimus a natura ut ad omnes scientias et artes auidum eum et propensum habeamus.

O diuinam animi uirtutem! O caelestem et admirandam naturam, quam ideo concessit homini Deus ne, quem tam excellentem, sagacem, memorem, prouidum, rationis consiliique participem genuisset, eumdem praeclaro et diuino sapientiae munere priuare, uideretur. [5 $\mathbf{v}^{\mathbf{o}}$ ] Est enim sapientia ab illo immenso et immortali Deo omnium bonorum auctore profecta. Qua cum nihil melius, nihil praestantius, nihil ad omnes res tum publicas, tum etiam priuatas pertinentius nobis datum sit, diuinus Plato et inuentum et donum Dei appellare non dubitauit. Nec immerito: siquidem eam Salomon, omnium diuino munere factus sapientissimus, ait ex ore altissimi et supremi Dei prodiisse. Haec est, haec est data homini cultura ad omnia non modo radicitus uitia extrahenda, sed etiam ad fructus scientiarum et uirtutum capiendos.

Non possum ullo modo tacitus praeterire illam singularem ac paene diuinam Stoicorum sententiam, quibus tantum sapientiae nomen uisum est ut non solum inter eam et bonitatem discrimen nullum ponerent (eosdem enim sapientes et bonos uno nomine appellabant), sed etiam ex eorum uita qui sapientes essent, omnem tum animi, tum corporis perturbationem tollerent atque extirparent naturaque illud comparatum esse, sapientes nullo dolore, nulla cupiditate, nullo metu, nulla libidine nulloque aliorum etiam affectuum labefactari, uinci aut expugnari debere, sed, magnitudine consilii, humanorum casuum tolerantia, contemptione fortunae, uirtutis et sapientiae suae praesidio munitos, omnes harum rerum et perturbationum 
quando vêm para os corpos, possuem, sem ensinamento, um conhecimento ingénito e conatural de todas as coisas, e que, quando alcançamos grandes e inumeráveis coisas com excessiva celeridade e presteza da inteligência, não estamos a aprender, mas sim a relembrar e recordar. ${ }^{21}$

Devemos dar muito mais crédito à opinião de Aristóteles, o varão de maior autoridade em todas as ciências - o qual, na minha opinião, na compreensão da virtude e divindade da alma seguiu a inspiração daquela mesma penetração intelectual com que vira a natureza e essência de todas as coisas -, quando pretendeu e pensou que as noções das coisas não tinham sido como que impressas e gravadas, tal como pareceu a Platão, mas que, no início, o espírito nos é infundido tão informe e despojado que considera que deve ser comparado com uma tábua rasa e tosca em que nada se pintou ou gravou. ${ }^{22}$

Tão-pouco por esse motivo chamaremos, como Plínio, "madrasta do homem" à natureza, a qual, ao querer que os restantes animais cada um por si compreenda e saiba as suas funções, vemos que espontaneamente uns nascem velozes, outros voadores, outros possantes, outros nadadores, e que o homem nada sabe, não fala, não caminha e não se alimenta sem aprendizagem. Conquanto as coisas assim se passem, todavia devemos pensar que é um grande acréscimo para a felicidade humana o facto de a natureza nos ter dado um espírito caracterizado por tão grande avidez e propensão para todas as ciências e artes.

Oh divina virtude do espírito! Oh admirável e celestial natureza, que Deus concedeu ao homem para que não parecesse que privara do divino e ilustre dom da sabedoria alguém a quem criara tão excelente, perspicaz, memorioso, previdente e partícipe da razão e prudência. [5 $\mathbf{v}^{\mathbf{0}}$ ] É que a sabedoria provém daquele imenso e imortal Deus, autor de todos os bens. ${ }^{23}$ Uma vez que, de tudo que nos foi dado, nada há melhor do que ela, nem mais elevado, nem mais acomodado para todas as coisas, tanto públicas como privadas, o divino Platão não hesitou em designá-la como um "achado e dádiva de Deus". ${ }^{24}$ E com toda a razão: pois Salomão, tornado por mercê divina o mais sábio de todos, diz que ela nasceu da boca do altíssimo e supremo Deus. ${ }^{25}$ Ela foi dada ao homem em arrendamento, não só para que arrancasse de raiz os vícios, mas também para colher os frutos das ciências e das virtudes.

De modo algum posso passar em silêncio aquela extraordinária e quase divina opinião dos Estóicos, para os quais o nome de sabedoria parecia ter tamanho valor que não só não faziam qualquer distinção entre ela e a bondade (pois designavam com a mesma palavra os bons e os sábios), mas também suprimiam e extirpavam toda a espécie de perturbação, tanto de espírito como de corpo, da existência dos que eram sábios: opinião segundo a qual é em conformidade com a natureza que os sábios não devem ser abalados, vencidos ou subjugados por nenhuma dor, nenhum desejo, nenhum temor, nenhuma paixão e nenhum dos outros afectos, mas, protegidos pela grande prudência, pela constância em suportar as desventuras humanas, pelo desprezo da fortuna e pelo socorro da sua virtude e sabedoria, rechaçam todas as arremetidas e incursões destas coisas e perturbações. Cuido que 
impetus ac excursiones propulsare. Quamobrem arbitror fictis fabulis dixisse poetas, sapientiam e Iouis - 'Av $\delta \rho \tilde{\omega} v \tau \varepsilon \theta \varepsilon \tilde{\omega} v \tau \varepsilon \pi \alpha \tau \rho o ́ \varsigma$, ut ait Homerus -, cerebro fuisse natam, tum etiam saeua Gorgone, parma, hastaque trementi armatam, quae, quoniam in rebus bonis et expetendis maxima est, praeter omnes artes et uirtutes insignes, nos quoque docet et hortatur ut nostri cognitionem habeamus. Cuius uerbi tanta uis est, tanta dignitas ut illud non Chiloni quidem Lacedaemonio, a quo prolatum fuit, sed Delphico [6] Appollini tributum sit aureisque litteris in eius templo consecratum.

O magistra morum, sapientia, animi pabulum e caelo datum! O mater omnium artium et scientiarum! Quae, obsecro, praemia? Quas dignitates? Quos honores homines per te consequuntur? Quos tu amores tui? Quae desideria in animis nostris excitares si, ut inquit Plato, oculis corporeis cernereris? Huius studium, uiri nobilissimi, qui diligentissime et amantissime sequuntur, non solum mihi perbeati uideri solent, sed etiam proprio nomine philosophi appellantur. Quod nomen, ut ab honestissimo amore sapientiae ortum habet, sic certe omnium magnorum regum, ducum, imperatorum et eorum, qui in reipublicae administratione praeclarissime uersantur, nominibus anteferendum est.

Quae res, ut etiam exemplis utamur, illum Atheniensem Socratem tenuit iisdem in uestigiis immotum ac inconiuentem oculis in unum locum defixis

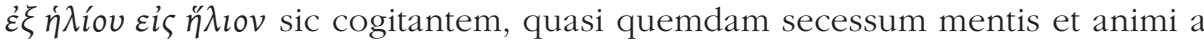
corpore fecisse uideretur, nisi studium sapientiae? In quo tantum modestiae seruauit ut ob id merito Appollinis oraculo omnium sapientissimus fuerit iudicatus.

Quae uis huius auditorem Euclidem Megarensem impulit ut, praeter grauissimum Atheniensium decretum, capitis sui periculum contemnens, Athenas noctu ad Socratem commearet, nisi ut noctis saltem aliquo tempore Socratis uoce et doctrina frueretur? Quid illa Platonis, quid Pythagorae peregrinatio? Quid Democriti obcaecatio, ne animum a cogitationibus alienaret, significat, nisi magnum et admirabile in is studium sapientiae fuisse? Quid de Alexandro dicam, qui tanti fecit studium sapientiae ut non imperio quidem suo, quod ille proeliis et uictoriis maximis per omnes totius orbis terrarum regiones dilatauit, $\left[\mathbf{6} \mathbf{v}^{\mathbf{o}}\right]$ non generis diuinitate, quo se Ioue satum saepissime gloriatus fuit, sed studio sapientiae se ceteris hominibus antecellere putauit?

Non possum hoc loco non commemorare, quoniam a uobis concedi, humanissimi auditores, tribuique sentio, Aegyptiorum hominum consuetudinem, quibus, cum adeo magnum et praestans philosophorum nomen uideretur, solis iis absolutis et illustribus uiris pro comperto habuerunt uniuersae rei publicae gubernacula esse concedenda. 
por este motivo disseram os poetas nas fingidas fábulas que a sabedoria nasceu do cérebro de Júpiter - "pai dos homens e dos deuses", consoante diz Homero ${ }^{26}$ -, já então armada de escudo, com uma cruel Górgona, e lança dardejante, a qual, porque é a maior das coisas boas e desejáveis, além de todas as artes e virtudes extraordinárias, também nos ensina e exorta a adquirirmos o conhecimento de nós mesmos. ${ }^{27}$ É tamanha a força, tamanha a dignidade desta sentença, que foi atribuída, não ao lacedemónio Quílon, ${ }^{28}$ que a proferiu, mas ao Apolo de Delfos, [6] e com letras de ouro consagrada no seu templo. ${ }^{29}$

Ó sabedoria, mestra dos costumes, alimento da alma dado pelo céu! Ó mãe de todas as artes e ciências! Pergunto: que prémios, que dignidades e que honrarias alcançam os homens por causa de ti? Tu, que amores por ti, que desejos não despertarias nas nossas almas, se, tal como diz Platão, fosses contemplada com os olhos do corpo? ${ }^{30}$

Nobilíssimos varões, os que se entregam com o máximo desvelo e amor ao estudo dela não só me parecem bem-aventurados, mas também é com toda a propriedade que são designados filósofos. Este título, assim como tem a sua origem no honestíssimo amor da sabedoria, da mesma maneira é indubitável que deve ser preferido aos títulos de todos os grandes reis, duques, imperadores e dos que gloriosamente se ocupam com o governo do Estado.

Para recorrermos também a exemplos, que coisa, senão o amor da sabedoria, manteve aquele célebre Sócrates ateniense imóvel na mesma postura e com os olhos abertos fixos num único ponto "do nascer ao pôr do Sol"31 de tal modo pensativo que quase parecia que o entendimento e a alma se tinham retirado do corpo? E neste amor manteve tamanha moderação que por esse motivo com toda a justiça o oráculo de Apolo o julgou como o mais sábio de todos. ${ }^{32}$ Que força impeliu um seu ouvinte, o megarense Euclides, a, desafiando um gravíssimo decreto dos Atenienses, sem olhar para o perigo da sua própria vida, durante a noite dirigir-se a Atenas ao encontro de Sócrates: que força o impeliu, senão o desejo de desfrutar, ao menos de noite, durante algum tempo da voz e dos ensinamentos de Sócrates? Que impeliu Platão e Pitágoras às célebres viagens que fizeram? Que significa a cegueira voluntária de Demócrito, ${ }^{33}$ a fim de não alhear o espírito da meditação, senão que nestes homens havia um grande e admirável amor pela sabedoria? Que hei-de dizer acerca de Alexandre, que tinha em tamanho apreço a sabedoria que considerou que se avantajava aos demais homens, não pelo seu império, que através de combates e vitórias inexcedíveis dilatou por toda a extensão da terra, [6 $\left.\mathbf{v}^{\mathbf{0}}\right]$ nem pela divindade da sua linhagem, em relação à qual mui amiúde se gloriou de ser rebento de Júpiter, mas pelo amor da sabedoria? ${ }^{34}$

Neste lugar não posso deixar de lembrar, pois sinto, indulgentíssimos ouvintes, que me permitis e concedeis licença, o costume dos Egípcios, aos quais a tal ponto lhes parecia superior e grandioso este título de filósofos que estavam convencidos de que o leme da totalidade do Estado só deveria ser entregue a estes perfeitos e ilustres varões. 
Mitto artium omnium et scientiarum studia; mitto legum instituta, quae omnia a philosophis inuenta, tractata, lecta, scripta et notata legimus. Quapropter a lacrimis me abstinere non possum idque uobis omnibus dolori esse puto, cum nomen hoc tam insigne, tam amplum odiis multorum deturpatum, negligentia fractum uideo, qui studium sapientiae, quod nobis praesidio uitae datum est, ut inane et perniciosum rei publicae repudiandum putant. Quam ob caussam plures reperimus qui non uera et immortalia bona, quales sunt artes praeclarae et scientiae, sed falsa, turpia et non permanentia studio et amore nimio sequantur.

Heu dementiam eorum qui tantopere fortunae ludibria expetenda putant! Quae qui expetunt, eos nullis artibus nullisque praeceptis eruditos cernimus, spe uaria semper et incerta pendenteis; quos omnes, cum iam se beatos, cum se florentes putant, fortuna ipsa, immutato rerum apparatu, misere deiicit atque prosternit. Alios etiam uidemus qui et ornamento domus et formae pulchritudine delectantur. Sed quid pulchritudo corporis, quid generis nobilitas, quid elegantia domus ad bene beateque uiuendum confert? Praeclarissimus est, ut scriptum habemus a Platone, thesaurus uirtus maiorum, at multo praeclarior Sthennio ${ }^{1}$ poetae uidetur maiores uir tutis gloria [7] et praestantia superare. Nam quem fructum nobis ea, qua multi abutuntur, nobilitas maiorum afferre potest? Quam non potius ignominiam aut dedecus, si improbi ac ineruditi sumus?

Diogenes, ille cynicus Alexandri contemptor, cum esset inuitatus a quodam, qui conspicuam satis et ornatam domum habebat, sputum exscreans in illum coniecit. Cum is aegre ferret: "nihil", inquit Diogenes, "in tota domo neglectum, nihil inornatum nisi te conspicio: nam parietes omnes egregiis picturis ornati sunt, pauimentum tesseris pretiosis exstructum, tectum mirabili artificio elaboratum, lectus et eius fulcra insignia, uasa aurea et argentea pura, te uero harum rerum omnium dominum omni squalore et situ contaminatum cerno."

Vtinam tantam uitae deformitatem tantamque imperitiam negligentia parentum non contraheremus! Quo tempore amplectenda sunt artium et uirtutum studia, tenera puerorum corpora deliciis et uoluptatibus corrumpi sinunt blandaque educatione uires omnes ingenii debilitari. Quamobrem mihi iure laudandus ille uidetur Solon sapientissimus, quod legem sanciuit ne quis patrem suum, a quo nullis disciplinis et uirtutibus traditus fuisset, alere et sustentare cogeretur.

Hinc satis sentire possumus, uiri nobilissimi, quam litterarum studium externis et fortuitis bonis praeferendum sit. Quod cum satis contemplaretur Boethius Seuerinus, maximus liberalium studiorum illustrator, eiusque bona

\footnotetext{
${ }^{1}$ Editio princeps: Stheneo.
} 
Deixo de parte os estudos de todas as artes e ciências; deixo de lado os ensinamentos das leis, que sabemos que todos foram descobertos, expostos, ensinados, escritos e comentados por filósofos. Razão pela qual não posso abster-me das lágrimas, e creio que a todos vós isso também causa desgosto, quando vejo este nome tão insigne e tão glorioso desonrado pelo ódio e abatido pela indiferença de muitos, que consideram que o estudo da sabedoria, que nos foi dado como sustentáculo da vida, deve ser rejeitado como inútil e prejudicial ao Estado. Por este motivo encontramos muitas pessoas que seguem com sobejo desvelo e amor, não os bens verdadeiros e imortais, como são as artes preclaras e as ciências, mas os falsos, vis e perecíveis.

Oh demência dos que cuidam que são tão apetecíveis os enganos da Fortuna! Vemos que aqueles que os perseguem não sabem quaisquer artes nem regras, sempre suspensos de uma esperança inconstante e incerta; a todos eles, quando já se julgam felizes e prósperos, a mesma Fortuna, mudando a aparência das coisas, abate-os e fá-los cair de modo lastimoso. Também vemos que outros se deleitam com os ornamentos da casa e a beleza física. Mas, para viver bem e com felicidade, de que serve a formosura corporal, de que serve a nobreza de linhagem, de que serve a elegância da casa? Consoante escreveu Platão, a virtude dos antepassados é um tesouro muito admirável, mas ao poeta Esténio ${ }^{35}$ parece-lhe muito mais admirável avantajar-se aos antepassados em glória [7] e superioridade de virtude. Com efeito, que benefícios nos pode trazer uma nobreza de antepassados, da qual muitos se servem? Não é antes ela ignomínia e desdouro, se nós somos desonestos e ignorantes?

Aquele célebre Diógenes, que mostrava desdém por Alexandre, ${ }^{36}$ tendo sido convidado por certa pessoa, que possuía uma casa assaz vistosa e ornamentada, escarrou-lhe na cara. Como este reagisse de mau talante, Diógenes disse: "Vejo que em toda a casa nada foi negligenciado ou ficou por ornamentar, a não ser tu: é que todas as paredes foram decoradas com excelentes pinturas, o pavimento foi recoberto com mosaicos de grande preço, o tecto foi trabalhado com admirável artifício; vejo também o leito e suas pernas belamente talhadas, as taças de ouro e prata sem mistura, mas dou-me conta de que tu, senhor de todas estas coisas, foste contaminado por toda a espécie de imundícies e misérias."37

Prouvera a Deus que por incúria dos progenitores não incorrêssemos numa tão grande fealdade de vida e numa tão grande ignorância! Na altura em que se devem abraçar os estudos das artes e das virtudes, permitem que os tenros corpos das crianças sejam corrompidos pelas delícias e pelos prazeres e todas as forças intelectuais enfraquecidas por uma educação frouxa. Razão pela qual com toda a justiça me parece digno de louvor aquele sapientíssimo Sólon por ter estabelecido uma lei para que ninguém fosse obrigado a sustentar e alimentar o seu pai, se este lhe não tivesse inculcado quaisquer conhecimentos e virtudes. ${ }^{38}$

Por aqui, nobilíssimos varões, podemos ver suficientemente o quanto o estudo das letras é preferível aos bens exteriores e fortuitos. Severino Boécio, o maior 
secum consideraret, seminarium quoddam disciplinarum omnium appellauit. Atque ut harum commendationem recto et suaui orationis ordine prosequar, olea quaedam nobis Mineruae, quae sapientia interpretatur, ob oculos constituenda est, e cuius pulcherrimis et ornatissimis ramis disciplinas omnes decerpamus.

[Grammatica] Igitur in primo huius arboris ramo nobis floret grammatica ${ }^{2}$, quae [7 $\mathbf{v}^{\mathbf{o}}$ ] omnium artium quae ad sermonis habitum pertinent, suo iure sibi primum locum uindicare potest. Hanc artem commendans apud Platonem, Socrates hoc ei imprimis laudis tribuit, quod mancam ac debilem futuram arbitratur omnem doctrinam quae grammaticae uiribus et quasi neruis suffulta ac solidata non fuerit. Vehementer enim ad intelligendas omnes alias artes et scientias conferre existimat, si et litterarum ratio et nominum uocumque doctrina, quae grammatica est, perfecte et ornate cognoscatur. Cui non parum assentitur M. Fabius Quintilianus, qui grammaticos scribit tantum in omni litteraturae genere nomen habuisse ut non modo poetarum, sed etiam scriptorum omnium iudices constituerentur. Nam et uersus censoria quadam uirgula notabant et libros, qui falso uiderentur inscripti, remouebant, auctores alios in ordinem redigebant, alios eximebant numero: inter quos fuit Aristarchus ille maximus huius artis splendor, qui de Homero et Pindaro prudentissimum et clarissimum iudicium fecit. Ac mihi quidem, in summas artes ac doctrinas intuenti, talis quaedam grammatica uideri solet ut sola possit, a reliquis separata, per se plurimum prodesse et delectare. Nec enim est ulla professio a qua tam frequentem et paratum fructum capiamus quam grammatica, nam de numeris, magnitudinibus, musicis et astrorum cursibus perraro quidem et quasi subsiciuis temporibus loquimur, at grammatica semper parata est, nullo loco excluditur, omni tempore nos adiuuat ac comitatur.

Non dico, uiri nobilissimi, ne uobis longior esse uidear, quae praemia, quae beneficia iure consulti optimi et sapientissimi uiri in eos conferunt qui in grammaticae doctrina excellentes exsistunt. Mitto Apollodorum huic facultati, sicut [8] nomen declarat, ab ipso Apolline datum, cui amphyctiones Graeciae amplissimam dignitatem concesserunt; mitto Antonium Gniphonem, ad cuius scholam M. Tullius post forensia negotia conferebat; mitto alios huius artis clarissimos doctores, quorum peramplum et illustre nomen satis nobis persuadet quam non modo summa cognitio, sed etiam diuinitas quaedam huic studio inesse uideatur. Quod certe uos multo magis credituros existimo, si artem hanc uideatis, praeter prima elementorum studia, alia quoque multo maiora, praestabiliora, meliora ac diuiniora poetarum et historicorum considerare.

\footnotetext{
${ }^{2}$ Grammatica deest in editione principe.
} 
lustre dos estudos liberais, ao ter plena consciência deste facto e ao ponderar no seu íntimo os seus bens, chamou-lhe uma espécie de viveiro de todas as ciências. ${ }^{39}$ E para prosseguir com correcto e harmonioso discurso o exalçamento destas, devemos como que colocar diante dos olhos a oliveira de Minerva, que simboliza a sabedoria, por forma a colhermos dos seus belíssimos e ornadíssimos ramos todas as ciências.

Portanto, no primeiro ramo desta árvore floresce a gramática, que com todo o direito $\left[\mathbf{7} \mathbf{v}^{\mathbf{o}}\right]$ pode reivindicar para si o primeiro lugar de todas as artes. ${ }^{41}$ Lê-se em Platão que Sócrates, fazendo o elogio desta arte, encarece-a antes de mais pelo facto de que em sua opinião há-de mostrar-se frágil e mutilado todo o ensinamento que não se achar consolidado e como que musculado com as forças da gramática. É que está vivamente convencido de que serve para compreender todas as outras artes e ciências, se se conhecer perfeita e elegantemente a disposição das letras e a ciência dos nomes e palavras, que é a gramática. ${ }^{42} \mathrm{Em}$ nada dele dissente M. Fábio Quintiliano, que escreveu que os gramáticos tiveram tamanho prestígio em todos os géneros de literatura que foram constituídos como juízes não só dos poetas, mas de todos os escritores. ${ }^{43}$ Com efeito, criticavam os versos e suprimiam os livros que parecessem falsamente atribuídos, e aos autores, a uns incluíam-nos no catálogo, a outros retiravam-nos do número das autoridades: entre estes contou-se o célebre Aristarco, glória máxima desta arte, o qual fez uma sagacíssima e claríssima avaliação crítica de Homero e Píndaro. E a mim, ao olhar para as artes e conhecimentos mais elevados, certamente que me costuma parecer que a gramática é de natureza tal que ela só, separada das restantes, pode ser de muito proveito e deleitação. É que não existe nenhum saber como a gramática do qual obtenhamos um proveito mais constante e prestimoso, porquanto a verdade é que de números, grandezas, música e cursos dos astros falamos mui raramente e como que em momentos de ócio, ao passo que a gramática está sempre prestes, não se exclui de nenhuma situação e acompanha-nos e ajuda-nos em todas as ocasiões.

Para que não vos pareça que sou prolixo, nobilíssimos varões, não refiro as distinções e benefícios que os melhores jurisconsultos e mais sábios varões atribuem aos que se mostram superiores no conhecimento da gramática. Deixo de lado Apolodoro, que, tal como [8] o nome indica, Apolo dotou para este saber, e ao qual os anfictiões da Grécia concederam a mais alta dignidade; deixo de lado António Gnífon, a cuja escola Marco Túlio se dirigia depois dos negócios forenses; ${ }^{44}$ deixo de lado outros ilustríssimos mestres desta arte, cujo renome abalizado e ilustre de sobejo nos persuade de como neste estudo parece residir não só o mais alto conhecimento, mas também uma espécie de divindade. Considero que haveis de dar muito mais crédito a isto, se desta arte, além dos primeiros estudos dos rudimentos, quiserdes examinar também outras coisas muito maiores, mais excelentes, melhores e divinas de poetas e historiadores.

E falemos em primeiro lugar dos poetas. O sapientíssimo Platão, sentindo admiração pela sua grandeza, musa e divina inspiração, não só designava os poetas como intérpretes dos deuses, como também dizia (algo que parece dificultoso de crer) 
Ac primum de poetis. Quorum cum numen, musam, diuinum furorem admiraretur sapientissimus Plato, poetas tum deorum interpretes appellabat, tum etiam (quod uix credendum uidetur) omnes scientias ac doctrinas in poetarum carminibus reperiri dicebat; cuius rei hoc signum erat, quod poetae ipsi, amoto iam furore, uix intellectu carminum uirtutem ac diuinitatem consequerentur. Quod cum ueteres sapientes non ignorarent, poeticen multo magis quam reliquas artes colendam censuerunt, quod intra eam seu commune quoddam receptaculum ceterae contineri uidentur, itaque non iam poeticen illam, sed primam quamdam philosophiam ac theologiam nominabant. Ac certe poetas Aristoteles scribit apud priscos et primos philosophos et theologos appellatos fuisse.

Quam magnam ac diuinam poeticae laudem in Mose, Dauide, Iob, Isaia ceterisque huius ordinis ac studii sanctissimis prophetis inuenire possumus, qui mihi illo ipso diuini numine, quo res sacras ac omni admiratione dignas decantarunt, afflati fuisse uidentur, ut metrum potius quam aliud sermonis genus ad decantandum inuenirent! De quibus $\left[\mathbf{8} \mathbf{v}^{\mathbf{o}}\right.$ ] diuus Hieronymus, in Eusebium, ait: "Quid psalterio suauius, quod Flacci et Pindari nunc iambico, nunc Sapphico pede fluens lyram refert? Quid Deuteronomii et Isaiae cantico pulchrius? Quid Salomone grauius? Quid Iob perfectius?” Quae omnia ab illis hexametris et pentametris carminibus composita fuerunt.

Quod poetas rerum suarum scriptores secum habuerit magnus ille Alexander facile ex Plutarcho et Cicerone nouimus. Atque is, cum Dario Persarum rege uita et imperio spoliato inter eius delicias cistellam quamdam auro gemmisque ornatam uidisset, uarios eius usus cum dicerent amici, iussit rex sapientissimus ut in ea magnum opus Homeri reponeretur. Sic enim delectabatur Homero, ut eius "Iliade", quam semper prae manibus habebat, saepius quam puluino uteretur. Idem etiam, cum Thaebas Boeotiae caput belli caperet, suis praecepisse dicitur ne Pindari poetae familiam et Penates attingerent.

Quid quod nobis declarat ipsa natura quam tum poetarum nomen colere et uenerari debeamus? Quae, cum "ceterarum rerum studia arte et praeceptis constent, poetam sua quasi manu effecerit et mentis uiribus", ut ait Cicero, "excitauerit." Quamobrem scribit Diodorus carmen non ingenio aut industria humana, sed diuino munere inuentum esse et Heliconiis musis datum. Non igitur est cur istas, quae uulgo iactari solent, poetarum accusatrices uoces audiendas putemus, poetas, cum nihil praeter inanes fabulas enarrent, non esse legendos.

Nam cur tam multa sermonis ornamenta, uitae praecepta, documenta, tantam exhortationum, sententiarum, delectationum copiam, quae in poetarum libris insita et sparsa est, non legemus ac repudiabimus? Cum praesertim 
que nas composições dos poetas se encontravam todas as ciências e conhecimentos: a prova disto encontrava-se no facto de que os próprios poetas, uma vez passada a inspiração, a duras penas conseguiam entender o sentido e perfeição dos seus poemas. ${ }^{45}$ Como os antigos sábios não desconheciam isto, pensaram que a poesia deveria ser muito mais cultivada do que as restantes artes, dado que as demais pareciam encerrar-se dentro dela como numa espécie de receptáculo comum e, por isso, designavam-na não já como poesia, mas como uma espécie de primeira filosofia e teologia. E é certo que Aristóteles escreveu que entre os antigos e mais primitivos se chamava aos poetas filósofos e teólogos.

Quão grande e divino merecimento de poesia não podemos encontrar em Moisés, David, Job, Isaías e nos demais santíssimos profetas desta condição e gosto, que me parece que foram inspirados por aquele mesmo divino poder, com que celebraram coisas santas e dignas de toda a veneração, de maneira a encontrarem para cantar a linguagem métrica de preferência a outra de género diferente! ${ }^{46}$ Acerca deles $\left[\mathbf{8} \mathbf{v}^{\mathbf{o}}\right.$ ] disse São Jerónimo, ao falar contra Eusébio: "Que há de mais suave do que o saltério, que restitui a lira de Flaco e de Píndaro, fluindo ora com o pé iâmbico, ora com o sáfico? Que existe de mais formoso do que o cantar do Deuteronómio e de Isaías? Que há de mais ponderado do que Salomão? Que há de mais perfeito do que Job?" ${ }^{47}$ Todos estes textos foram por eles compostos em poemas de seis e de cinco pés.

Por Plutarco e Cícero sabemos claramente que aquele célebre Alexandre Magno teve consigo poetas encarregados de escreverem as suas façanhas. ${ }^{48} \mathrm{O}$ qual, depois de haver privado da vida e do poder Dario rei dos Persas, viu entre os objectos de luxo que a este tinham pertencido um certo cofrezinho ornamentado com ouro e pedras preciosas; depois de os seus amigos lhe indicarem vários dos seus usos, o sapientíssimo rei ordenou que nela se colocasse a grande obra de Homero. ${ }^{49}$ É que de tal maneira se deleitava com Homero que mais amiúde se servia da Ilíada, que trazia sempre entre mãos, do que do travesseiro. ${ }^{50}$ Conta-se também que o mesmo Alexandre, depois de ter tomado na guerra Tebas, capital da Beócia, ordenou aos seus que não tocassem na família nem na casa do poeta Píndaro. ${ }^{51}$ Pois que dizer do facto de que a própria natureza nos mostra o grande dever que temos de respeitar e venerar o nome dos poetas? É que ela, enquanto "os estudos das demais coisas se fundam em arte e regras, como que criou por sua mão o poeta e”, consoante diz Cícero, "despertou-o com as forças do entendimento." 52 Por este motivo Diodoro escreve que a poesia não foi descoberta pela inteligência ou indústria humana, mas por mercê divina outorgada às musas do Hélicon. Por conseguinte, não há razão para pensarmos que se devem dar ouvidos a essas opiniões, que correntemente se propalam, em que se acusam os poetas e se afirma que se não devem ler porque nada mais contam senão fábulas vãs.

Ora, porque não havemos de ler ou havemos de rejeitar tão grande número de primores de linguagem, regras e exemplos de vida, e tamanha abundância de exortações, sentenças e coisas deleitáveis, que se encontram espalhadas e esparzidas 
Socrates apud Platonem non solum poetarum opera diuina ac diuino quodam oraculo edita appellet, sed etiam doceat ut in poetis uersantes [9] non tam carmina quam carminum sensa et intellectum consideremus. Quod satis confirmat Horatius ad Lollium scribens praecepta uitae pulchra et utilia ab Homero melius et plenius quam Chrysippo et Crantore expressa fuisse.

Nec solum poeticen ramo suo grammatica, sed historiam quoque complexa est. Ex qua praeter alias innumeras haec praecipue capitur utilitas, quod haec res maxime homines ad omnem laudem uirtutis incendere potest. Quid enim est quo possint ad uirtutem ardentius incitari, a turpitudinibus et uitiis acrius reuocari, nec periculis ullis aut incommodis perterreri quominus honesta et gloriosa facta imitentur, quam bonorum omnium uirtutem et malorum prauitatem in historiis, tamquam in scaenis publicis, manifeste repraesentari? Historia certe maximorum uirorum res et illustria facta ab interitu obliuionis liberat; historia, ut Ciceronis uerba commutem, temporum testimonium praestat, ueritatem illustrat, memoriam confirmat, uitam instruit, uetustatem nuntiat. Nec etiam ab hoc nomine abhorrent beatissimorum euangelistarum codices, quos "historiam euangelicam" communi sermone appellamus.

P. ille Mucius pontifex maximus, cum crederet nihil magis utile et necessarium hominibus et ciuitatibus esse posse quam res gestas litterarum monumentis tradi, praeclare et sapienter instituit ut singulorum annorum res in libros conferrentur, qui, a definito temporis spatio, "Annales" nominabantur.

Eiusque rei tabulam domi suae proposuit, ut esset omnibus potestas et copia cognoscendi, quod ignorare quid ante nos acciderit nihil aliud esse arbitrabatur quam nos perpetuo pueros esse, nec id iniuria, namque illos uiuere atque aetate frui non puto qui rerum anteactarum memoriam una cum aetate sua non contexunt: unde dixisse $\left[\mathbf{9} \mathbf{v}^{\mathbf{0}}\right]$ uidetur M. Fabius historiam nobis conferre ut quantum ad rerum notitiam attinet, praeteritis etiam saeculis uixisse uideamur.

Quid quod Aegyptii et Chaldaei summo ingenio homines in Republica instituerunt ut sacerdotes et philosophi in scribendis rerum historiis occuparentur? Denique tanta est historiae uis tantaque excellentia ut etiam puerorum animos et mentes in scholis delectet et ad laudis studia incendat.

Verum cum loquendi ratio per se non possit illum sermonis ornatum qui in copiosa, distincta et eleganti oratione cernitur efficere, doctrina quaedam nobis diuino numine concessa in secundo sapientiae ramo floret, quae a Graecis "Rhetorice", a Cicerone "artificiosa eloquentia" dicitur. Cuius cum tanta sit uis et potestas ut possit dicendo quae iusta, honesta et utilia sunt omnia auditoribus persuadere, merito eam atque optimo iure Sophocles, 
pelos livros dos poetas? E isto principalmente quando Sócrates, citado por Platão, não só proclama as obras dos poetas como divinas e produzidas por uma espécie de oráculo divino, mas igualmente aconselha os que lêem [9] os poetas a atentarmos não tanto nos versos quanto no sentido e significado dos mesmos. ${ }^{53}$ Horácio corrobora bastante esta opinião ao escrever a Lólio que as belas e úteis regras de vida foram mais perfeita e cabalmente expostas por Homero do que por Crisipo e Crantor. ${ }^{54}$

E a gramática abrange no seu ramo não só a poesia, mas também a história. Além de outras inúmeras utilidades que dela resultam, a principal é que ela pode incitar muitíssimo os homens a todos os merecimentos da virtude. De facto, que coisa os pode mais ardentemente impelir à virtude, mais vivamente apartar das baixezas e defeitos e a não deixarem que o temor de quaisquer perigos ou incomodidades os impeçam de imitar façanhas honrosas e gloriosas, do que nas histórias pôr-se claramente diante dos olhos, como nos teatros públicos, a virtude de todos os bons e a perversidade dos ruins? A história, como é sabido, liberta da morte do esquecimento as acções e feitos ilustres dos maiores varões e, parafraseando as palavras de Cícero, "dá testemunho dos tempos, ilumina a verdade, fortifica a memória, é mestra da vida e faz conhecer a antiguidade." ${ }^{5}$ E também não são incompatíveis com este nome os escritos dos bem-aventuradíssimos evangelistas, a que na linguagem corrente designamos como "história evangélica".

Aquele célebre pontífice máximo P. Múcio, porque acreditava que para os homens e para as cidades nada pode existir de mais útil e necessário do que consignarem-se por escrito as acções praticadas, estabeleceu com grande tino e acerto que se registassem em livros os acontecimentos de cada ano, a que davam o nome de Anais devido ao espaço de tempo que compreendiam. ${ }^{56} \mathrm{E}$ na sua casa tinha em exposição um quadro com este material, para que todos tivessem a possibilidade e ensejo de conhecer, pois pensava que ignorar o que aconteceu antes de nós não é senão conservarmo-nos sempre crianças, no que não deixava de ter razão, porquanto não creio que vivam e gozem da existência as pessoas que não unem estreitamente à sua vida a lembrança dos acontecimentos anteriores: motivo que parece $\left[9 \mathbf{v}^{\mathbf{0}}\right.$ ] que levou M. Fábio a dizer que a história nos é útil para quanto pertence ao conhecimento das coisas e também para como que vivermos nos séculos passados. ${ }^{57}$ Que dizer do facto de os Egípcios e os Caldeus, homens de avantajada inteligência, terem estabelecido que, na República, os sacerdotes e os filósofos se ocupassem em escrever a história dos acontecimentos? Por derradeiro, é tamanha a importância e tão grande a excelência da história que também deleita na escola o espírito e entendimento das crianças e as incita ao amor pela glória.

Mas como as regras do falar não são capazes por si mesmas de conceder aqueles atavios de linguagem que se vêem num discurso eloquente, bem ordenado e elegante, no segundo ramo da sabedoria floresce um saber, que a divina majestade nos ofereceu, e a que os Gregos chamam retórica e Cícero dá o nome de "artificiosa eloquência". É tamanha a sua eficácia e poder que, mediante a palavra, consegue persuadir aos ouvintes tudo o que é justo, honroso e útil, e foi com toda a justiça que Sófocles, 
tragoedias princeps, "et dominam et reginam rerum omnium" appellauit. Certe Plato eius diuinam uim aspiciens "inuentum Dei” nuncupat.

Nam, ut poetarum testimonium relinquamus, qui inuentum rhetoricae Mercurio deo attribuunt, quid nos excellentius, quid maius, quid diuinius eloquentia cogitare possumus? Quae nos a brutis animalibus, quae saepe uelocitate et uiribus corporis uincunt, separat; hominum coetus tenet, mentes allicit, uoluntates impellit quo uult, unde autem uult, deducit, turbas et seditiones populares comprimit, opem fert, excitat afflictos, dat salutem, liberat periculis, retinet homines in ciuitate, improbos et flagitiosos uituperando a flagitiis reuocat, bonos laudando paratiores et auidiores ad uirtutem facit, excitatos militum animos sedat, iratos temperat, perterritos metu liberat, in dubio positos confirmat, postremo, dat arma quibus et Reipublicae mala propulsentur et defendantur [10] bona.

Iulius ille Caesar, Romanorum primus imperator, cum uideret quantum non solum adiumentum, sed etiam ornamentum regibus et imperatoribus afferret eloquentia, ad eius studium ita incubuit ut nemini in dicendo cedens, quemadmodum ad Brutum scribit Cicero, permultos superauit. Certe bellicas ille laudes, quales ipse Cicero pro M. Marcello orans commemorauit, non minus eloquentia quam armis comparasse dicitur. Huius etiam heres Augustus, quo imperante res romana felicissima fuit, tantopere delectatus est eloquentiae studio ut bello Mutinensi, cum in tanta rerum mole et occupatione uersaretur, eius rei exercitationes, nunc legendo, nunc scribendo, nunc declamando numquam omiserit.

Quam uenusta et utilis sit eloquentia habemus apud Homerum optimum Vlixis exemplum, quem sua eloquentia et diis immortalibus gratum et hominibus acceptum et periculis uariis terraque marique liberatum fecit. Nec mediocrem etiam ad huius rei laudem materiam esse existimemus, quod hanc unam cunctarum rerum facultatem praestanti ingenio, perpetuo studio et plurimis disciplinis comparari oporteat. Quo audacius dicendum est perfectos philosophos, iureconsultos, imperatores, Reipublicae administratores esse non posse, nisi sese maxime in eloquentiae studio exercuerint. Quamobrem Themistoclem, Periclem, Theramenem, maximos et sapientissimos Graeciae duces, memoriae proditum est non prius se ad Reipublicae gubernationem conferre uoluisse quam singulari eloquentia et magnis dicendi uiribus armati fuissent. E quibus Pericles tam potens fuit ut fulgurare in dicendo suis uideretur.

Nec uos moueat, uiri nobilissimi, quod rhetoricen olim e ciuitatibus suis Lacedaemonii et Romani expulerunt. Quod illi populi tum [ $\left.\mathbf{1 0} \mathbf{v}^{\mathbf{o}}\right]$ effecerunt, cum nondum uberrimos et suauissimos rhetoricae fructus persentirent, quemadmodum solent multa egregia et utilia, antequam cognoscantur, contemni ac repudiari. Cum tamen paulatim huius rei et honestatem et utilitatem experirentur, tum demum eam non solum in 
príncipe da tragédia, lhe chamou "senhora e rainha de todas as coisas". ${ }^{58}$ E é certo que Platão, considerando a sua divina eficácia, a designa como "invenção de Deus".

De facto, e deixando de lado o testemunho dos poetas, que atribuem ao deus Mercúrio a invenção da retórica, ${ }^{59}$ que podemos imaginar de maior e de mais divino do que a eloquência? É ela que nos separa dos brutos animais, que frequentemente nos vencem em forças e velocidade; ela que mantém os homens unidos, atrai as inteligências, impele as vontade na direcção que pretende, as desvia de onde quer, contém as multidões e as sedições populares, dá socorro, alenta os atribulados, oferece a salvação, liberta dos perigos, mantém os homens na cidade, afasta, pela repreensão, os desonestos e infames das infâmias, torna, pelo louvor, os bons mais propensos e ávidos de virtude, aquieta o ânimo exaltado dos soldados, acalma os irados, livra de medo os assustados, fortalece os que hesitam e, ao cabo, proporciona armas para se afastarem os males e defenderem os [10] bens da república. ${ }^{60}$

Aquele célebre Júlio César, primeiro imperador dos Romanos, ao ter consciência da grande ajuda e ornamento que a eloquência significava para os reis e imperadores, de tal modo se aplicou ao seu estudo que, conforme escreve Cícero a Bruto, sem dar a ninguém a primazia na oratória, avantajou-se a muitos. ${ }^{61}$ Diz-se que ele obteve a glória militar, tal como a evocou Cícero ao falar em defesa de M. Marcelo, ${ }^{62}$ não menos graças à eloquência do que pelas armas. Também o seu herdeiro Augusto, durante cujo governo os negócios de Roma decorreram com a máxima prosperidade, sentia tanto prazer com o estudo da eloquência que, na guerra de Módena, embora se ocupasse e visse assoberbado por uma massa imensa de assuntos, nunca punha de parte o exercício desta actividade, ora lendo, ora escrevendo, ora declamando. ${ }^{63}$

De como a eloquência é formosa e útil temos em Homero o excelente exemplo de Ulisses, cuja eloquência o tornou grato aos deuses e aceito aos homens e o libertou de variados perigos em terra e no mar. E também não julguemos que é pequena matéria de louvor para esta actividade o facto de que, de todas as coisas, este é o único talento que, para se alcançar, requer uma inteligência superior, um estudo incessante e uma grande quantidade de conhecimentos. Por isso cumpre que se diga com toda a afoiteza que os filósofos, os jurisconsultos, os generais e os governantes do Estado não podem ser perfeitos se não se aplicarem muitíssimo ao estudo da eloquência. Por este motivo diz-se que Temístocles, Péricles e Terâmenes, os maiores e mais sábios dirigentes da Grécia, não quiseram consagrar-se à governação do Estado antes de se terem armado com uma extraordinária eloquência e com grandes recursos oratórios. ${ }^{64}$ De entre estes Péricles possuiu uma tão grande eloquência que, quando discursava, aos olhos dos seus parecia que lançava relâmpagos. ${ }^{65}$

Tão-pouco vos impressione, nobilíssimos varões, o facto de que outrora os Espartanos e os Romanos expulsaram a retórica das suas cidades. E estes povos procederam então $\left[\mathbf{1 0} \mathbf{v}^{\mathbf{o}}\right]$ desta maneira porque ainda não sentiam os riquíssimos e agradabilíssimos frutos da retórica, da mesma forma que é comum desprezarem-se e rejeitarem-se muitas coisas úteis e excelentes antes de serem conhecidas. Todavia, depois de aos poucos experimentarem a dignidade e utilidade deste saber, então 
Rempublicam suam admittendam, sed etiam summo studio et industria perdiscendam putarunt.

Dialectica Verum eloquentia, quamuis per se ornatissima et praestantissima facultas sit, quae possit de quacumque re proposita, ut apud Platonem iactat Leontinus Gorgias, apte et copiose dicere, tamen eam multo ornatiorem, praestantiorem et potentiorem putabo si, quemadmodum cum dialectica ramo coniuncta est, sic studio pariter et lucubratione coniungatur. Sine qua non modo nullam, qui reliquarum doctrinarum stadia percurrunt, metam contingere possunt, sed etiam in medio cursu claudicant atque deficiunt. Cuius quidem rei nos admonet Plato, qui a litterarum curriculo claudos et mancos omnes submouendos arbitratur.

Nam, quae ingenii claudicatio aut quae debilitas maior esse potest quam in rerum cognitione, quae in profundo puteo Democrito latere uisa est, sic uelle uersari ut non possis quae uera et quae falsa sunt cognoscere? Qui sunt qui rerum difficilia proposita tractare inuenire et iudicare possunt? - Dialectici. Qui sunt qui in omni studiorum genere palmam consequi possunt? - Dialectici. Qui sunt quibus aliarum rerum cognitio subiecta est? - Dialectici.

Inter multas et magnas commoditates quae ipso nobis quasi partu dialecticae cooriuntur, illam maximam putat Aristoteles, primus huius rei illustrator, quod, cum in inquirendo posita sit, facillimum et expeditissimum nobis ad omnium methodorum principia iter ostendit. Quare eius rudes qui reliquas disciplinas attingere [11] audent, persimiles illis uideri solent qui in obscuris tenebris aut infesta oculis caligine uersantur. Numquam, mehercle, ille ipse Aristoteles tantum laudis et gloriae in studio sapientiae meruisset nisi disserendi uitia omnia, quae in permultis philosophis animaduertit, procul a se remota reliquisset. Numquam Accursius ille uester - uobis loquor, iureconsulti - tantum nomen in iure ciuili consecutus fuisset nisi artem hanc, artium ceterarum lucernam, ad "obscurissimas ciuilium quaestionum tenebras”, ut ille appellat, adiunxisset.

Quid de ceteris sapientissimis hominibus dicam qui summam huius rei studio operam dederunt? Inter quos fuit ille Chrysippus Solensis in dialecticis tam excellens ut eius dialectica digna diis immortalibus, si disserendi ratione uti uellent, uisa fuerit.

Dialecticam Plato cum uideret in distinguendo, diuidendo, definiendo ac iudicando positam esse, necessariam ac utilem esse dicebat et ad interrogandum et ad respondendum.

Apud quem Socrates, dialecticam cum reliquis disciplinis conferens, ait: "Sed quominus his scientiis palmam concedendam putemus, una nos uetat dialectica, quae cum circa omnes res uera, falsa, antecedentia, consequentia omnia inueniat ac iudicet, arbitror omnes, qui ratione et iudicio utentur, eam ceterarum artium et optimam et praestantissimam esse habituros." 
consideraram que ela deveria não só ser acolhida no seu país, mas também aprendida com o máximo desvelo e aplicação.

Mas embora a eloquência seja por si mesma um talento muito notável e distintíssimo, Dialéctica que habilita a falar apropriada e copiosamente acerca de qualquer assunto proposto, como (consoante se lê em Platão) se jactava Górgias de Leontinos, ${ }^{66}$ todavia considerála-ei muito mais notável e poderosa se, tal como se encontra unida com a dialéctica no mesmo ramo, ${ }^{67}$ assim igualmente a ela se juntar mediante o estudo e o desvelo. Sem ela os que correm os estádios das demais ciências não só não podem alcançar qualquer meta, como também claudicam e falham a meio da carreira. Platão advertenos deste perigo, pois pensa que devem ser afastados da carreira das letras todos os coxos e mancos. ${ }^{68}$ De facto, que maior manqueira ou que maior debilidade de inteligência pode existir do que pretender alguém dedicar-se ao conhecimento das coisas, (que Demócrito achava que se encontrava escondido num poço muito fundo) em condições tais que é incapaz de reconhecer o que é verdadeiro e o que é falso? Quem são os homens capazes de examinar, descobrir e julgar as dificuldades dos assuntos que se lhes propõem? - Os dialécticos. Quem são os homens que podem obter a palma em toda a sorte de estudos? - Os dialécticos. Quem são os homens de quem depende o conhecimento das outras coisas? - Os dialécticos.

Aristóteles, primeiro mestre deste saber, entre as muitas e grandes utilidades que como que são parto da dialéctica, considera que a maior de todas é o facto de, uma vez que se funda na inquirição, nos mostrar um caminho muitíssimo fácil e expedito para os princípios de todos os métodos. ${ }^{69}$ Por isso, os que, ignorando-a, se atrevem a dedicar-se [11] às demais ciências, costumam parecer-se com as pessoas que se encontram nas trevas ou no meio de névoa cerrada que impede a visão. Por Deus, nunca esse mesmo Aristóteles teria merecido tantos louvores e glória no estudo da sabedoria se não tivesse ficado ileso de todos os vícios de raciocínio que censura em muitos filósofos. Nunca aquele vosso célebre Acúrsio ${ }^{70}$ - e estou a dirigir-me a vós, jurisconsultos - teria alcançado tamanho renome no direito civil se não tivesse aplicado esta arte, que é a lâmpada das restantes artes, às "trevas cerradíssimas" (é assim que as caracteriza) das questões civis. Que hei-de dizer acerca dos restantes homens que se entregaram com o máximo afinco ao estudo desta matéria? Entre estes celebrizou-se Crisipo de Solos, tão extraordinário nos estudos dialécticos que a sua dialéctica parecia digna dos deuses imortais, se quisessem servir-se de um método de raciocínio. ${ }^{71}$ Platão, porquanto se dava conta de que a dialéctica se funda nas distinções, nas divisões, nas definições e nos juízos, dizia que ela era útil e necessária tanto para perguntar como para responder. Lemos neste autor que Sócrates, comparando a dialéctica com os restantes saberes, diz: "Mas para impedir-nos de pensar que a palma deve ser outorgada a estas ciências, basta-nos somente o veto da dialéctica, a qual - uma vez que, relativamente a todas as coisas, destrinça na íntegra o verdadeiro, o falso, os antecedentes e os consequentes - suponho que todos que desfrutam de razão e discernimento crítico hão-de tê-la na conta da melhor e mais excelente das restantes artes." 72 
Diuum equidem Augustinum uideo, cum dialecticae uim et naturam ante oculos posuisset, sic de ea locutum: "Nulla scientia est aut facultas quae sola uiuam magistri uocem (ut aiunt) requirat nisi dialectica." Quid quod ipsa ratio, quam nobis summus ille Deus praecipuam dedit et qua nos belluis praestare uoluit, non tantas in nobis uires haberet nisi dialecticae auxilio $\left[\mathbf{1 1} \mathbf{v}^{\mathbf{o}}\right.$ ] confirmaretur?

Quocirca mihi maxime reprehendendi uidentur qui, nescio qua Tisiphone quibusue colubris exagitati, huius rei studium, quo etiam deos immortales delectari Platonici putabant, quasi taetrum, insuaue et inutile repudiandum putant. Quod non putarent profecto si in quam uarios errores et Epicurus ille et alii dialecticae contemptores inciderint non ignorarent.

Plura de dialectica dicerem nisi me, et defessum iam superiori triuio, et aliquo, ut uidetis, sudore perfusum, ad suum amoenissimum et uiridissimum ramum uocaret Arithmetica.

Quam Boethius Seuerinus principem tum ad suscipiendam, tum ad ingrediendam aliarum rerum rationem exsistere arbitratur; nec immerito, siquidem omnes artes quae ad studium sapientiae pertinent habent quoddam commune cum arithmetica commercium et quasi societate quadam illius fruuntur. Arithmetica certe Nicomachus, Pythagoreus sapiens, omnem humanam laudem minorem existimans, diuina eam commendatione prosecutus est, cum ait eius exemplar a Deo spectatum fuisse, qui omnia, quae in mundo constituta sunt, numero digesserit, composuerit, perfecerit; arithmeticam huius socii Pythagorei, sapientissimi uiri, tam infusam et immersam rebus omnibus esse crediderunt ut numeros omnium rerum principia posuerint, a quibus et bonorum genera et caelestium rerum ordines et animalium constitutiones proficiscerentur, ita ut sine numeris, quasi quodam diuino oraculo admoniti, nec Deum Optimum Maximum esse dicerent nec diuinos animos corporibus humanis adhiberi.

Arithmeticae horum princeps Pythagoras admiratione captus saepe dicere solebat: "Nescio quid diuinitatis [12] in numeris inuenio, quod nec oculis cerni, nec sensibus percipi, nec animo cogitari potest." De arithmetica Archytas, ille Tarentinus singulari sapientia uir, loquens ait: "Praeclare mihi uidentur studium et ingenium suum ad coniectandas rerum disciplinas contulisse nec tempus ullum aetatis suae ab ea re procul egisse qui, cum omnem uniuersitatis naturam partesque contemplarentur, arithmeticam et inuentam et apertam nobis reliquerunt."

In arithmetica non solum gradus quidam et quasi pontes constituti sunt per quos ad alias artes ascendamus, sed etiam ad communem usum uitae humanae quantum pertineat hinc facile perspici potest quod sola haec aut publicis aut priuatis in rebus sumptus annumerat, permutationum, emptionum, uenditionum, pactorum conuentorumque omnium rationes custodit. De 
Por mim, vejo Santo Agostinho, depois de ter mostrado a eficácia e natureza da dialéctica, falar assim acerca dela: "A dialéctica é a única ciência ou saber que exige a viva voz (como se costuma dizer) do mestre." Que dizer do facto de que a própria razão, que aquele supremo Deus nos deu superior e pela qual nos quis avantajar às bestas-feras, não teria em nós um poder tão grande se não fosse fortalecida com o auxílio $\left[\mathbf{1 1} \mathbf{v}^{\mathbf{o}}\right]$ da dialéctica? Parecem-me por isso muitíssimo censuráveis os que, alucinados por não sei que Tisífone, ${ }^{73}$ ou por que cobras das cabeleiras das Fúrias, consideram que deve ser rejeitado como odioso, desagradável e inútil o estudo desta matéria, com o qual pensavam os platónicos que até os deuses imortais se deleitavam. Certamente que não teriam esta opinião hostil se não desconhecessem a grande quantidade de variados erros em que caíram tanto Epicuro como os outros menosprezadores da dialéctica. ${ }^{74}$

Diria mais coisas acerca da dialéctica, se, por um lado, não estivesse já fatigado com o trívio que acabamos de percorrer e, como podeis ver, coberto de algum suor, e, por outro, a aritmética não me chamasse para o seu mui viçoso e ameno ramo.

Boécio Severino considera que ela detém a primazia tanto para encetar como para adiantar no conhecimento das outras matérias: e não sem razão, visto que todas as artes que dizem respeito ao estudo da sabedoria têm um certo trato comum com a aritmética e como que usufruem de uma espécie de união com ela. Nicómaco, sábio pitagórico, considerando que a aritmética está acima de todo o louvor humano, honrou-a com um título de recomendação divino, ao afirmar que o paradigma dela foi tido em conta por Deus, que distribuiu, ordenou e subordinou a medida tudo quanto foi posto no mundo; os confrades pitagóricos deste Nicómaco, varões sapientíssimos, acreditaram que a aritmética se encontrava tão introduzida e entranhada em todas as coisas que conceberam os números como princípios de todas as coisas, deles fazendo provir as espécies de bens, a disposição das coisas celestes e as compleições dos seres vivos, a tal ponto que, como que ensinados por uma espécie de inspiração divina, diziam que sem números nem existiria Deus Óptimo Máximo nem os corpos humanos receberiam espíritos divinos. ${ }^{75}$

Pitágoras, o mais importante de todos estes, tomado de admiração pela aritmética, costumava dizer amiúde: "Nos números encontro um não sei quê de divino, [12] que nem os olhos podem enxergar, nem os sentidos perceber, nem o espírito pensar." ${ }^{6}$ Falando acerca da aritmética, disse aquele célebre Arquitas de Tarento: "Julgo que foi gloriosamente que consagraram o estudo e a inteligência a adquirir o conhecimento das coisas e não gastaram um instante da sua vida apartados desta matéria aqueles homens que, depois de contemplarem toda a natureza do todo e as partes, descobriram e nos revelaram a aritmética."

A aritmética serve não só como uma espécie de degraus e pontes através dos quais nos é possível alçarmo-nos às demais artes, ${ }^{77}$ mas também podemos facilmente dar-nos conta da grande utilidade que tem para o trato da vida corrente se atentarmos no facto de que tanto nos negócios públicos como privados é ela exclusivamente que enumera os gastos e faz o cálculo dos câmbios, das compras, das vendas e de 
arithmetica quae qualiaque Plato dixerit tacitus nullo modo praeterire possum, qui non solum arithmeticum sapientissimum animal appellat, sed etiam arithmeticae studio sic animos hominum ad cognoscendi rationem et modum informari arbitratur ut eos, qui et ad discendum tardiores et ad excogitandum hebetiores esse uidebuntur, huius artis praeceptis iubeat erudiri. Quod non iussisset nisi arte hac et ingenium acui et memoriam ali et animum ad intelligendum promptiorem ac paratiorem fieri existimasset. Itaque nihil philosophos, nihil imperatores, nihil moderatores reipublicae magnum aut dignum laude posse efficere existimat a quibus arithmetica repudiata fuerit.

Annon iure in tragoediis Agamemnonem ut stultum a Palamede reprehensum putamus, quod numerandi studium neglexisset? Denique solam [12 $\mathbf{v}^{\mathbf{o}}$ ] arithmeticam Salomon sapientissimus inter artes et scientias liberales dignam censuit quae cum sapientia coniungeretur, cuius adeo in "Libro Sapientiae" uerba sunt: "Circunspexi atque animum adiunxi ut sapientiam et numerum scirem."

Sciens praetermitto quanta in numeris illis ternario, septenario, denario uirtus ac diuinitas latens sit meque ad huius germanam geometriam confero, e cuius ramo dici non potest quam perfectos et suaues fructus res aliae capiant. Haec est, ut quae eius dignitas et excellentia sit cognoscamus, omnium mathematicarum doctrinarum prima et praestantissima, a qua pariter auctore ipso eodem, quem modo nominaui, Archyta Tarentino, discendi ratio quaedam ac forma accipitur, ita ut res omnes, et faciles et difficiles, cognitu geometria instructi facile consequamur.

Quamobrem Plato ageometritos, quod inepti et imparati ad philosophandum uiderentur, edicto a gymnasii sui aditu prohibuit. Ac si nihil praestantius, ut ante dictum est, nihil diuinius animo a Deo accepimus, ob id certe plurimum geometriam expetere debemus, quae quoniam res omnes a sensibili materia separatas intellectu et ratione mentis considerat, animos nostros potest a rebus caducis et abiectis, quae sensibiles sunt, in miram et incredibilem diuinarum contemplationem inducere. Huius diuinae scientiae cum ignara esset tota Graecia, Thales Milesius ad Aegyptios, patres geometriae, se contulit, a quibus cum ipsam didicisset, in patriam magna cum gloria reportauit, iuuenisque ipse in huius rei studio et multa consecutus est et multa posteris scripta reliquit.

Iam uero si geometriae praemia consideremus, tanta sunt quanta uix queo dicere. Dicam tamen quod apud Flauium Iosephum scriptum est: Aegyptios olim ampliorem [13] uitae cursum a Deo accepisse quod geometriae et astrologiae studia colerent frequentissime. 
todos os contratos e acordos. Não posso de forma alguma passar em silêncio os importantes conceitos que Platão expendeu acerca da aritmética, pois não apenas chama ao aritmético o animal mais sábio, ${ }^{78}$ mas também julga que com o estudo da aritmética o espírito dos homens de tal maneira fica educado para os métodos e regras da aprendizagem que prescreve que, os que parecem ser mais tardos em aprender e de entendimento mais embotado, sejam instruídos nos preceitos desta arte. ${ }^{79}$ Certamente que não teria feito esta recomendação se não tivesse considerado que mediante esta arte não apenas a inteligência se aguça e a memória se fortifica, como igualmente o espírito se torna mais apto e aparelhado para compreender. ${ }^{80}$ E por isso acha que os filósofos, os generais e os governantes que tiverem rejeitado a aritmética não podem fazer seja o que for de grandioso ou digno de louvor. ${ }^{81}$

Porventura não consideramos que nas tragédias é com toda a justiça que Palamedes insulta Agamémnon de insensato, pelo facto de este ter desprezado o estudo do cálculo? ${ }^{82}$ Por derradeiro, $\left[\mathbf{1 2} \mathbf{v}^{\mathbf{o}}\right]$ o sapientíssimo Salomão considerou que, das artes e ciências liberais, a aritmética é a única digna de unir-se com a sabedoria; são precisamente as seguintes as suas palavras no Livro da Sabedoria: "Olhei em torno e prestei atenção para aprender a sabedoria e o número." ${ }^{83}$

Deixo deliberadamente de lado a grande virtude e divindade que se oculta nos números três, sete e dez ${ }^{84}$ e passo a ocupar-me da irmã desta, a geometria, sendo-nos impossível dizer quão perfeitos e doces são os frutos que as outras coisas colhem do ramo deste saber. Para nos inteirarmos de qual é a sua dignidade e superioridade, ela é a mais importante e primeira de todas as ciências matemáticas: a qual, segundo também o mesmo autor que há pouco referi, Arquitas de Tarento, nos fornece um certo método e forma de aprender, de tal maneira que, mediante a geometria, facilmente alcançamos o conhecimento de todas as coisas, tanto fáceis como difíceis. Razão pela qual Platão proibiu por regulamento a entrada na sua Academia aos que não soubessem geometria, porquanto pareciam inaptos e não preparados para o filosofar. ${ }^{85} \mathrm{E}$ se, tal como dissemos atrás, a coisa mais excelente e mais divina que recebemos de Deus foi o espírito, certamente por esse mesmo motivo devemos dedicar-nos muitíssimo à geometria, a qual, porque, através da inteligência e a razão, examina todas as coisas separadas da matéria sensível, pode desviar os nossos espíritos das coisas baixas e perecíveis, que são sensíveis, para a maravilhosa e admirável contemplação das divinas. ${ }^{86}$ Como a Grécia inteira não tinha conhecimento desta divina ciência, Tales de Mileto dirigiu-se para o Egipto para aprender com os seus habitantes, pais da geometria; depois de a aprender com eles, trouxe-a para a pátria com grande glória, e ele mesmo em jovem no estudo desta matéria não só adiantou muito, como também deixou muitos escritos aos pósteros. ${ }^{87}$

Além disso, se reparamos nas vantagens da geometria, elas são tantas que é difícil indicá-las. Todavia direi o que se pode ler em Flávio Josefo, ou seja, que antigamente Deus concedeu aos Egípcios [13] uma vida mais prolongada porque mui frequentemente cultivavam o estudo da geometria e da astronomia. ${ }^{88}$ Também aquele célebre sábio de Cirene, Aristipo, tendo-o lançado no litoral de Rodes o 
Et Aristippus ille Cyrenaicus sapiens, cum naui tempestatibus fracta ad Rhodiorum litus eiectus esset, animaduersis in litore geometricis figuris animo fiduciam capiens socios suos confirmauit, quod ad Graecos et sapientes, non barbaros et incultos uenissent itaque a Rhodiis et salutatus fuit et beneficiis multis cumulatus: quamobrem suis nuntiari iussit ut eas res sibi habendas curarent quae cum possessore in naufragio enatant.

Quod, si dignitatem geometriae quaerimus, eius certe studio summi uiri et maximi reges dediti fuerunt. Inter quos satis laudari debet Ptolemaeus, rex praestantissimus, qui meliorem et faciliorem aditum ad geometriam cupiens, ab Euclide mathematico percontatus est essetne aliqua ad geometriam "Elementis" suis breuior uia: respondit is, nulla regia uia aut calle geometriam esse contentam. Sin potentiam tanta est cum geometria coniuncta ut, praeter pondera et mensuras, quae propria sunt eius inuenta, magnifica templa aedificet, urbes magnas, arces munitas, domos, theatra, sepulcra, agrorum fines, ad quorum mensionem inuenta est, terminet, instrumenta bellica conficiat, situs regionum ad castra constituenda eligat, turmas dilatet easdemque contrahat, horarum, mensium, annorum et spatia et instrumenta inueniat.

In mundo etiam siue ad superiorem illam, siue ad inferiorem hanc regionem oculos coniiciamus, nihil est quod, ut optime Agrigentinus Empedocles philosophatus est, non coniungat atque conseruet geometrica concordia, disiungat atque dissipet discordia. Quid quod a geometria non solum praestantissimas animi uirtutes cuiusmodi sunt iustitia, temperantia, amicitia, sed etiam omnis corporis species et pulchritudo plurimum [ $\mathbf{1 3} \mathbf{v}^{\mathbf{o}}$ ] mutuatur? Nam et forma corporis in membrorum proportione et symmetria consistit, et multa saepe publicis, priuatis, domesticis et familiaribus in rebus geometrica aequalitate reguntur.

Musica Sed iam tempus postulare uidetur ut aliqua uestros animos, ex tanto rerum concursu, modulatione reficiam et aures, audiendo defessas, aliquo musicae concentu et suauitate recreem. Cuius ramum cum intueor, quanta, obsecro, in eo uoluptatis et eruditionis copia floret! Antiquis illis temporibus, cum studio cuique uera et perfecta laus tribuebatur, musicos homines et uates et sapientes nominatos accepimus fuisse. Atque ita res habebat ut qui artis musicae essent rudes, iidem ad omnia liberalia studia inepti et ignaui haberentur. Etenim musica cum sit dulcis, tranquilla, suauis, maxime potest humanos animos, lenitate perfusos, asperitate et perturbatione liberatos, ad tranquillum et quietum mentis et animi studium transferre. Tunc enim intelligentia nostra suum praestare potest officium, cum animus curis, ut ait Aristoteles, et cogitationibus uacuus et expeditus est.

Huius rei exemplum, omissis ueteribus lyricis, qui ad componenda carmina lyra et plectrum adhibebant, a regio Dei uate Dauide capere possumus, 
barco ao qual o temporal fez naufragar, recobrando confiança ao notar na praia figuras geométricas, encorajou os seus companheiros ao assegurar-lhes que tinham naufragado em terra de gente grega e civilizada, e não de bárbaros e incultos, e assim foi salvo e cumulado de muitas mercês pelos Ródios: razão pela qual mandou que se fizesse saber aos seus que tratassem de possuir aquelas coisas que, nos naufrágios, nadam juntamente com o seu possuidor. ${ }^{89}$

Por isso, se procuramos informar-nos acerca da dignidade da geometria, não há dúvida de que ao seu estudo se consagraram os varões mais insignes e os maiores reis. Entre estes deve louvar-se assaz Ptolomeu, notabilíssimo rei, o qual, desejando a melhor e mais fácil introdução à geometria, perguntou ao matemático Euclides se existia algum caminho mais breve para a geometria do que os seus Elementos: ao que este respondeu que a geometria não se encontra encerrada em nenhum atalho ou caminho real. Mas, quanto ao poder da geometria, ele é tão grande que, além dos pesos e medidas, que são descobertas específicas dela, edifica magníficos templos, grandes cidades, fortalezas, casas, teatros, túmulos, determina os limites dos campos, para cuja medição se inventou, fabrica material bélico, escolhe as posições para estabelecer os acampamentos militares, aumenta e diminui as unidades de combate e descobre a duração e instrumentos de medição das horas, meses e anos. ${ }^{90}$

Também no mundo, quer lancemos os olhos para aquela região superior, quer para esta inferior, não existe coisa que se una e conserve, ou se desuna e destrua, senão em conformidade com a harmonia, ou desarmonia, geométrica, tal como excelentemente filosofou o agrigentino Empédocles. ${ }^{91}$ Que dizer do facto de que da geometria não só derivam as mais excelentes virtudes da alma, como são a justiça, a temperança e a amizade, mas também a beleza e perfeição de todo o corpo? [13 $\mathbf{v}^{\mathbf{0}}$ ] Com efeito, por um lado, a forma do corpo funda-se na proporção e simetria dos membros, por outro, muitas coisas nos assuntos públicos, privados, domésticos e familiares regem-se amiúde pela igualdade geométrica. ${ }^{92}$

Mas o tempo já parece exigir que com alguma melodia vos alente os ânimos assoberbados por um tamanho acumular de matérias e, com a harmonia e suavidade da música, vos recreie os ouvidos cansados de escutar. Ao pôr os olhos no ramo dela, como é grande, santo Deus, a abundância que nele floresce de deleitação e de saber! Naqueles antigos tempos, quando se concedia a cada estudo o verdadeiro e perfeito louvor, temos notícia de que os músicos eram chamados homens sábios e poetas. ${ }^{93} \mathrm{E}$ a situação era tal que se consideravam como inaptos e incapazes para todos os estudos liberais os que ignoravam a arte da música. ${ }^{94}$ É que, visto que a música é doce, tranquila e suave, tem por isso uma imensa eficácia para, derramando a doçura nos espíritos humanos e libertando-os da rudeza e da inquietação, os colocar em estado de cultivarem tranquila e pacificamente o entendimento e o espírito. De facto, a nossa inteligência só pode cumprir a sua função quando o espírito está livre e desembaraçado de cuidados e cogitações, consoante diz Aristóteles. ${ }^{95}$

Deixando de parte os antigos líricos, que na composição dos poemas utilizavam a lira e o plectro, podemos ir buscar o exemplo deste facto a David, o régio poeta de 
quem scimus ad psalterium et citharam diuinas laudes decantasse. Pleni sunt libri, plenae historicorum uoces quantum musica apud saeculum prius summi reges et clarissimi imperatores delectati fuerint. Quibus, inter lautissima conuiuia et ornatissimos mensarum apparatus, nulli sapores nullaeque epulae suauiores et meliores esse uidebantur quam deorum immortalium ac magnorum heroum laudes ad citharam audire, quod non fecissent profecto nisi in musicis et uoluptatem et eruditionem summam [14] sitam credidissent. Huius illi cum et auribus sonum perciperent et harmoniam sensu notarent, uim et fructum animo consequebantur.

Nec uos latere puto, uiri noblissimi, quam laudatus fuerit Socrates sapientissimus, quod senex institui lyra non erubuerit, quam contra uituperatus et habitus indoctior Themistocles, Graeciae princeps, quod eamdem in epulis recusauerit. O laudandum illius factum, qui musicam senex senectutis suae leuamen, sapiens sapientiae telum, homo humanitatis munus tantopere expetiuerit; huius uituperandum, qui eam non sine magna auctoritatis amissione contempserit. Quid est enim aliud musicam contemnere nisi omnem prorsus humanitatem deponere? Imperitiam ostendere? Mundi denique ipsius compositionem, quae musica quaedam est, non contemplari?

Pythagoras, ille sagacis animi uir, cum caelestium sphaerarum interualla certa quadam proportione et mensura distincta considerasset, mundum eiusque partes omnes illa septem tonorum harmonia, quae diapason uocatur, constare dixit, magnumque ac suauem sonum, sensu nostro maiorem, orbes caelestes motu suo quotidie efficere. Quem Publius ille Cornelius Scipio percipiens apud Marcum Tullium, sic Aemilium patrem alloquitur: "Quis est hic, pater optime, quis est qui complet aures meas tantus et tam dulcis sonus?"

Quod, si musicae fructus magnus non esset, nec ex eius studio summa tum eruditio, tum delectatio animis humanis nasceretur, numquam profecto summi uiri eius studia tantopere coluissent, nec multa ac uaria ad modulandum instrumenta nobis inuenissent.

Quod illi tanto diligentius et suauius effecerunt quanto musicam ad res uel secundas uel aduersas aptiorem esse uidebant. Haec saxorum [14 $\mathbf{v}^{\mathbf{o}}$ ] duritiem, solitudinum asperitatem, nemorum densitatem percutit; huius audito sono, bestiae saepe immanes flectuntur ac, deposita feritate, mitescunt; hac uiperae uenenosae consistunt; huius lenitatem delphini sentiunt; hac ad bellum incitantur equi; haec omnes affectus animi aut suauitate remittit aut grauitate sua astringit; iram sedat, lasciuiam frangit, cupiditatem cohibet, tristitiam lenit, secundis rebus animum oblectat, aduersis solatur, tardum 
Deus, que sabemos que cantou os louvores divinos acompanhando-se do saltério e da cítara. Cheios estão os livros e cheios os discursos dos historiadores do quanto os reis mais importantes e os mais ilustres imperadores dos tempos antigos se deleitavam com a música. A eles, no meio dos banquetes mais ricos e do sumptuosíssimo aparato das mesas, parecia-lhes que nenhuns sabores nem nenhumas iguarias eram mais delicados e saborosos do que ouvir os louvores, acompanhados à cítara, dos deuses imortais e dos grandes heróis, algo que certamente não sucederia se não acreditassem que na música reside o supremo prazer e saber. [14] O seu espírito enriquecia-se com forças e frutos ao escutarem com os ouvidos o som dela e ao avaliarem com a razão a sua harmonia.

Penso, nobilíssimos varões, que não ignorais o quanto o sapientíssimo Sócrates foi louvado por em velho não sentir vergonha por aprender a tocar lira, e o quanto, pelo contrário, foi verberado e tido por mais ignorante Temístocles, líder da Grécia, por num banquete se ter recusado a tocá-la. ${ }^{96} \mathrm{Oh}$, quão louvável acção a do primeiro, que com tanto empenho procurou aprender a música, que a ele, como velho, era refrigério da velhice, como sábio, estímulo de sabedoria, como homem, ocupação da humanidade; quão repreensível o procedimento do segundo, ao desdenhá-la com grande descrédito de si mesmo. De facto, desprezar a música que outra coisa é senão dar de mão por inteiro a todos os sentimentos próprios do homem? Assoalhar a ignorância? E, por derradeiro, não enxergar a disposição do mundo, a qual mais não é do que uma espécie de música? Pitágoras, aquele célebre varão de espírito sagaz, depois de ter observado os intervalos das esferas celestes separados por uma certa proporção e medida, afirmou que o mundo e todas as suas partes assentam naquela harmonia de sete tons, a que se dá o nome de diapasão, e que os orbes celestes com o seu movimento todos os dias produzem um grande e suave som que os nossos sentidos não conseguem perceber. ${ }^{97}$ Tendo o célebre Públio Cornélio Cipião escutado este som, dirigiu-se (consoante se pode ler em Marco Túlio) nos seguintes termos ao seu pai Emílio: "Que som é este, meu querido pai, que som tão grande e tão doce é este que enche os meus ouvidos?"98

Pelo que, se os benefícios da música não fossem tão grandes, nem do seu estudo resultaria enorme saber e deleitação para os espíritos humanos, nem certamente jamais os varões mais eminentes teriam cultivado o seu estudo com tal intensidade, nem nos teriam descoberto muitos e variados instrumentos para tocar. Algo que estes homens realizaram com tanto maior diligência e agrado quanto maior era a consciência que tinham de que a música era mais adequada tanto para as situações de adversidade como para as de prosperidade. Ela abala e penetra a dureza das pedras, $\left[\mathbf{1 4} \mathbf{v}^{\mathbf{o}}\right]$ a aspereza dos ermos, a espessura dos bosques; depois de escutarem o seu som, os animais selvagens frequentemente se dobram e, pondo de parte a ferocidade, se amansam; ${ }^{99}$ com ela, as víboras peçonhentas imobilizam-se; os golfinhos são sensíveis à suavidade dela; ${ }^{100}$ ela incita os cavalos à peleja; ${ }^{101}$ ela, quer com a sua suavidade, quer com a sua gravidade, ora acalma, ora sujeita todas as paixões: extingue a ira, doma a sensualidade, refreia a cobiça, suaviza a tristeza, recreia o espírito na prosperidade 
ad labores, durum ad lenitatem, crudelem ad clementiam, iniustum ad iustitiam reducit; huic denique parent pueri recens nati, quos in incunabulis non modo, cum lugent, nutricis cantu lacrimas deponere, sed etiam somno capi cernimus: nulla enim parte facilius et melius quam auribus ad animum medicina penetrare potest.

Pythagoram, summum uirum, aiunt, cum uino tumultuque concitatum adulescentem uideret, nec precibus amicorum deflexum quominus riualis sui domum uellet incendere, mutare modum iussisse atque ita grauitate modi animum adulescentis in temperiem quamdam et consonantiam redegisse. Achillem etiam fortissimum scribit Homerus citharae suauitate, quam a Chirone praeceptore suo didicerat, animum saepe uicisse et iracundiam cohibuisse. Quin Saulis animum regius uates Dauid cithara sua saepe temperauit.

Quid illa, obsecro, quae Orpheo et Amphioni musicis a poetis attributa sunt, feras domitas, saxa pertracta, urbes cantu conditas significare putamus, nisi nullam esse tantam animi feritatem, nullam tantam reipublicae labem, quae musicae suauitate non mollescat atque reparetur? Quare non est cur Aegyptiorum factum probemus, qui musicam, quod ignauiam et animo mollitiem afferre uideatur, e republica sua eiecerunt. Plus apud me Lacedaemoniorum, qui bello praestantissimi fuerunt, consuetudo ualebit, qui, si animos hominum [15] infringi aut dispergi, ac non potius excitari ad proelium musica credidissent, numquam exercitus suos tibiarum cantu ad proelium parari uoluissent.

Quod idem fecisse Alyattem Lydorum regem memoriae traditum est, qui fistulatores et fidicinas ad bellum adhibuit. Quid quod funestis etiam rebus tibiarum cantus interponi consultum fuit? Credo ut suauitate cantus lugentium lacrimae excitarentur.

Astrologia Sed relicta musica, ad astrologiae iam, quae caelestis quaedam musica suo iure appellari potest, ramum accedamus. Cuius inuentum, ne nobis humana aliqua res uideretur, diis illis suis immortalibus ueteres attribuerunt. Equidem cum hominem ipsum considero eiusque animo excellentem ac diuinam naturam contemplor, ea lege natum fuisse existimo ut os sublime suum et diuinum animum ad caelum caelestiaque omnia suspicienda conferret.

Interrogatus summus ille Anaxagoras quam ob caussam se natum esse arbitraretur: "Vt caelum", respondit, "solemque ipsum uidendo contemplarer." Quam multos fuisse legimus grauissimos uiros, quorum summa ingenia cum labore in inspectione caelesti occupata fuerunt?

Floruit in astrologia apud Graecos Thales ipse Milesius, qui omnium primus non solum defectus solis et lunae rationem reperit, sed etiam 
e reconforta-o na adversidade, impele à actividade o remisso, à brandura o duro, à compaixão o cruel, à justiça o injusto; ${ }^{102}$ finalmente, a ela se submetem as crianças recém-nascidas, que vemos que não apenas deixam de chorar nos berços, mas também caem no sono graças aos cânticos das amas: é que os ouvidos são a melhor e mais expedita via que o remédio tem para penetrar no espírito.

Conta-se que o excelente varão Pitágoras, ao ver um moço perturbado pelo vinho e pelo desvairo, e que não se dobrava aos rogos dos amigos para que desistisse de pegar fogo à casa de um seu rival, ordenou que se mudasse o ritmo e desta forma, mediante a gravidade do ritmo, fez que o ânimo do moço recobrasse uma espécie de equilíbrio e harmonia. ${ }^{103}$ Também Homero escreve que o fortíssimo Aquiles amiudadas vezes domou o seu espírito e subjugou a ira mediante a suavidade da cítara que aprendera a tocar com o seu preceptor Quíron. ${ }^{104} \mathrm{E}$ o régio poeta David até frequentemente acalmou com a sua cítara o espírito de Saul. ${ }^{105}$

Que pensamos que significam, pergunto-vos, que pensamos que significam os feitos que os poetas atribuíram aos músicos Orfeu e Anfião de domarem feras, arrastarem atrás de si as pedras e fundarem cidades com o canto, ${ }^{106}$ senão que não existe nenhuma ferocidade de ânimo nem nenhum infortúnio público tão grandes que a suavidade da música não amanse e restaure? Pelo que não há razão para aprovarmos a decisão dos Egípcios, que desterraram da sua pátria a música com a alegação de que parecia ocasionar a frouxidão e apatia do ânimo. ${ }^{107}$ É muito mais do meu agrado o costume dos Lacedemónios, que foram inexcedíveis na guerra, os quais, se tivessem acreditado que a música [15] abate ou distrai o ânimo dos homens, ao invés de incitá-los à peleja, nunca teriam querido que os seus exércitos se aparelhassem para a batalha ao som das flautas. ${ }^{108}$ A mesma coisa, segundo se conta, fez Aliates, rei dos Lídios, o qual utilizou na guerra flautistas e tocadores de lira. ${ }^{109} \mathrm{E}$ que dizer do facto de que até nos momentos lutuosos foi costume intercalar-se a música das flautas? Creio que a fim de, com a suavidade da melodia, se provocarem as lágrimas dos enlutados.

Mas, deixando a música, aproximemo-nos já do ramo da astronomia, que com toda a justiça se pode designar como uma espécie de música celeste. Para que não nos parecesse ser alguma obra humana, os antigos atribuíram àqueles seus deuses imortais a descoberta desta ciência. Certamente que, quando considero o homem em si mesmo e medito na sua natureza superior e divina, penso que nasceu com características tais para aplicar a sua levantada cabeça e o seu espírito divino à contemplação do céu e de todas as coisas celestes. Perguntado aquele extraordinário Anaxágoras por que motivo achava que viera a este mundo, respondeu: "Para com a vista contemplar o céu e o próprio Sol." ${ }^{110}$ Consoante lemos, quão grande quantidade houve de varões prestigiosos cujas excepcionais inteligências se consagraram com o máximo desvelo a examinar o céu? Na astronomia, entre os Gregos destacou-se Tales de Mileto, que foi o primeiro de todos não só a descobrir os eclipses do Sol e a teoria da Lua, mas também predizia os mesmos eclipses antes que se dessem; ${ }^{111}$ destacou-se Pitágoras, que foi o primeiro a conhecer a natureza de Vénus e a observar 
defectus ipsos, antequam euenirent, futuros praedicebat; floruit Pythagoras, cui primo Veneris natura cognita est eiusque tum progressus, tum regressus sub sole considerati; floruit Endymion ille poetarum carminibus celebratus, cuius opera effectum est ut uniuersam lunae multiformitatem, crementum, decrementum, sinus, maculas, defectum, uelocitatem, tarditatem, ascensum, descensum, uim denique ipsam, qua inferiora haec participant, perfecte cognosceremus; floruit Ptolemaeus ille, quem $\left[\mathbf{1 5} \mathbf{v}^{\mathbf{o}}\right.$ ] ante commemoraui, Alexandriae rex, quem ad hoc studium diuino numine natum dicere fas est, qui caelum diu suspiciendo, siderum motus contemplando earumque rerum omnium rationes disquirendo, praeclara nobis sideralis scientiae uolumina scripta reliquit: quem etiam dicere solitum accepimus astronomi sapientia in hominum uita multa mala, quae futura sunt, remoueri, bona comparari posse; floruit Prometheus, qui sese ad montem Caucasum contulit ut, in eo alligatus, astrorum motus uiasque omnes intueretur; floruerunt alii etiam sapientissimi uiri, quos omnes in hac caelesti disciplina, - quae peritissimorum hominum iudicio contemplatio quaedam est -, sic elaborasse legimus ut nihil in ea tam difficile, nihil tam occultum, nihil tam secretum quod non diligentia ac studio facile apertum, clarum nobis reliquissent.

Certe Platonem Atheniensem uideo, cupiditate astrologiae incensum, non modo uniuersam Aegyptum, sed etiam Italiam peragrasse ut cum sacerdotibus Aegyptiis et Pythagoreis numeros et caelestia omnia conferret.

Quod idem aliquot ante annos fecisse dicitur Pythagoras, qui et Aegyptios et Persarum magos propter astrologiam adiuit. Cuius rei studium Plato tantum tamque supra uulgares ingenii uires positum esse arbitrabatur, ut illud diceret non posse nisi acutissimis et clarissimis ingeniis tractari. In quam sententiam a sapientissimo Socrate illud "quod supra nos, nihil ad nos" dictum existimare debemus.

Quomodo etiam terra, ut astrologiae commoda narremus, uberiores fructus procrearet? Quomodo medicina humano corpori oportuno tempore et conuenienti adhiberetur? Quomodo mercatorum nauigatio exerceretur atque earum rerum quae communis utilitatis caussa exportantur uectura fieret? Quomodo annorum, mensium, dierum, horarum distinctio cognosceretur, nisi haec siderum temperatione et astrologiae legibus [16] gubernarentur?

Possum hoc loco dicere magnos et fortes animos propter astrologiae imperitiam metu saepe perturbatos fuisse. Nicias, ille Atheniensium imperator, cum, defectu lunae perterritus, classem de portu educere uereretur, suorum opes afflixit et exercitum paene omnem in Sicilia labefactauit. Paulus Aemilius, Scipionis pater, nullam de Perse, Macedoniae rege, uictoriam, 
tanto os seus avanços como os seus retrocessos debaixo do Sol; ${ }^{112}$ destacou-se Endimião, celebrado pelas composições dos poetas, ${ }^{113}$ por obra do qual se logrou que chegássemos ao perfeito conhecimento da cabal multiplicidade de formas da Lua, seu crescimento, seu decrescimento, suas sinuosidades, suas manchas, seu eclipse, sua velocidade, seu retardamento, sua ascensão, sua descida e, finalmente, a própria força com que actua sobre estas coisas situadas mais abaixo; ${ }^{114}$ destacou-se aquele célebre Ptolomeu, a quem já atrás $\left[\mathbf{1 5} \mathbf{v}^{\mathbf{0}}\right]$ me referi, rei de Alexandria, de quem é lícito dizer que nasceu para estes estudos por vontade divina, o qual, entregando-se durante muito tempo à contemplação do céu, observando os movimentos dos astros e investigando o sistema de todas estas coisas, deixou escritos admiráveis volumes de ciência astronómica: ${ }^{115}$ sabemos também que ele costumava dizer que, mediante a sabedoria do astrónomo, é possível apartarem-se da existência humana muitos males que estão para acontecer e alcançarem-se muitos bens; destacou-se Prometeu, que se dirigiu para o monte Cáucaso, a fim de, amarrado a ele, observar todos os movimentos e órbitas dos astros; ${ }^{116}$ igualmente se destacaram outros varões muitíssimo sábios, os quais todos, segundo lemos, de tal maneira se aplicaram a esta ciência celeste - a qual, na opinião dos homens mais entendidos, é uma espécie de contemplação - que nela não houve qualquer ponto tão dificultoso, tão oculto e tão secreto que, mediante a sua diligência e aplicação, não nos tivessem deixado esclarecido, descoberto e claro.

Também vejo que o ateniense Platão, abrasado no desejo de conhecer a astronomia, percorreu não só todo o Egipto, mas também a Itália, a fim de discutir os números e todos os assuntos astronómicos com os sacerdotes egípcios e com os pitagóricos. ${ }^{117}$ Diz-se que alguns anos antes fizera o mesmo Pitágoras, que por causa da astronomia visitou os magos egípcios e da Pérsia. ${ }^{118}$ Platão considerava que o estudo desta matéria era tão importante e estava colocado tão acima das capacidades correntes da inteligência que dizia que não podia ser abordado senão por inteligências muitíssimo perspicazes e brilhantes. Devemos considerar que foi com este sentido que o sapientíssimo Sócrates pronunciou aquelas palavras: "o que está acima de nós não pertence à nossa alçada."119

Também, e a fim de enunciarmos os proveitos da astronomia: de que maneira a terra produziria maior abundância de frutos? De que maneira os remédios se aplicariam ao corpo humano na altura oportuna e conveniente? De que maneira se realizaria a navegação dos comerciantes e se faria o transporte daqueles produtos que se exportam tendo em vista a utilidade comum? De que maneira se saberia fazer a distinção dos anos, dos meses, dos dias e das horas: se todas estas coisas não fossem governadas [16] pela combinação dos astros e pelas leis da astronomia? ${ }^{120}$

Posso também lembrar aqui que espíritos superiores e valentes muitas vezes foram inquietados pelo medo devido à ignorância da astronomia. Aquele célebre general ateniense Nícias, como, apavorado por um eclipse da Lua, teve escrúpulo em fazer sair a esquadra do porto, arruinou o poderio dos seus e levou à destruição de quase todo o exército na Sicília. ${ }^{121}$ Paulo Emílio, pai de Cipião, não teria alcançado 
nullum triumphum reportasset, nisi suorum militum animos, eclipsis metu sollicitos, per C. Sulpicium liberatos recuperasset, qui, in contionem perductus, multa de utriusque sideris defectu sapienter et iucunde disputauit. Taceo de Pericle atque Beroso, peritissimis astrologis, quorum alter Athenienses eclipsi confusos sedauit, alter diuina multa praemonuit, ob quod publice in gymnasio statuam inaurata lingua meruit.

Quid quod non solum nos astrologia docet, quo modo siderum cursus et stellarum inter se affectiones cognoscamus, sed etiam quo pacto animos ac mentes nostras a terrenis et caducis rebus ad caelestium et aeternarum contemplationem deducamus? Quod sentiens, diuinus Plato eos ait sibi astronomi nomine indignos uideri qui, dum superna et caelestia suspiciunt, nihil in caelo ipso quod altius, sublimius ac diuinius sit speculentur, sicut nec musicos perfectos appellat qui sese ipso uocis concentu et exteriori harmonia ad interiorem animi consonantiam non composuerint: tantum in hoc astrologiae studio suauitatis et doctrinae situm est.

Multa pratereo sciens quae uobis cuperem enarrare, nisi me cum temporis angustia, cui subseruire sapientis est, tum uestrae defatigationis suspicio ab instituto orationis cursu retardaret.

Quare quae restant breuius et festinatius dicam quam res tanta dici possit. Ac primum me superiori mathematicarum rerum quadriuio satis defessum, medicinae ramo inumbrare uolo.

Medicina Quae, quoniam corpus hoc terreum, mortale, debile, caducum, quo compositi sumus, in uarios saepe morbos et languores $\left[\mathbf{1 6} \mathbf{v}^{\mathbf{o}}\right]$ incidit, diuina nobis liberalitate concessa fuit ut non modo quae ad eius curationem pertinerent, cum aegrotum est, remedia suppeditaret, sed etiam sanum aduersus periculosos ictus et incertos euentus ualetudinis accommodato regimine tueretur.

Quamobrem multi medicinam instaurandae et defendendae sanitatis artem, alii salubrium et insalubrium et neutrorum scientiam definierunt. Magnas cum Apollo ille Pythius nostrae mortalitatis miserias et communis naturae fragilitatem consideraret, medicinam inuenit; quam deinde eius filius Aesculapius non modo auxit, sed et hominibus tradidit, quapropter eum stulta antiquitas deorum numero ascripsit templaque et alia celebria loca dicauit. Eoque magis quod propter inauditam in medendo scientiam et incredibilem industriam existimatus est homines ad uitam artificio hoc reuocasse.

Quanta autem uis medicina sit quantaque fructuositas hinc maxime perspicere possumus quod, cum e communi sensu uitae humanae, Aesculapio ictu fulminis interempto, sublata fuisset, miseri et calamitosi homines, tantae 
nenhuma vitória nem nenhum triunfo sobre Perses, rei da Macedónia, se não tivesse devolvido o ânimo aos seus soldados, que o perderam com o medo dos eclipses e o recuperaram graças à intervenção de C. Sulpício, o qual, induzido a discursar, dissertou sábia e agradavelmente acerca dos eclipses do Sol e da Lua. ${ }^{122}$ Passo por alto Péricles e Beroso, astrónomos muitíssimo entendidos, o primeiro dos quais tranquilizou os Atenienses assustados com um eclipse, ${ }^{123}$ enquanto o segundo predisse muitas coisas extraordinárias, razão pela qual mereceu que lhe levantassem publicamente no ginásio uma estátua com língua dourada. ${ }^{124}$

E que dizer do facto de que a astronomia não só nos ensina como conhecermos a órbita dos astros e a influência que as estrelas têm umas sobre as outras, mas também a maneira de retirarmos os nossos espíritos das coisas perecíveis e terrenas para aplicá-los à contemplação das celestiais e eternas? Consciente deste facto, o divino Platão disse que considera indignos do título de astrónomos os homens que, ao contemplarem as coisas celestes e do alto, não enxergam no próprio céu nada que seja mais elevado, mais sublime e mais divino, ${ }^{125}$ tal como nega a designação de músicos perfeitos aos que não ajustarem a afinação da voz da harmonia externa à consonância interior do espírito: ${ }^{126}$ tamanha é a quantidade de prazer e saber que se encerra neste estudo da astronomia.

Deliberadamente deixo de lado muitas coisas que vos desejaria referir, se não me atalhasse à extensão que inicialmente dera ao meu discurso, por um lado a estreiteza de tempo, que é próprio do sábio acatar, e, por outro, a suspeita do vosso cansaço. Pelo que, aquilo que falta, expô-lo-ei mais breve e rapidamente do que é possível expor-se uma matéria tão importante. E, em primeiro lugar, assaz fatigado com o precedente quadrívio das matérias matemáticas, pretendo acolher-me à sombra do ramo da medicina.

Esta, porque este corpo de terra, mortal, frágil e perecível com que fomos feitos Medicina [16 $\mathbf{v}^{\mathbf{o}}$ ] cai amiúde em diversas enfermidades e fraquezas, esta foi-nos concedida pela divina liberalidade para que, não só quando ele está doente lhe fornecer os remédios acomodados à sua cura, mas também prevenir o são contra os riscos e incertas eventualidades mediante um regime saudável apropriado. Por este motivo muitos definiram a medicina como a arte de restaurar e defender a saúde, ao passo que outros a caracterizam como a ciência do saudável, do insalubre e do indiferente. ${ }^{127}$ O célebre Apolo de Delfos descobriu a medicina ao atentar nos grandes infortúnios da nossa mortalidade e na debilidade da natureza corrente; depois, o seu filho Esculápio não apenas a fez crescer, como também a ensinou aos homens como protecção, motivo pelo qual a estulta antiguidade o incluiu no número dos deuses e lhe consagrou templos e outros locais de culto. ${ }^{128} \mathrm{E}$ tanto mais porque devido ao seu excepcional saber terapêutico e ao seu extraordinário zelo se considerou que com esta arte ressuscitou pessoas.

Ora, quão grande seja o poder da medicina e quão grandes os seus benefícios é algo que podemos ver com a máxima clareza a partir do facto de que, tendo sido ela suprimida do trato corrente da existência humana depois que Esculápio foi morto pelo golpe de um raio, ${ }^{129}$ os mofinos e desgraçados homens, desprovidos de uma 
opis indigentes, cum miseriam, cum fragilitatem humanam, cum denique uitam ipsam suam tot tantisque infirmitatum et dolorum insidiis obiectum contemplarentur, seque uel acino uuae passae, ut Anacreon poeta, uel exhausto pilo, ut Fabius senator, uel musculae morsu interire posse non dubitarent, deorum oracula adibant, templa frequentabant, aruspicum responsa consulebant, medicinam tantorum malorum praesidium obnixe petentes. Tum demum eam e tenebris, in quibus quingentos fere annos latuerat, et densissima nocte Hippocrates Coüs, medicorum omnium facile princeps, in lucem reduxit praeceptisque et arte illustrauit.

Quod si herbarum uires, si aeris temperiem, si regionum situs, [17] si brutorum etiam quorumdam sollertiam in quaerendis remediis ante oculos ponimus, iure optimo huius artis naturam et procreatricem et magistram appellare possumus. Etenim his rebus natura ingenuit atque impressit semina medendi, quorum cum quaedam salubria, quaedam insalubria notassent homines, ex eo artem effecerunt.

Sed tamen, cum in uobis adhuc tanta attentio sit, tanta ad me audiendum uoluntas, augeamus sane huius rei laudem, simul enim augebimus et studium. Nam quis, obsecro, uestrum est, quos ego certo scio in omni studiorum genere ac rerum ueterum lectione noctes diesque uersari, qui non intelligat summos olim et grauissimos uiros in hoc studio maxime floruisse? Podalirium et Machaona, illo ipso Aesculapio genitos, quos egregie et magnifice carminibus suis laudauit Homerus, Asclepiadem, Chirona, Chrysippum, Galenum Pergamenum, Hippocratis tantum interpretem, aliosque complures quos longum esset nominare, in arte medendi clarissimos, quibus tantum laudis et honoris attulit medicina ut eos quidem ueteres non tam cum summis uiris comparandos quam ut deos exstructis templis colendos existimarint. Sic igitur diis simillimi inuentores et professores medicinae habiti sunt caeloque dicati.

Iam si praemia medicinae considerare uelimus, tum multo magis nobis compertum intellectumque fuerit quantum ea non modo laudanda, sed etiam expetenda uideri debeat. Nam et Hippocratem ferunt, cum pestilentiae aduentum praedixisset et auxiliatum discipulos ad urbes dimisisset, ob meritum tantum eosdem honores quos Hercules ab uniuersa Graecia accepisse, et Erasistratum, Aristotelis ex filia nepotem, cum Antiochum regem in aduersa ualetudine sanasset, a rege Ptolemaeo eius filio centum talentis $\left[\mathbf{1 7} \mathbf{v}^{\mathbf{o}}\right]$ donatum fuisse, et Quintum Stertinium principibus imputasse quod quingena HS tantum pro annuo salario darent.

Praetereo illos medicos celeberrimos quos Plinius Secundus commemorat, Cassios, Carpitanos, Arruntios, Albucios, Rubrios, qui CCL HS constitutam 
tão grande ajuda, como viam a desgraça, como viam a fraqueza humana e, ao cabo, como viam a sua própria vida sujeita a tão grande número e a tamanhos laços de enfermidades e dores, e não duvidavam de que podiam morrer ou por causa de um bago de uva passa, como o poeta Anacreonte, ou devido a um pêlo engolido, como o senador Fábio, ${ }^{130}$ ou em consequência da picadela de um mosquito, recorriam aos oráculos dos deuses, frequentavam os templos e consultavam as respostas dos arúspices, suplicando obstinadamente a medicina como socorro para tão grandes males. Só então Hipócrates de Cós, indiscutível patriarca de todos os médicos, a arrancou das trevas e densíssima noite em que se ocultara durante cerca de quinhentos anos, abrilhantando-a com regras e conhecimentos técnicos.

Pelo que, se atentamos nas propriedades das ervas, na temperatura do ar, na situação das terras ${ }^{131}$ [17] e até na esperteza de certos animais em procurar os remédios, com toda a justiça podemos designar a natureza desta arte como procriadora e mestra. É que a natureza fez nascer e imprimiu nestas coisas princípios curativos, dos quais os homens descobriram que uns são salutares e outros nocivos, fazendo deste conhecimento uma arte.

Mas todavia, uma vez que ainda estais tão atentos e possuídos de um tamanho desejo de escutar-me, encareçamos sem rebuço o louvor desta matéria, pois estaremos simultaneamente a encarecer também o seu estudo. De facto, há alguém entre vós, pergunto, vós que eu sei seguramente que aplicais os dias e as noites em toda a espécie de estudos e na leitura das coisas antigas, que não saiba que outrora os mais eminentes e sábios varões se notabilizaram sobretudo neste estudo? A saber, Podalírio e Macáon, filhos daquele mesmo Esculápio, a quem Homero egrégia e magnificamente louvou nos seus poemas, ${ }^{132}$ Asclépio, ${ }^{133}$ Quíron, ${ }^{134}$ Crisipo, ${ }^{135}$ Galeno de Pérgamo, tão importante comentador de Hipócrates, e inúmeros outros que seria fastidioso nomear, muitíssimo notáveis na arte de curar, aos quais a medicina ocasionou tamanho louvor e honra que os antigos pensavam que eles não deveriam ser comparados com os varões mais eminentes, mas antes adorados como deuses em templos edificados em sua honra. ${ }^{136}$ Por conseguinte, deste modo os descobridores e mestres da medicina foram tidos por totalmente semelhantes aos deuses e elevados ao céu. ${ }^{137}$

E se, por outro lado, quisermos considerar as vantagens da medicina, tornar-se-nos-á muito mais evidente e compreensível o quanto ela parece não só que deve ser louvada, mas também desejada. Na verdade, conta-se que Hipócrates, tendo predito a chegada da peste e enviado para as cidades os seus discípulos para prestarem ajuda, em paga de tão grandes serviços recebeu de toda a Grécia as mesmas honras que Hércules, como também se conta que Erasístrato, neto de Aristóteles por parte da filha, porque curou o rei Antíoco de uma doença, foi premiado com cem talentos pelo filho deste, o rei Ptolomeu, ${ }^{138}\left[\mathbf{1 7} \mathbf{v}^{\mathbf{o}}\right]$ e também que Quinto Estertínio censurou os governantes por só pagarem quinhentos sestércios como salário anual. ${ }^{139}$

Deixo de parte aqueles médicos muitos célebres que Plínio Secundo evoca, os Cássios, os Carpitanos, os Arrúncios, os Albúcios e os Rúbrios, aos quais os governantes estabeleceram um salário de 250 sestércios. ${ }^{140}$ Deixo de parte aquelas 
mercedem apud principes habuerunt. Praetereo illa munera, illos honores quos Iustinianus in medicos, in eorum uxores et liberos edictis suis contulit. Iuris Quod si huius philosophiae ramum, quae corporis tantum adiutrix et Disciplina conseruatrix est, tantis commodis et honoribus plenum uidemus, quid ab ea philosophia capere possumus, quae animum curat, mores componit et bene uiuendi rationem continet? Hanc cum Socrates sapientissimus et ad constitutionem et ad conseruationem humanae societatis plurimum pertinere posse arbitraretur, omnes cogitationes suas posuit, nullis se laboribus fregit nec uigiliis et curis uictus est ut philosophiam a rebus occultis ad studia morum et uitae praecepta reuocaret. Huius Socraticae philosophiae est alumna atque in eius ramo pulcherrime floret iuris disciplina, quam certe nominare multi possunt, colere et commendare pauci. Hanc enim non praetorum uox, non iure consultorum responsio non XII Tabularum scriptura, sed ea philosophia peperit quam uulgo moralis dicitur. Etenim si a uobis quaererem, a uobis, inquam, patres conscripti, quos in ciuili facultate florentissimos et prudentissimos esse uideo, quam existimationem aut sententiam de tam singulari scientia habeatis, illud nimirum mihi responderetis rerum diuinarum et humanarum esse cognitionem, societatis humanae uinculum, urbium et ciuitatum parentem, iustitiae et aequitatis, quae sunt lampades reipublicae, facultatem.

Fingite nunc animo ac uobiscum considerate nullam esse apud homines iuris [18] doctrinam, nulla legum sanctarum et morum praecepta: quid, obsecro, de rebus humanis fieret? Quo in statu aut ordine uita hominum consisteret? Quae essent uincula aut frena, quibus cupiditates, iniuriae, caedes, rapinae coercerentur? Quis non in uim, in tela, in insidias latronum passim, sine ulla spe salutis suae expediendae, incideret? Quae regia potestas dominaretur? Quae domus tam secura maneret in quam quotidie impetus ac irruptiones libidinis, audaciae, impietatis libere et impune non fierent? Quis intelligit haec qui non merito a Platone iuris disciplinam diuinum munus appellatum fuisse existimet? Certe Aristoteles, admirabili sapientia uir, artium omnium et facultatum quae ad Reipublicae utilitatem pertinent, reginam et principem appellauit.

Quae, quanto gratius nihil atque acceptius in terris illi principi Deo fieri potest quam ciuitates iure sociari, tanto diligentius nobis colenda et expetenda est, siquidem leges optima et firmissima tela Reipublicae peperit. Quarum imperio cum omnia tam publicis quam priuatis in rebus sapientissimi homines teneri uiderent, legem ausi sunt uocare aeternum quiddam uniuersum mundum regens, imperandi prohibendique sapientiam habens. Chrysippus tum diuinarum humanarumque rerum notitiam, tum etiam recti iussionem prauique depulsionem appellat. 
mercês e aquelas dignidades que por decretos seus Justiniano concedeu aos médicos e às mulheres e filhos destes. ${ }^{141}$

Ora, se vemos o ramo desta filosofia, ${ }^{142}$ que é uma tão grande auxiliar e conservadora do corpo, cheio de tamanhos proveitos e honrarias: que podemos Ciências colher destoutra filosofia que cura o espírito, regula os costumes e encerra em si a ciência de bem viver? ${ }^{243}$ O sapientíssimo Sócrates, porque pensava que ela podia ter muitíssimo a ver com o estabelecimento e conservação da sociedade humana, endereçou todos os seus pensamentos, e não se esquivou a nenhuns trabalhos nem houve vigílias e cuidados que o vencessem, no empenho de deslocar a filosofia dos temas secretos para o estudo dos costumes e das directivas para a vida. ${ }^{144}$ Desta filosofia socrática são alunas e no seu ramo formosamente florescem as ciências jurídicas: são certamente muitos os que podem nomeá-las, mas poucos os capazes de honrá-las e fazer-lhes o encómio. É que quem as deu à luz não foram as sentenças dos pretores, nem as respostas dos jurisconsultos, nem o texto das Doze Tábuas, mas aquela espécie de filosofia que vulgarmente se designa por "moral". ${ }^{145}$ Com efeito, se vos perguntar, a vós, membros do senado académico que sei que sois muitíssimo aproveitados e sábios no direito civil, qual é a opinião e parecer que tendes acerca de uma ciência tão extraordinária, sem dúvida respondereis que ela é o conhecimento das coisas divinas e humanas, ${ }^{146}$ o vínculo da sociedade humana, a progenitora das cidades e Estados e a faculdade da justiça e da equidade, que são os fachos da república.

Figurai-vos agora e imaginai que entre os homens não existia nenhum [18] conhecimento do direito, nenhuns preceitos de leis santas e de costumes; pergunto-vos: que sucederia à humanidade? Em que ordem ou estabilidade se fundaria a existência dos homens? Quais seriam os freios ou ataduras com que reprimir as ambições, as injustiças, os assassínios e as pilhagens? Quem não estaria sujeito por todos os lados à violência, aos golpes e às emboscadas dos ladrões, sem qualquer esperança de lograr a sua salvação? Qual o poder régio capaz de exercer a soberania? Qual a casa que se manteria de tal modo segura que todos os dias sobre ela, livre e impunemente, não se fizessem as arremetidas e ataques da sensualidade, do atrevimento e da impiedade? ${ }^{147}$ Dos que disto estão cientes, haverá alguém que não considere que foi com toda a justiça que Platão designou por "dádiva divina" as ciências jurídicas? Quanto a Aristóteles, varão de admirável sabedoria, chamou-lhes rainhas e princesas de todas as artes e talentos que dizem respeito à utilidade do Estado.

A estas ciências, assim como na terra nada se pode fazer que seja mais grato e mais aceito àquele soberano Deus do que ligar os Estados mediante os vínculos do direito, assim nos cabe a obrigação de tanto mais diligentemente as cultivar e procurar, visto que deram à luz as leis, as melhores e mais firmes armas da república. Os homens mais sábios, ao verem que era o senhorio destas que mantinha todas as coisas, tanto públicas quanto privadas, ousaram chamar à lei algo de eterno que rege a totalidade do mundo e que possui a sabedoria de ordenar e de proibir. ${ }^{148}$ Crisipo chama-lhe não apenas conhecimento das coisas divinas e humanas, mas também 
Pindarus hominum diuumque reginam ait esse, quod nihil tam iustum, tam sacrum, tam pium, tam religiosum esse possit quod hominum audacia non uiolet atque euertat penitus nisi legis habenis cohiberetur: legem idcirco gladium Reipublicae uocauit diuinus Plato quo Hydrae capita, hoc est, ea quae in commerciis et conciliis hominum crudeliter, libidinose, auide, impie, malitiose fiunt, amputari possint.

Nec aliam ob causam poetas finxisse carminibus suis arbitror tantarum rerum auctores non homines, sed deos exstitisse nihil quod in $\left[\mathbf{1 8} \mathbf{v}^{\mathbf{o}}\right]$ legibus diuinum quiddam inesse putarent, quo uniuersae gentes et populi gubernarentur, beatae et bene moratae Respublicae fierent.

Videte nunc, patres conscripti, ac pro magnitudine sapientiae et prudentiae uestrae statuite quantum summis illis philosophis debeamus, qui nobis non turbulentam aut seditiosam, ut uulgus imperitum existimat, Reipublicae concitatricem, sed moderatricem et conseruatricem iuris prudentiam inueniendam curarunt. Etenim digni sunt, nec id sine auctoribus loquor, quorum laudem cum maximorum imperatorum rebus gestis adaequandam putemus. Testes sunt Athenae, quam ciuitatem non minus Solon consiliis quam Themistocles armis et uictoria Salamina adiuuit. Testis Sparte, cuius si Pausanias et Lysander imperium bello dilatarunt, Rempublicam certe Lycurgus legibus ornatam et florentem fecit. Testis Creta insula, quam Minos rex aeque legibus ac armis defendit. Testis Roma totius orbis terrarum caput, cui nisi Numa Pompilius leges tradidisset, senatum Romulus constituisset, senatus exercitus magnos delegisset, non illud a Vergilio poeta decantatum "Romanos dominos" legeremus.

Non igitur minus iureconsultorum prudentiam Reipublicae quam imperatorum arma prodesse putemus. Quod cum intelligeret Flauius Iustinianus, iurisperitos qui defensionis suae uiribus incertum statum reipublicae componunt, lapsum erigunt, fatigatum reparant, cum illis comparandos putat a quibus patriae salus proeliis et uulneribus defenditur. Vtinam tantum mihi spatium temporis tributum et concessum esse uiderem quantum exopto, ut uobis hodie quae de pulcherrima hac et ornatissima facultate mente animoque concipio omnia uerbis enarrarem.

Theologia Illam Plato felicissimam atque optimam rempublicam appellabat in qua non temeritate aut imprudentia, quae concordiae aduersantur, sed ratione et consilio legum ciuilium omnia gererentur. Quid nos? Quanto feliciorem [19] et meliorem Christianam rempublicam appellare debemus, quae illis legibus constituta et fundata est, quas non a Solone Athenienses, non a Lycurgo Lacedaemonii, non a Numa Pompilio Romani, non a Pythagora Samio Itali, non a Mercurio Tertio Aegyptii, non a Phoroneo rege Argiui, sed nos ab ipso immenso et aeterno Deo, totius uniuersi Domino, accepimus, 
imperativo do recto e repulsa do ruim. ${ }^{149}$ Píndaro diz que é rainha dos homens e das divindades, ${ }^{150}$ porque não poderia existir coisa tão justa, tão sagrada, tão piedosa e tão venerável que o atrevimento dos homens a não violasse e destruísse por completo, se não fosse reprimido pelos freios da lei, ${ }^{151}$ razão pela qual o divino Platão chamou à lei espada do Estado, com a qual se podem decepar as cabeças da Hidra, isto é, tudo quanto nas relações e ajuntamentos dos homens se pratica de modo cruel, apaixonado, ávido, ímpio e malicioso. ${ }^{152} \mathrm{E}$ penso que o motivo que levou os poetas a imaginarem nos seus poemas que os autores de coisas tão grandes não tinham sido homens, mas deuses, não foi outro senão o pensarem que nas leis [18 $\mathbf{v}^{\mathbf{o}}$ ] existia algo de divino, com o qual se governariam os povos e nações e os Estados se tornariam afortunados e bem morigerados.

Vede agora, membros do senado académico, e, de acordo com a vossa grande sabedoria e prudência, avaliai o quanto devemos àqueles mais eminentes filósofos, que se ocuparam em encontrar para nós uma jurisprudência que fosse, não sediciosa ou turbulenta, consoante imagina o vulgo ignorante, e inquietadora do Estado, mas moderadora e conservadora do mesmo. Efectivamente, e não o afirmo sem fiadores, são merecedores de que reputemos o seu merecimento como comparável às façanhas dos maiores generais. É testemunha Atenas, cidade à qual não menos ajudaram Sólon com os seus conselhos que Temístocles com as armas e a vitória de Salamina. É testemunha Esparta, a qual, se cresceu em senhorio graças às guerras promovidas por Pausânias e Lisandro, certamente se tornou um Estado próspero e notável mercê das leis de Licurgo. É testemunha a ilha de Creta, que o rei Minos defendeu por igual com as leis e com as armas. É testemunha Roma, cabeça da Terra inteira, à qual, se Numa Pompílio não lhe tivesse dado leis, nem Rómulo estabelecido senado, nem o senado recrutado grandes exércitos, não poderíamos aplicar aquelas célebres palavras cantadas pelo poeta Virgílio: "Os Romanos, senhores do mundo."153

Por consequência, assentemos que as ciências jurídicas não são menos prestimosas ao Estado do que as armas dos generais. Porque o compreendeu, Flávio Justiniano pensa que os juristas, que com a energia da sua defesa conseguem a estabilidade do Estado, quando incerto, ou o levantam, quando decaído, ou lhe restauram as forças, quando debilitado, devem ser comparados com aqueles que asseguram a salvação da pátria mediante pelejas e ferimentos. ${ }^{154}$ Oxalá eu visse que me tinha sido atribuído e concedido tanto espaço de tempo quanto eu desejo para vos referir hoje tudo o que penso e sinto acerca desta formosíssima e distintíssima faculdade.

Platão chamava a mais afortunada e excelente das repúblicas aquela na qual Teologia todas as coisas fossem governadas, não pelo desatino ou a imprudência, que se opõem à concórdia, mas pela norma e a decisão das leis civis. ${ }^{155}$ E que havemos de dizer nós? Quanto mais afortunada [19] e mais excelente não devemos chamar a república cristã, que foi estabelecida e construída com tais leis que nós recebemos, não de Sólon como os Atenienses, nem de Licurgo como os Espartanos, nem de Numa Pompílio como os Romanos, nem de Pitágoras de Samos como os Ítalos, nem de Mercúrio Trismegisto como os Egípcios, nem do rei Foroneu como os Argivos, 
ut, si earum imperio, quo certe nihil leuius suauiusque amantibus esse potest, parere uoluerimus, non solum in terris hic magnam concordiam et tranquillitatem in animis nostris sentiamus, sed etiam post discessum a corpore sempiterna illa gloria perfruamur. Huius principis ac supremae legis doctrina in medio illo arboris aureo ramo, cui ceteri circumpositi ac demissi tamquam proprio imperatori obsequuntur.

De qua cum cogito eiusque laudem omnibus humani ingenii uiribus longe maiorem esse intelligo, uere in animum induco meum satius esse tacere quam de re tanta pauca dicere. Verum tacere, summe Deus, ac non tantarum laudum saltem aliquam umbellam uerbis consequi, uereor ne impietati ac negligentiae mihi attribuatur.

Te igitur obsecro tuamque eximiam clementiam imploro, cui nihil magis proprium ac conueniens est quam infirma hominum ingenia confirmare, ut mihi hoc loco praesidio et adiumento sis.

Theologiae, patres conscripti, quae summa ac perfectissima ueritatis contemplatio est, nomen sic accipere debemus ut illud non a poetica fabulatrice, quam ueteres caeci ignarique rerum falso theologiam appellabant, non ab illa, quam naturali quadam ratione et mentis acumine consequi putabant, philosophorum contemplatione, sed a uera atque a Deo ipso tradita doctrina profectum esse credamus. Huius nos diuinae scientiae nisi Deum ipsum doctorem habuissemus, nullam ne minimam quidem litteram intelligeremus.

Verum ipse, genus hominum prospiciens in tantis erroribus ita uersatum ut, ignorato uero ac perfecto Deo, a quo salus [19 $\mathbf{v}^{\mathbf{o}}$ ] et uita proficiscitur, inania et conficta idolorum simulacra ueneraretur, oblata iam temporis occasione quo misericordiae suae munere uteretur, filium suum in terras mittere non dubitauit ut esset is a quo studium hoc ueritatis, quae theologia dicitur, acciperemus.

Haec est diuina sapientia, cuius studio qui delectantur eos non solum recte et beate uiuere, sed etiam illam superorum uitam, cum adhuc in terris manent, imitari putamus.

Huic contemplationi ueritatis cum antiqui illi philosophi omnes suas curas et cogitationes accommodarent, nihil non modo, quod uerum et perfectum esset, intelligebant, sed etiam, ignorationem suam palam confitentes, nihil in rebus humanis cognosci, nihil percipi, nihil sciri existimabant: in qua sententia primus Socrates fuit, quem, hercle, non possum non maxime laudare qui, quasi huius diuinae scientiae - in qua nulla tenebris circumfusa, sed uera omnia et luce illustrata continentur - effigiem animo conciperet, nihil ille affirmabat, sed id unum se tantum scire profitebatur, quod sciret se nihil scire.

Haec est profecto cui, si omnis humana sapientia comparetur, non solum sapientiae nomen amittit, sed etiam stultitia uocatur. Hanc cum rex 
mas do próprio imenso e eterno Deus, Senhor de todo o universo, para que, se quisermos obedecer ao senhorio delas, que para os que amam é indubitavelmente a coisa mais leve e mais suave que existe, não só sintamos nos nossos espíritos aqui na terra uma grande concórdia e tranquilidade, mas também gozemos daquela sempiterna glória após o abandono do corpo.

Os ensinamentos desta principal e suprema lei florescem naquele ramo de ouro que está no meio da árvore, ao qual os restantes colocados em torno e por baixo reverenciam como a próprio amo e senhor. Quando penso acerca destes ensinamentos e compreendo que o seu louvor é de longe maior que todos os recursos da inteligência humana, deveras me convenço de que é preferível calar a ser escasso ao falar de uma matéria tão grandiosa. Mas, Deus santíssimo, receio que se me atribua a impiedade e negligência o calar e não fazer ao menos um pequeno bosquejo de tamanhos merecimentos. Por conseguinte, rogo-Te e peço à Tua imensa misericórdia, à qual nada é mais apropriado e ajustado do que fortalecer as fracas inteligências humanas, que neste lugar me prestes ajuda e socorro.

Membros do senado académico, o nome de teologia, que é a mais alta e mais perfeita contemplação da verdade, devemos tomá-lo de forma tal que creiamos que proveio, não da mistificação poética, a que os cegos e ignorantes antigos falsamente chamavam teologia das coisas, nem daquela contemplação dos filósofos, ${ }^{156}$ que pensavam alcançar através de uma certa razão natural e da penetração intelectual, mas da doutrina verdadeira e ensinada pelo próprio Deus. Se o nosso mestre desta divina ciência não tivesse sido o próprio Deus, dela não entenderíamos nem sequer a mais pequena letra. Mas Ele, vendo o género humano enleado por tão grandes erros, de tal maneira que, ignorando o verdadeiro e perfeito Deus, do qual provém a salvação [19 $\mathbf{v}^{\circ}$ ] e a vida, venerava vãos e fingidos simulacros de ídolos, apresentando-se já o momento oportuno em que usaria da mercê da Sua misericórdia, não hesitou em enviar à terra o Seu filho, para que dele recebêssemos este estudo da verdade, a que se dá o nome de teologia. ${ }^{157}$

Esta é a divina sabedoria: cremos que os que se deleitam com o seu estudo não só vivem recta e afortunadamente, mas também imitam, ainda durante a sua permanência na terra, aquela vida dos seres celestiais. Os antigos filósofos, embora aplicassem todos os seus cuidados e pensamentos a esta contemplação da verdade, não só não compreendiam o que era a verdade e a perfeição, como também, reconhecendo abertamente a sua ignorância, consideravam que nas coisas humanas era impossível conhecer-se, perceber-se ou saber-se fosse o que fosse. ${ }^{158} \mathrm{O}$ primeiro a professar esta opinião foi Sócrates, a quem, por Deus, não posso deixar de louvar sobremaneira, porque ele, como se concebesse no espírito a imagem desta divina ciência - na qual nada se encontra rodeado de trevas, mas, alumiado pela luz, nela se encerra tudo quanto é verdadeiro - nada afirmava, mas confessava que apenas sabia que sabia que nada sabia. ${ }^{159}$

Realmente, esta é a ciência que, se a ela se compara toda a sabedoria humana, esta não só perde o nome de sabedoria, mas até ganha a designação de loucura. 
ille Ptolemaeus admirabili rerum diuinarum magnitudine et excellentia circumsaeptam consideraret, ne attingendam quidem esse censuit theologiam, quod eam nemo pro exiguitate humani ingenii comprehendere ac concipere posse uideretur: nec immerito, siquidem hanc de Deo cognitionem cum inuestigare conaretur Simonides ille poeta, in hanc uocem prorumpit: "Quanto magis magisque cogito, tanto mihi res difficilior et obscurior esse uidetur." De hac contemplans Pythagoras ille Samius, nihil aptius et conuenientius ad studium pietatis et religionis esse dicebat quam rerum diuinarum scientiae operam dare.

O diuinam sapientiam, quae manifeste Deum nobis demonstrat, per quam Christvm Seruatorem nostrum, ex beata Virgine [20] natum, intelligimus! O excellentem ueritatis cognitionem, quae omnem sacrosanctae Scripturae ueritatem patefacit, figuram interpretatur mysteriaque omnia explanat, qua quidem uel rustici homines instructi summis illis excellentissimisque philosophis sapientiores et beatiores efficiuntur! O primam ac summam philosophiam, cui certe si reliquas artes et scientias comparemus, satis amplae ac ornatae nobis uideri debent, quod ei quasi diuino numine famulentur!

Haec habui, patres conscripti, quae uobis, quantum per ingenii mei exiguitatem et negotiorum occupationem licuit, de doctrinarum commendatione dicerem, quarum studia cum iam in nostra Lusitania consumpta essent, ea certe diuus Ioannis, huius nominis tertius, rex diuina beneficentia nobis concessus, non modo ab interitu reuocauit, sed etiam amplissima et ornatissima effecit. Cuius etiam insignes et admirabiles uirtutes, nisi uos audiendo iam defessos uiderem, ea dicendi copia enarrarem quam tantus rex ac regum omnium facile princeps requirit. Nam quem Alexandrum liberaliorem (ut ueterum exempla usurpem), quem Caesarem fortiorem, quem Numam religiosorem, quem Traianum aequiorem hoc nostro rege antiquis illis temporibus fuisse accepimus? Cuius ut ingenium, quod ei felicissimum datum est, ut liberalitatem, qua non solum in suos, sed etiam in omnes totius orbis terrarum homines frequentissime utitur, ut imperium, cui totum fere orbem terrarum subiectum habet, praetermittam: illam certe multo maiorem iis et ampliorem laudem praetermittere non possum quam communi hominum consensu consecutus est, quod academiam hanc, omnium quae in toto terrarum orbe sunt florentissimam, constituit, in quam sapientissimos et grauissimos doctores ex omni fere Europa conuocauit, ut praeclara Lusitanorum suorum ingenia sanctissimis etiam litteris exornaret, quae paratissima ad militandi scientiam habuisset.

Quid igitur restat, adulescentes optimi? Quid reliquum est nisi ut $\left[\mathbf{2 0} \mathbf{v}^{\mathbf{o}}\right]$ et inuictissimo serenissimoque regi nostro bene precemur et litterarum studia, quae nos possunt facere et seruare beatos, manibus pedibusque obnixe sequamur: quod certe nos diligentius et accuratius facturos putabo si, et illud a Seneca philosopho dictum ante oculos posuerimus "uita 
Como o célebre rei Ptolomeu a observasse, rodeada pela admirável grandeza e excelência das coisas divinas, afirmou que a teologia nem sequer devia ser tocada, porque parecia que ninguém podia abarcá-la e concebê-la devido às limitações da inteligência humana: ${ }^{160}$ e não sem razão, visto que, tendo-se o conhecido poeta Simónides esforçado em alcançar este conhecimento de Deus, prorrompeu neste brado: "Quanto mais e mais penso, tanto mais difícil e obscuro este assunto me parece." 161 Reflectindo sobre ele, Pitágoras de Samos dizia que nada era mais acomodado e apropriado para o zelo da piedade e da religião do que aplicarmo-nos à ciência das coisas divinas.

Oh divina sabedoria, que claramente nos mostra a Deus e através da qual compreendemos a Cristo nosso Salvador, nascido da bem-aventurada Virgem! [20] Oh excelente conhecimento, que patenteia toda a verdade da sacrossanta Escritura, interpreta as figuras simbólicas e explica todos os mistérios, instruídos pela qual até os homens ignorantes se tornam mais sábios e mais felizes do que os mais eminentes e mais extraordinários filósofos! Oh primeira e suprema filosofia! Se com ela compararmos as restantes artes e ciências, certamente que nos devem parecer muitíssimo importantes e honradas porque, por assentimento divino, a servem como escravas. ${ }^{162}$

Membros do senado académico, era isto o que, na medida em que o permitiram a exiguidade das minhas capacidades intelectuais e os encargos dos meus negócios privados, tinha a dizer-vos em abono das ciências, cujo estudo, que já se encontrava amortecido no nosso Portugal, o admirável D. João, terceiro deste nome, rei a nós concedido pela bondade divina, não só ressuscitou da morte, como também o ampliou e ilustrou sobremaneira ${ }^{163}$ Se já não vos visse fatigados de ouvir, também vos descreveria as insignes e admiráveis virtudes deste rei com aquela eloquência que exige um tamanho monarca e indubitavelmente o primaz de todos os reis. De facto, para nos servirmos de exemplos dos antigos, temos notícia de que naqueles antigos tempos houve algum Alexandre mais liberal, algum César mais valente, algum Numa mais religioso ou algum Trajano mais equitativo do que este nosso rei? Para não me referir à sua inteligência, com que foi excepcionalmente favorecido, à sua liberalidade, de que mui amiúde usa não apenas com os seus, mas com os homens do mundo inteiro, e ao seu poder, sob o qual mantém quase a Terra inteira: certamente não posso deixar de me referir a um motivo de louvor, muito maior e mais glorioso do que estes, e que alcançou por consenso comum dos homens por ter fundado esta academia, a mais florescente de todas as que existem no mundo, ${ }^{164}$ para a qual chamou os mais sábios e mais prestigiados mestres de quase toda a Europa, a fim de também munir com as santíssimas letras as brilhantes inteligências dos seus portugueses, que encontrara muito bem preparadas para a ciência da guerra. ${ }^{165}$

Ora, que nos falta, ó escol da mocidade? Que nos resta senão $\left[\mathbf{2 0} \mathbf{v}^{\mathbf{0}}\right]$ desejar o bem para o nosso invictíssimo e sereníssimo rei e obstinadamente e com todas as nossas energias prosseguirmos o estudo das letras, que nos podem fazer e manter felizes: algo que não tenho quaisquer dúvidas em pensar que nós havemos de realizar mais diligente e escrupulosamente se, por um lado, pusermos diante 
sine litteris mors est et uiui hominis sepultura", et nullorum tam beatam tamque hominibus - propter quos nos natos esse stoici arbitrabantur commodam uitam esse duxerimus quam eorum qui in optimo, sanctissimo, fructuosissimo, ornatissimo, suauissimo (quid plura dicam?) litterarum studio uersantur.

DIXI 
dos olhos aquele célebre dito de Séneca, de que "a vida sem letras é a morte e sepultura de um homem vivo", ${ }^{166}$ e, por outro lado, crermos que nenhuma vida é tão bem-aventurada e tão vantajosa para os homens - por causa dos quais, segundo pensavam os Estóicos, nós tínhamos nascido ${ }^{167}$ - do que a daqueles que se ocupam com o excelente, santíssimo, utilíssimo, honrosíssimo e suavíssimo (porque hei-de dizer mais?) estudo das letras. ${ }^{168}$

DISSE 